\title{
Gadolinium-Based Contrast Agents Targeted to Amyloid Aggregates for the Early Diagnosis of Alzheimer's Disease by MRI
}

Guillaume Bort, ${ }^{a *}$ Sarah Catoen, ${ }^{b}$ Hélène Borderies, ${ }^{a}$ Adel Kebsi, ${ }^{a}$ Sébastien Ballet, ${ }^{b}$ Gaëlle Louin, ${ }^{b}$ Marc Port, ${ }^{b}$ Clotilde Ferroud ${ }^{a}$

${ }^{a}$ Conservatoire national des arts et métiers, ERL 3193 Cnrs, 2 rue Conté, 75003 Paris, France.

${ }^{\mathrm{b}}$ Guerbet, Centre de Recherche, BP 57400, 95943 Roissy CdG Cedex, France.

\section{Corresponding Author}

*G.B. ; phone : 0033 (0) 140272402 ; e-mail : guillaume.bort@cnam.fr.

\section{Author Contributions}

C.F., M.P., S.C. and G.B. developed the medicinal chemistry strategy. G.B. and H.B. designed the compounds and performed the chemical syntheses and relaxivity characterisations. A.K.

performed the chemical syntheses. S.B. performed the binding study and G.L. carried out the study on BBB crossing. G.B. wrote the manuscript. All authors have given approval to the final version of the manuscript. 


\begin{abstract}
While important efforts were made in the development of positron emission tomography (PET) tracers for the in vivo molecular diagnosis of Alzheimer's disease, very few investigations to develop magnetic resonance imaging (MRI) probes were performed. Here, a new generation of $\mathrm{Gd}(\mathrm{III})$-based contrast agents (CAs) is proposed to detect the amyloid $\beta$-protein (A $\beta$ ) aggregates by MRI, one of the earliest biological hallmarks of the pathology. A building block strategy was used to synthesize a library of 16 CAs to investigate structure-activity relationships (SARs) on physicochemical properties and binding affinity for the $A \beta$ aggregates. Three types of blocks were used to modulate the CA structures: (i) the Gd(III) chelates (Gd(III)-DOTA and Gd(III)PCTA), (ii) the biovectors (2-arylbenzothiazole, 2-arylbenzoxazole and stilbene derivatives) and (iii) the linkers (neutrals, positives and negatives with several lengths). These investigations revealed unexpected SARs and a difficulty of these probes to cross the blood-brain barrier (BBB). General insights for the development of Gd(III)-based CAs to detect the A $\beta$ aggregates are described.
\end{abstract}

\title{
Keywords
}

Alzheimer's disease, amyloid, gadolinium, DOTA, Pyridine Containing TriAza (PCTA), magnetic resonance imaging (MRI). 


\section{Abbreviations}

BAT, bis-amine-bis-thiol; BTA, 2-(4- $N$-methylaminophenyl)benzothiazole; CA, contrast agent; $\mathrm{CMC}$, critic micelle concentration; $\mathrm{CV}$, cone voltage; DIEA, $N, N$-diisopropylethylamine; DOTA, 1,4,7,10-tetraazacyclododecane-1,4,7,10-tetraacetic acid; EDCI HCl, 1-(3dimethylaminopropyl)-3-ethyl-carbodiimide hydrochloride; FDG, fluorodesoxyglucose; HBTU, $O$-Benzotriazole- $N, N, N^{\prime}, N^{\prime}$-tetramethyl-uronium-hexafluoro-phosphate; HEPES, 4-(2hydroxyethyl)-1-piperazineethanesulfonic acid; HOBt, 1-hydroxybenzotriazole; IBOX, 2-(4dimethylaminophenyl)-6-iodobenzoxazole; ICP-AES, inductively coupled plasma-atomic emission spectroscopy; ICP-MS, inductively coupled plasma-mass spectroscopy; IMPY, 6-iodo2-(4'-dimethylamino)-phenyl-imidazo[1,2-a]pyridine; LRMS, low-resolution mass spectroscopy; MAMA, monoamide-monoaminedithiol; MCI, mild cognitive impairment; MION, monocristalline iron oxide nanoparticle; NHS, $N$-hydroxysuccinimide; PCTA, 3,6,9,15-tetraaza bicyclo[9.3.1]-pentadeca-1(15),11,13-triene-3,6,9-triacetic acid; PIB, Pittsburgh Compound-B; $\mathrm{r}_{1}$, longitudinal relaxivity; $\mathrm{r}_{2}$, transversal relaxivities; $\mathrm{SB}$, stilbene; $\mathrm{T}_{1}$, spin-lattice relaxation time; $\mathrm{T}_{2}$, spin-spin relaxation time; th-T, thioflavin-T; UBTA, $N, N^{\prime}$-bis[2-mercapto-2methylpropyl]2-aminobenzylamine; USPIO, utrasmall superparamagnetic iron oxide. 


\section{Introduction}

Alzheimer's disease $(\mathrm{AD})$ is a progressive neurodegenerative disorder responsible for $60 \%$ to $70 \%$ of dementia cases. About $6 \%$ of the population aged 65 and older suffer from dementia, which represented 36 million people worldwide in 2010 with a total societal cost estimated to be US\$ 604 billion. The number of AD patients is believed to double every 20 years to potentially reach 115 million by 2050.[1] AD has both societal and economical impacts on our society and is expected to become one of the major health care problems for industrialized countries in the future.[2] As a matter of fact, the research for a treatment and an early diagnosis of AD, with in vivo imaging of amyloid plaques as the most promising technique,[3] appears today as a priority.[4]

In the last 20 years, the research on $\mathrm{AD}$ focused on the development of different therapeutic approaches and diagnostic techniques to detect the pathology at an early stage.[5] However, to date the definitive diagnosis of AD can be performed post-mortem only.[6] An early diagnosis of $\mathrm{AD}$ would allow not only an intervention with future disease-modifying therapies right from the start of the disease, but also a relevant follow-up of drugs tested.[7] The neuropathological hallmarks of $\mathrm{AD}$ are intracellular neurofibrillary tangles, caused by the hyperphosphorylation of tau proteins, and extracellular neuritic plaques, caused by the aggregation of amyloid $\beta$-protein (A $\beta$ ) fibrils, accompanied with neurotransmitter deficits. The "amyloid hypothesis",[8] today accepted by a large part of the scientific community, suggests that $A \beta$ plaques appear in the brain 10 to 20 years before the first clinical symptoms of $\mathrm{AD}$. The $\mathrm{A} \beta$ aggregates are believed to be one of the most relevant hallmarks along the AD evolution process.[9-10] In vivo methods for 
amyloid imaging,[11] together with cerebrospinal fluid biomarkers, as well as functional monitoring of the brain (glucose metabolism with $\left[{ }^{18} \mathrm{~F}\right]$ fluorodesoxyglucose $\left(\left[{ }^{18} \mathrm{~F}\right] \mathrm{FDG}\right)$ or neurotransmitter activity),[10,12] are expected to have a high potential to specifically diagnose $\mathrm{AD}$ patients at a very early stage. During the last 10 years, various molecular imaging radiolabeled tracers have been reported for the detection of amyloid deposits by single-photon emission computed tomography (SPECT) and positron emission tomography (PET) and some are currently assessed on clinical trials.[10,13-15] Florbetapir- ${ }^{18} \mathrm{~F}$ has been the first amyloid specific ${ }^{18}$ F PET tracer approved by the Food and Drug Administration (FDA) in 2012 for adults being evaluated for $\mathrm{AD}$ or other cognitive disorders.[16] The detection of amyloid deposits in human with the Pittsburgh Compound-B $\left(\left[{ }^{11} \mathrm{C}\right] \mathrm{PIB}\right)$ and Florbetapir- ${ }^{18} \mathrm{~F}$ by PET imaging showed to be able to differentiate a population at risk of developing $\mathrm{AD}$ from mild cognitive impairment (MCI) patients.[17-19] Interestingly, around 20-40\% of asymptomatic controls showed a $\left[{ }^{11} \mathrm{C}\right] \mathrm{PIB}$ retention, $[20-24]$ which suggests that this compound might be an efficient tracer for $\mathrm{AD}$ preclinical diagnosis since the major growth of amyloid burden seems to occur at this stage of the disease.[25-27]

The development of probes for the detection of the AD hallmarks by nuclear magnetic resonance imaging (MRI) has been much less successful, mainly due to the lower sensitivity of this technique compared to PET and SPECT. To date, magnetic probes have been studied only at a pre-clinical stage. However, the advantages provided by MRI over radionuclide-based imaging techniques encouraged us to investigate in this direction. Compared to SPECT or PET, MRI technique does not require the injection of radioactive probes, has better resolution $(200 \mu \mathrm{m}$ to $50 \mu \mathrm{m}$ for clinical and research magnets respectively) and provides anatomic information which 
could be relevant for quantifying amyloid deposits and characterising precisely the deposition areas.[28-29] The high resolution achievable by MRI makes the detection of amyloid lesions possible both in humans and animals, which is also critical for the evaluation of new treatments against $\mathrm{AD}$ at early stages. Moreover, the lower cost, wider availability and the absence of irradiation of the MRI exams afford important advantages.

Contrary to radionuclide-based imaging techniques such as PET and SPECT, MRI does not allow the direct detection of the CA. Indeed the signal detected by MRI is the relaxation rate enhancement of the spins of the water protons in close proximity to the paramagnetic Gd(III) lanthanide. This complex interaction usually prevents the correlation of the local Gd(III) concentration with the MRI signal variation detected in biological media because of the influence of the surrounding of the water protons on the effect of the Gd(III) lanthanide. Nevertheless, specialists agree that the detection of $\mathrm{Gd}^{3+}$ ions at concentration of $1-10 \mu \mathrm{M}$ in the brain could be achieved by using Gd(III)-based MRI CAs with relaxivity equivalent to commercial MRI CAs (i.e. $3 \mathrm{mM}^{-1} \cdot \mathrm{s}^{-1} \cdot \mathrm{Gd}^{-1}$ ) and clinical MRI equipment. However, both the density of the targeted site and the relaxivity of the CA bound to the targeted site influence the local concentration of $\mathrm{Gd}^{3+}$ ions required for MRI detection. For instance, S. Aime et al. estimate that $4 \pm 1 \times 10^{7} \mathrm{Gd}^{3+}$ ions per cell are required to reach a concentration sufficient to be detected in vivo, leading to a local $\mathrm{Gd}^{3+}$ ion concentration of $2 \mu \mathrm{M}$.[30] C. Corot et al. reported a folate receptor targeting $\mathrm{Gd}(\mathrm{III})$-based $\mathrm{CA}$ which requires a local $\mathrm{Gd}^{3+}$ ion concentration of $0.92 \mu \mathrm{M}$ to be detected in vitro thanks to its high longitudinal relaxivity $\left(\mathrm{r}_{1}=25 \mathrm{mM}^{-1} \cdot \mathrm{s}^{-1} \cdot \mathrm{Gd}^{-1}, 2.35 \mathrm{~T}, 37\right.$ $\left.{ }^{\circ} \mathrm{C}\right) .[31]$ The density of $\mathrm{A} \beta$ peptides in $\mathrm{AD}$ frontal cortex brain was determined at 1-3 $\mu \mathrm{M}[32]$ and the binding stoichiometry of $\mathrm{CAs}$ to $\mathrm{A} \beta$ in $\mathrm{AD}$ brain is close to 1:1 under saturating 
conditions.[33] Considering that a relaxivity enhancement of the $\mathrm{CAs}\left(\sim \mathrm{x} 2\right.$ at $\left.60 \mathrm{MHz}, 37^{\circ} \mathrm{C}\right)$ is expected after binding to the amyloid aggregates, thanks to an increase of the rotational correlation time,[34] CAs with relaxivities around $10 \pm 5 \mathrm{mM}^{-1} \cdot \mathrm{s}^{-1}$ have a great potential to dectect amyloid aggregates in vivo if the targeted sites can be reached.

Several Gd-based CA have been reported for the detection of amyloid aggregates in mice by MRI. The Gd ${ }^{\mathrm{III}}$ diethylenetriaminepentaacetic acid (Gd(III)-DTPA) complex was first attached to

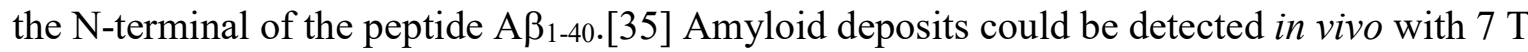
$\mu \mathrm{MRI}$ and $\mathrm{T}_{2} *$ weighted images after transient opening of the blood-brain barrier (BBB) with mannitol. Several ways to enhance BBB permeability of the probes were investigated further. The introduction of putrescine moieties on the peptide $A \beta_{1-40[36]}$ and on the truncated derivative $A \beta_{1-30[37]}$ by modification on glutaric acid and aspartic acid residues were investigated by intravenous injections in APP/PS1 transgenic mice and ex vivo detection of the probes. The peptide $A \beta_{1-30}$ elongated with 6 lysine residues was attached to the Gd(III)-DTPA chelate and the CA was dissolved in a mannitol containing buffer before intracarotid injection in a $\mathrm{Tg} 2576$ mouse and in vivo detection with $7 \mathrm{~T} \mu \mathrm{MRI}$ and $\mathrm{T}_{2} *$ weighted images.[38] Even if these structure modifications improved BBB permeability without affecting the binding on amyloid deposits, these probes do not cross the BBB enough to be detected in vivo by MRI when adjuvants such as mannitol is not used. Recently, a PIB derivative labeled with Gd(III), ${ }^{111} \mathrm{In}(\mathrm{III})$ and $\mathrm{Eu}(\mathrm{III})$ was reported.[39] In spite of a low binding affinity for the $A \beta_{1-40}$ aggregates $\left(\mathrm{K}_{\mathrm{d}}=\right.$ $180 \mu \mathrm{M})$, the $\mathrm{Eu}(\mathrm{III})$ derivative CA showed to successfully label the amyloid deposits in postmortem human brain tissues of $\mathrm{AD}$ patients. However, the $\mathrm{BBB}$ permeability of the $\mathrm{CA}$ was 
expected to be insufficient for in vivo MRI detection. The solubility and the parameters determining the relaxivity of the Gd(III) derivatives was successfully tuned by modifying the linker between the Gd(III) chelate and the PIB derivative.[34] Iron oxide particles such as monocristalline iron oxide nanoparticles[35] (MIONs) and utrasmall superparamagnetic iron oxide (USPIO) nanoparticles,[40] labeled with $A \beta_{1-40}$ and $A \beta_{1-42}$ respectively, have been investigated with similar approaches and were able to bind the amyloid aggregates in vivo after injection in APP/PS1 transgenic AD mice with 15\% mannitol in phosphate buffer saline (PBS). Similarly, these probes validated the possibility to detect amyloid in vivo by MRI but their use was limited by a poor BBB permeability. Introduction of PEG on the surface of $A \beta_{1-42}$ modified USPIO significantly improved the BBB permeability of the CA.[41] After intravanous injection of this CA without adjuvant, $\mathrm{A} \beta$ aggregates were clearly detected ex vivo (overnight scanning, 7 $\mathrm{T} \mu \mathrm{MRI}, \mathrm{T}_{2} *$ weighted images). However, in vivo detection was more uncertain due to the low sensitivity and the high background resulting from blood vessels. To date, there is no efficient MRI CA available to detect the amyloid deposits at the early stage of the disease in a living patient. The few studies describing in vivo detection of amyloid deposits by MRI all required a co-injection of the $\mathrm{CA}$ with mannitol to transiently open the BBB, which prevents applications in clinical trials. For these reasons, new types of CA need to be developed for clinical use.

Among the large numbers of PET tracers developed in the last decade for the detection of amyloid deposits, some showed to be particularly attractive for further development (Fig. 1). The thioflavin- $\mathrm{T}$ (th-T) derivative $\left[{ }^{11} \mathrm{C}\right] \mathrm{PIB}(\mathbf{1})$, a carbon-11 radionuclide marker of $\mathrm{A} \beta$ plaques, $[33,42]$ is currently the most widely used among the few PET tracers in clinical 
trials.[43-49] This gold-standard amyloid PET tracer is in the phase III clinical trials and is often used as a reference to compare the efficiency of new potent markers of $A \beta$ plaques.[50] The $N, N$ '-dimethylated analog of the $\left[{ }^{11} \mathrm{C}\right] \mathrm{PIB}$ revealed similar binding properties with an inhibition constant $\left(\mathrm{K}_{\mathrm{i}}\right)$ of $4.4 \mathrm{nM}\left(v s 4.3 \mathrm{nM}\right.$ for $\left.\left[{ }^{11} \mathrm{C}\right] \mathrm{PIB}\right)$ on $\mathrm{A} \beta_{1-40}$ aggregates $(2-(4-N-$ methylaminophenyl)benzothiazole $\left(\left[{ }^{3} \mathrm{H}\right] \mathrm{BTA}\right)$ as competitor $) .[51]$ The 2-(4dimethylaminophenyl)-6-iodobenzoxazole ([ $\left.\left.{ }^{123} \mathrm{I}\right] \mathrm{IBOX}, 2\right)$, a benzoxazole analog of the $\left[{ }^{11} \mathrm{C}\right] \mathrm{PIB}$ labeled with iodine 123, was reported to efficiently bind amyloid aggregates in post-mortem brain sections of confirmed AD patients.[52] The affinities of several stilbene derivatives for amyloid aggregates in $\mathrm{AD}$ patient brain homogenates were reported[53-54] and the radiopharmaceutical 4-( $N$-methylamino)-4'-hydroxy-trans-stilbene $\left(K_{\mathrm{d}} 2.4 \mathrm{nM},\left[{ }^{3} \mathrm{H}\right] \mathrm{SB}-13,3\right)$ was selected for further investigations in human.[55]

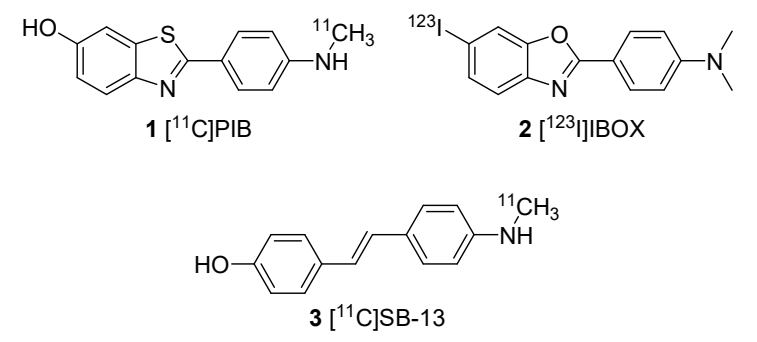

Fig. 1. Chemical structures of amyloid specific ligands $\left[{ }^{11} \mathrm{C}\right] \mathrm{PIB}(\mathbf{1}),\left[{ }^{123} \mathrm{I}\right] \mathrm{IBOX}(\mathbf{2})$ and $\left[{ }^{11} \mathrm{C}\right] \mathrm{SB}-13(3)$. 
The structure of these three radiopharmaceuticals inspired us for the design of the biovectors aiming to target the CAs on the amyloid deposits. These low MW chromophores contrast with the long peptide chains previously required to target the MRI CAs. The new generation of CAs investigated was expected to have a different biodistribution profile than those previously developped and cross the BBB. The carbon carrying the hydroxyl function or the iodide atom was selected as the most suitable anchor to graft the imaging moiety according to the previously reported structure-activity relationship (SAR) studies on th-T[56] and stilbene[57] derivatives. Structurally similar probes carrying the metal ${ }^{99 \mathrm{~m}} \mathrm{Tc}$ have been described in the literature for SPECT imaging of amyloid aggregates (Fig. 2). A modified N,N'-bis[2-mercapto-2methylpropyl]2-aminobenzylamine (UBTA) ${ }^{99} \mathrm{~m}$ Tc complex grafted to a diphenyl derivative biovector (4) showed to bind the amyloid on brain slices from transgenic mouse APP/PS1 and to cross the BBB in the mouse (1.18\% ID/g at $2 \mathrm{~min})$.[58] The ${ }^{99 \mathrm{~m}} \mathrm{Tc}$ complex monoamidemonoaminedithiol (MAMA) conjugated with a PIB analog (5) showed a high affinity on AD patient homogenates and an ability to cross the BBB $(1.34 \% \mathrm{ID} / \mathrm{g}$ at $2 \mathrm{~min})$ in the mouse despite a strong plasma protein adsorption.[59] Finally, a chalcone derivative modified with the bisamine-bis-thiol (BAT) ${ }^{99 \mathrm{~m}} \mathrm{Tc}$ complex (6) showed high amyloid affinity and brain penetration (1.48\% ID/g at $2 \mathrm{~min}$ ).[60] These encouraging results on BBB permeability of these SPECT probes inspired us to design MRI probes with similar chemical structures. 

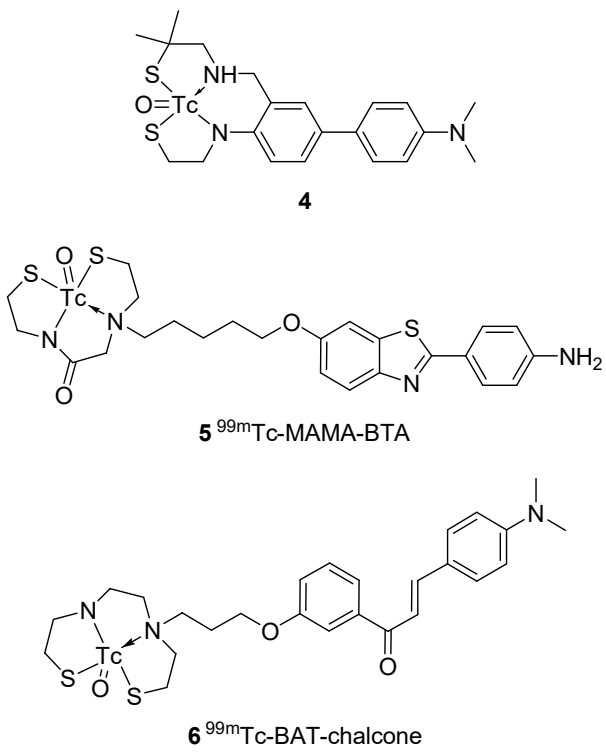

Fig. 2. Amyloid specific probes for SPECT imaging of amyloid aggregates.

Herein we describe a new generation of Gd-based CAs designed to detect the amyloid deposits by MRI. These probes are constituted of three parts: (i) a Gd(III)-complex as imaging moiety, (ii) an amyloid binding ligand as biovector, and (iii) a linker to bind these two entities. The Gd ${ }^{\mathrm{III}}$ 3,6,9,15-tetraaza bicyclo[9.3.1]-pentadeca-1(15),11,13-triene-3,6,9-triacetic acid (Gd(III)-PCTA) and the Gd ${ }^{\mathrm{III}}-1,4,7,10$-tetraazacyclododecane-1,4,7,10-tetraacetic acid (Gd(III)-DOTA) chelates were used as imaging moieties.[61] The cyclic structure of the PCTA and the DOTA ligands provides high kinetic and/or thermodynamic stability to the $\mathrm{Gd}(\mathrm{III})$ chelates necessary for in vivo applications.[62-63] Three biovectors, derivatives of PIB, IBOX and stilbene, were used to target the CAs on the amyloid aggregates. Different types of linkers with neutral, positive(s) or negative(s) charge(s) have been incorporated to modulate the physicochemical properties of the CAs. The affinity for the amyloid aggregates and BBB permeability of 16 CAs were then determined to establish SARs in this new class of CAs. Key structural considerations for the 
future development of Gd(III)-based CAs for the detection of amyloid aggregates are highlighted by this study.

\section{Chemistry.}

The Gd(III)-PCTA complex modified with a carboxylic function anchored on the pyridine core (Gd-PCTA12) was synthesized as previously described through a pathway involving a key macrocyclisation step controlled by the template effect of $\mathrm{Na}^{+}$ions (Scheme 1A).[64] The Gd ${ }^{\text {III }}$ 1,4,7,10-tetraazacyclododecane-1-glutaric acid-4,7,10-triacetic acid (Gd-DOTAGA),[65] a derivative of the Gd(III)-DOTA modified with a glutaric acid linker, was synthesized by trialkylation of the cyclene in dimethylacetamide in the presence of sodium acetate (Scheme 1B). The remaining nitrogen atom was then alkylated to introduce the glutarate arm. The complex Gd-DOTAGA was obtained after deprotection and complexation of the ligand. Both Gd(III) chelates contain a free carboxylic acid group which was further used as an anchor for coupling a biovector or a linker. 
A.
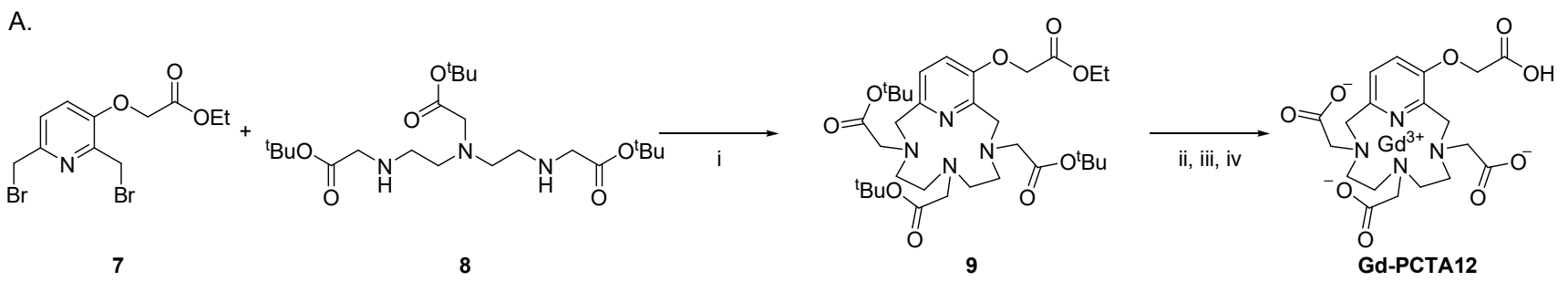

B.

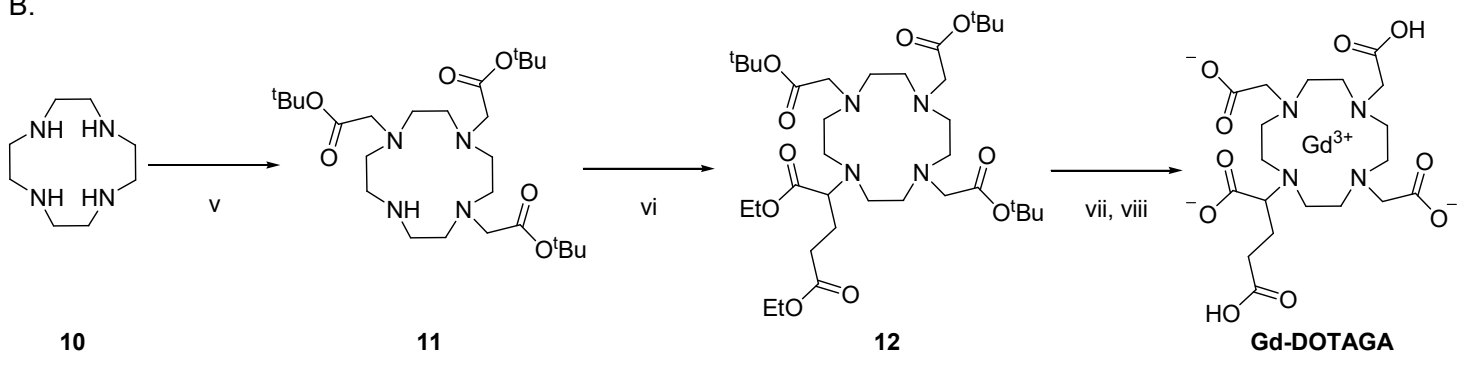

Scheme 1. Synthesis of the imaging moieties Gd(III)-PCTA (A) and Gd(III)-DOTA (B). (i) $\mathrm{Na}_{2} \mathrm{CO}_{3}$ (4 equiv), dimethylformamide (DMF), $80{ }^{\circ} \mathrm{C}, 3 \mathrm{~h}(87 \%$ ); (ii) $1 \mathrm{~N} \mathrm{NaOH}$, ethanol, room temperature (rt), $5 \mathrm{~h}$; (iii) $\mathrm{Et}_{2} \mathrm{O}-2 \mathrm{~N} \mathrm{HCl}$, dichloromethane (DCM), rt, $17 \mathrm{~h}$; (iv) $\mathrm{Gd}_{2} \mathrm{O}_{3}(0.5$

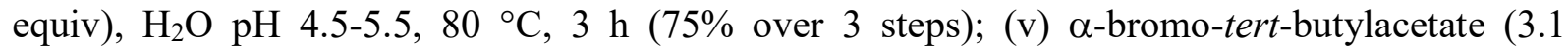
equiv), AcONa (3.1 equiv), dimethylacetamide (DMA), rt, 3 weeks (60\%); (vi) $\alpha$-bromoethylglutarate (2.5 equiv), $\mathrm{K}_{2} \mathrm{CO}_{3}\left(2.5\right.$ equiv), acetonitrile, $80{ }^{\circ} \mathrm{C}, 28 \mathrm{~h}(67 \%)$; (vii) $12 \mathrm{~N} \mathrm{HCl}$, reflux, $3 \mathrm{~d}$ (51\%); (viii) $\mathrm{Gd}_{2} \mathrm{O}_{3}$ (0.5 equiv), $\mathrm{H}_{2} \mathrm{O} \mathrm{pH} 4.5-5.5,80{ }^{\circ} \mathrm{C}, 6 \mathrm{~h}(93 \%)$.

The common pathways described in the literature for the synthesis of PIB derivatives report multi-step syntheses with quite low overall yields ranging from 20 to $40 \%$ involving the Jacobson's oxidative cyclization of substituted thiobenzanilides.[51,66] We recently developed an efficient one-step synthesis of 2-arylbenzothiazole derivatives via a Suzuki-Miyaura crosscoupling under thermal and microwave activation.[67] The hydroxylated PIB derivative $\mathbf{1 6}$ was synthesized following this method from two commercially available compounds in $80 \%$ yield (Scheme 2A). Interestingly the synthon $\mathbf{1 5}$ can also be easily prepared in two steps from cheap reagents. A Sandmeyer-type reaction on the 2-amino-6-methoxybenzothiazole (13) in the presence of $\mathrm{CuBr}_{2}$ and tert-butylnitrite in anhydrous conditions led to the brominated 
intermediate 14 in $92 \%$ yield. The water-free conditions limited the formation of the 2-hydroxy6-methoxybenzothiazole by-product. A careful sequential introduction of the reagents and a controlled heating time prevented the formation of the 2,7-dibromo-6-methoxybenzothiazole and 2-chloro-6-methoxybenzothiazole by-products. A deprotection of the phenolic function by $\mathrm{BBr}_{3}$ led to the 2-bromo-6-hydroxy-benzothiazole (15).

A.

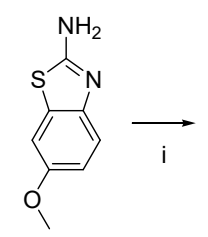

13<smiles>CCCCCC</smiles>

14

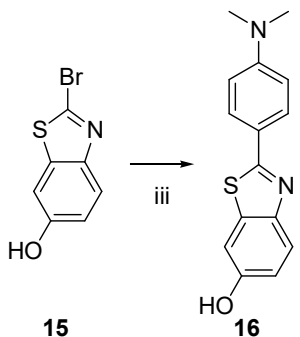

B.<smiles>COc1ccc(NC(=O)c2ccc(N(C)C)cc2)c(F)c1</smiles><smiles>CN(C)c1ccc(-c2nc3ccc(O)cc3o2)cc1</smiles>

17

18

19

c.

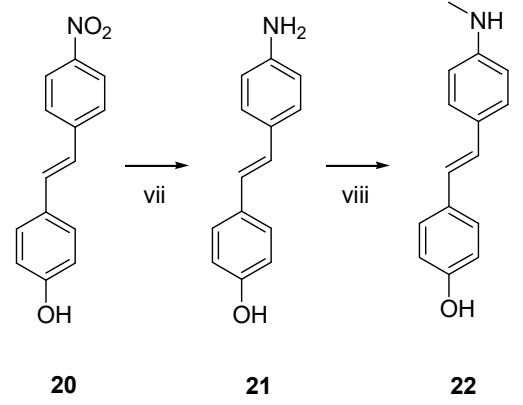

Scheme 2. Synthesis of the biovectors 2-(4- $N, N$-dimethylaminophenyl)-6-hydroxybenzothiazole (16, A), 2-(4-N,N-dimethylaminophenyl)-6-hydroxybenzoxazole $(19, \quad$ B) and 4- $(N-$ methylamino)-4'-hydroxy-trans-stilbene (22, C). (i) $\mathrm{CuBr}_{2}$ (1.5 equiv), 'BuONO (1.5 equiv), acetonitrile, $\mathrm{rt}$ for $2.5 \mathrm{~d}, 65^{\circ} \mathrm{C}$ for $1.5 \mathrm{~h}$ (92\%); (ii) $\mathrm{BBr}_{3}$ (1 M in DCM, 4.7 equiv), DCM, $0{ }^{\circ} \mathrm{C}$ to rt, 20 h (94\%); (iii) $\mathrm{Pd}(\mathrm{dppf}) \mathrm{Cl}_{2}$.DCM (5 mol\%), $\mathrm{K}_{2} \mathrm{CO}_{3}$ (6.0 equiv), DMF, $80{ }^{\circ} \mathrm{C}, 1.5 \mathrm{~h}(80 \%)$; (iv) acyl chloride (1.1 equiv), pyridine, $0{ }^{\circ} \mathrm{C}$ to $\mathrm{rt}, 15 \mathrm{~h}$; (v) $\mathrm{K}_{2} \mathrm{CO}_{3}$ (1.1 equiv), $\mu \mathrm{W}$ (300 W, 230 ${ }^{\circ} \mathrm{C}$, 7-8 bars), $1 \mathrm{~h}$; (vi) $\mathrm{BBr}_{3}$ (4.7 equiv), DCM, $0{ }^{\circ} \mathrm{C}$ to rt, $15 \mathrm{~h}$ (20\% over 3 steps); (vii) $\mathrm{SnCl}_{2}$ (6.1 equiv), $\mathrm{HCl}$ (5.2 equiv), EtOH, reflux to rt, $23 \mathrm{~h}$ (96\%); (viii) 1) paraformaldehyde (8.0 equiv), $\mathrm{MeONa}$ (7.0 equiv), reflux, $3 \mathrm{~h} ; 2$ ) $\mathrm{NaBH}_{4}$ (8.0 equiv), $0{ }^{\circ} \mathrm{C}$ to reflux, $1 \mathrm{~h}(79 \%)$. 
The 2-(4-N,N-dimethylaminophenyl)-6-hydroxybenzoxazole (19) was obtained in $20 \%$ yield over three steps (Scheme 2B). The condensation of the 2-fluoro-4-methoxyaniline (17) on the 4dimethylaminobenzoyl chloride was followed by a cyclisation under microwave irradiation in the presence of $\mathrm{K}_{2} \mathrm{CO}_{3}$ to obtain the benzoxazole core. A final demethylation using $\mathrm{BBr}_{3}$ led to the formation of the 2-arylbenzoxazole derivative 19. The 4-( $N$-methylamino)-4'-hydroxy-transstilbene (22) was synthesized in 69\% yield over 2 steps using conditions adapted from the literature (Scheme 2C).[68] The 4-nitro-4'-hydroxystilbene (20) was reduced with $\mathrm{SnCl}_{2}$ and $\mathrm{HCl}$ in ethanol. The product was isolated by simple filtration before carrying out the mono- $\mathrm{N}$ alkylation of the aniline with paraformaldehyde and sodium methoxide. The subsequent addition of $\mathrm{NaBH}_{4}$ led to the monoalkylated product 22 .

Introduction of an ethylamine linker on the biovectors $\mathbf{1 6}$ and $\mathbf{1 9}$ was first attempted through a Williamson $O$-alkylation with chloroacetonitrile and $\mathrm{K}_{2} \mathrm{CO}_{3}$, followed by hydrogenation of the nitrile function in the presence of $\mathrm{Pd} / \mathrm{C}$ (Scheme 3). The alkylation run smoothly but the hydrogenation step was less efficient ( $41 \%$ and $48 \%$ yield respectively). This was mainly caused by the generation of the hydroxylated by-products $\mathbf{1 6}$ and $\mathbf{1 9}$ resulting from the cleavage of the cyanomethyl moiety through by the probable formation of an iminium intermediate isomerised into the allyl form by interaction with Pd, as previously reported with similar reagents. [69] The reduction of the nitrile function with $\mathrm{BH}_{3}$-THF gave the desired amine product in variable yield ( $25 \%$ to $68 \%$ ) caused by the difficult dissociation of the final boron chelates.[70] Another approach to introduce the linker through $O$-alkylation of $\mathbf{1 6}$ with the tert-butoxycarbonyl-(boc)protected chloroethylamine followed by a treatment in trifluoroacetic acid (TFA) led to compound 23 in reproducible yield (36\% over 2 steps) (Scheme 3$)$. Introduction of the 
ethylamine linker on the biovector $\mathbf{2 2}$ was achieved using a similar pathway. Finally, peptide coupling reactions of the ethylamine terminated biovectors with the Gd-PCTA12 or Gd-

DOTAGA chelates led to a first library of 5 relatively small CAs (MW $<1000$ Da) containing a neutral linker (Scheme 3 and Supporting Information Table S2).
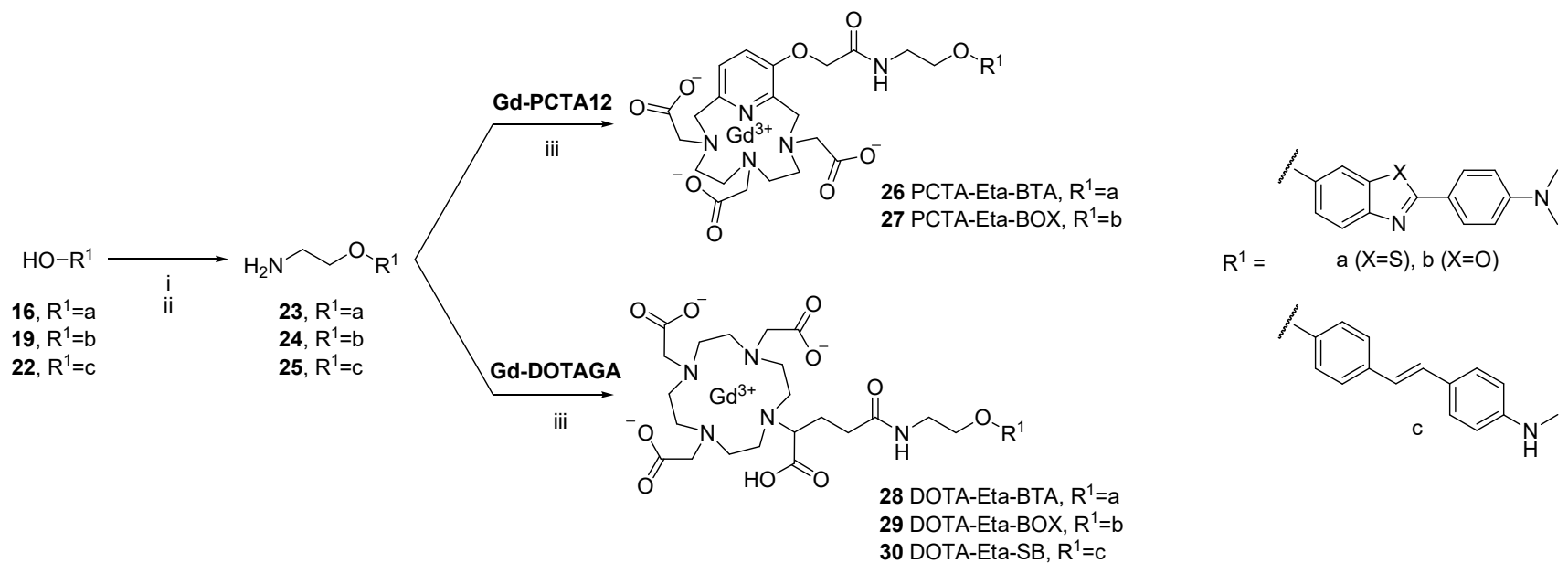

Scheme 3. Synthesis of the CAs containing a neutral linker. For the synthesis of 23 and 25: (i) $\mathrm{N}$ (tert-butyloxycarbonic acid)-chloroethylamine (1.2 equiv), $\mathrm{K}_{2} \mathrm{CO}_{3}$ (3.3 equiv), $\mathrm{DMF}, 100{ }^{\circ} \mathrm{C}, 19$ h (42\%); (ii) DCM/TFA 4:1, rt, $1 \mathrm{~h}$ (85\%); For the synthesis of 24: (i) chloroacetonitrile (4.3 equiv), $\mathrm{K}_{2} \mathrm{CO}_{3}$ (1.5 equiv), acetone, $60{ }^{\circ} \mathrm{C}, 20 \mathrm{~h}$ (79\%); (ii) $\mathrm{BH}_{3}$ (11 equiv), tetrahydrofurane (THF), $70{ }^{\circ} \mathrm{C}, 15 \mathrm{~h} \mathrm{(48 \% );} \mathrm{(iii)} \mathrm{Gd-PCTA12} \mathrm{or} \mathrm{Gd-DOTAGA} \mathrm{(1.0-3.1} \mathrm{equiv),} \mathrm{1-(3-}$ dimethylaminopropyl)-3-ethyl-carbodiimide hydrochloride (EDCI $\mathrm{HCl}$ ) (1.3-7.3 equiv), 1hydroxybenzotriazole (HOBt) (0.3-0.5 equiv), $\mathrm{H}_{2} \mathrm{O} / \mathrm{DMF}$ or $\mathrm{H}_{2} \mathrm{O}$ /dimethyl sulfoxide (DMSO) pH 6, rt, 1-63 h (8-65\%). Eta: ethylamine linker.

The building block strategy adopted to synthesize the CAs enables easy access to a large chemical diversity for these probes. Amino acid derivatives are particularly convenient building blocks to be inserted between the Gd(III) chelates and the ethylamine terminated biovectors because of their terminal carboxylic acid and amine functions. Lysine and arginine residues were 
selected because of their positively charged lateral chains under physiological conditions (vide infra). The coupling of the different blocks was performed through a $N$-elongation from the ethylamine terminated biovectors to the Gd(III) chelates (Scheme 4 and Supporting Information Tables S1, S2). A final treatment in TFA was performed to deprotect the boc or the 2,2,4,6,7pentamethyldihydrobenzofuran-5-sulfonyl ( $\mathrm{Pbf}$ ) protecting groups of the lysine and arginine lateral chains respectively. The short deprotection time, followed by the rapid neutralisation of the Gd(III) chelate in cold water, prevented the decomplexation of the $\mathrm{Gd}^{3+}$ ions.

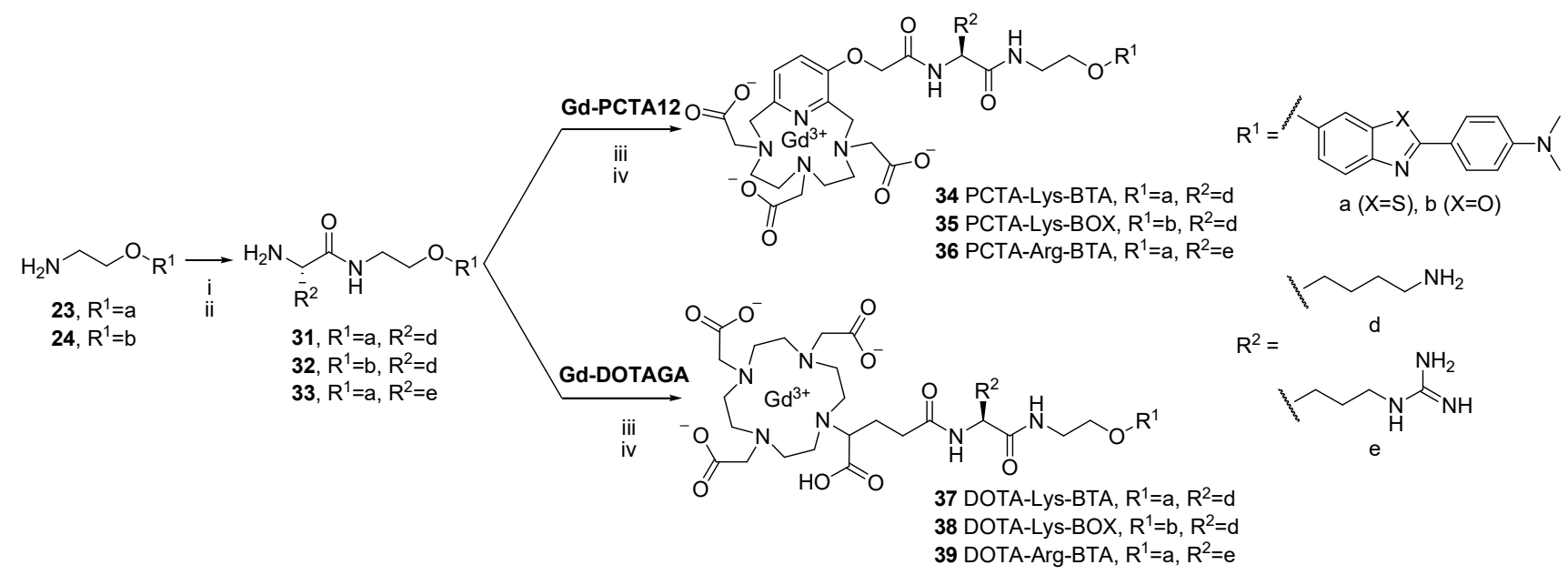

Scheme 4. Synthesis of the CAs containing a positively charged linker. (i) Fmoc(Lys-boc)OH or Fmoc(Arg-Pbf)OH (1.2-1.4 equiv), EDCI HCl (1.1-1.6 equiv), HOBt (0.2-0.4 equiv), DMF or DCM, rt, 20-72 h (79-96\%); (ii) Piperidine (0.2 equiv), DMF, rt, 20 h (89\%-quant); (iii) GdPCTA12 or Gd-DOTAGA (1.0-2.6 equiv), EDCI HCl (1.3-9.2 equiv), HOBt (0.5 equiv), $\mathrm{H}_{2} \mathrm{O} / \mathrm{DMF}$ or $\mathrm{H}_{2} \mathrm{O} / \mathrm{DMSO} \mathrm{pH}$ 6, rt, 20-62 h; (iv) TFA, rt, 1.5-2 h (8-65\% over 2 steps).

The impact of multicharged linkers in the CA framework was assessed by the introduction of three charged residues on the linker. A dipeptide was conjugated on the previously modified 
biovectors 31 and 33. The $N$-9-fluorenylmethyloxycarbonyl (Fmoc) protected dilysine (41) and diarginine (43) synthons were synthesized in one coupling step by activating the carboxylic acid function of the Fmoc protected aminoacid with $N$-hydroxysuccinimide (NHS) and $N, N^{\prime}-$ dicyclohexylcarbodiimide (DCC) followed by the introduction of the non-protected aminoacid into the reaction mixture (Scheme 5).

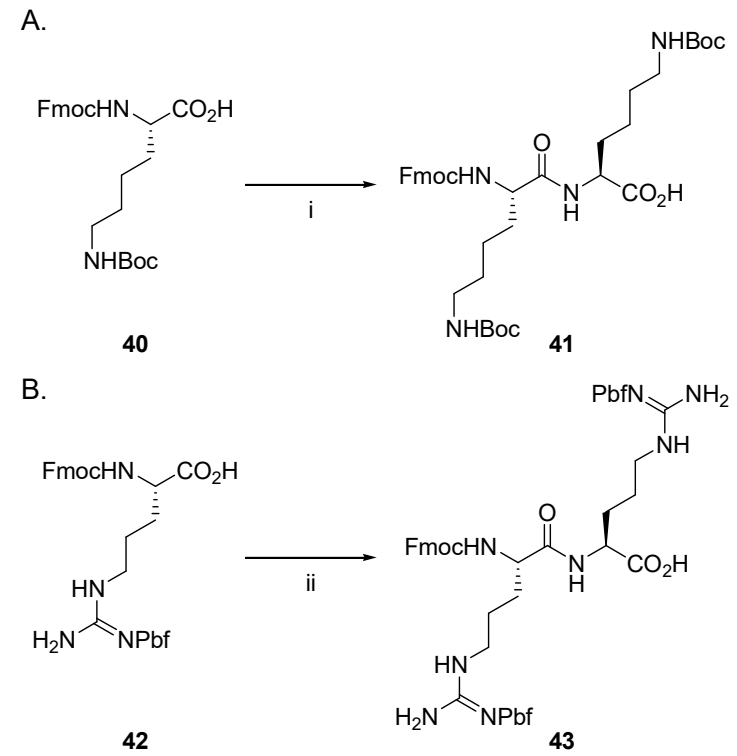

Scheme 5. Synthesis of the Fmoc protected dilysine (41, A) and diarginine (43, B) synthons. (i) 1) DCC (1.1 equiv), NHS (1.3 equiv), acetonitrile, rt, $23 \mathrm{~h} ; 2) \mathrm{H}_{2} \mathrm{~N}$ (Lys-boc)OH (1.0 equiv), $\mathrm{NaHCO}_{3} 6.8 \%$ /acetonitrile $1: 3,0{ }^{\circ} \mathrm{C}$ to rt, $19 \mathrm{~h}(69 \%)$; (ii) 1) DCC (1.0 equiv), NHS (1.0 equiv), DMF, rt, $17 \mathrm{~h}$; 2) $\mathrm{H}_{2} \mathrm{~N}$ (Lys-boc)OH (1.0 equiv), $\mathrm{NaHCO}_{3} 6.8 \% / \mathrm{DMF} 1: 3,0{ }^{\circ} \mathrm{C}$ to $\mathrm{rt}, 1 \mathrm{~h}(77 \%)$.

Conjugations of the dipeptides on the modified biovectors and on the Gd(III) chelates were performed using classical peptide coupling conditions to obtain CAs carrying a trimeric positively charged linker (Scheme 6 and Supporting Information Tables S1, S2). 


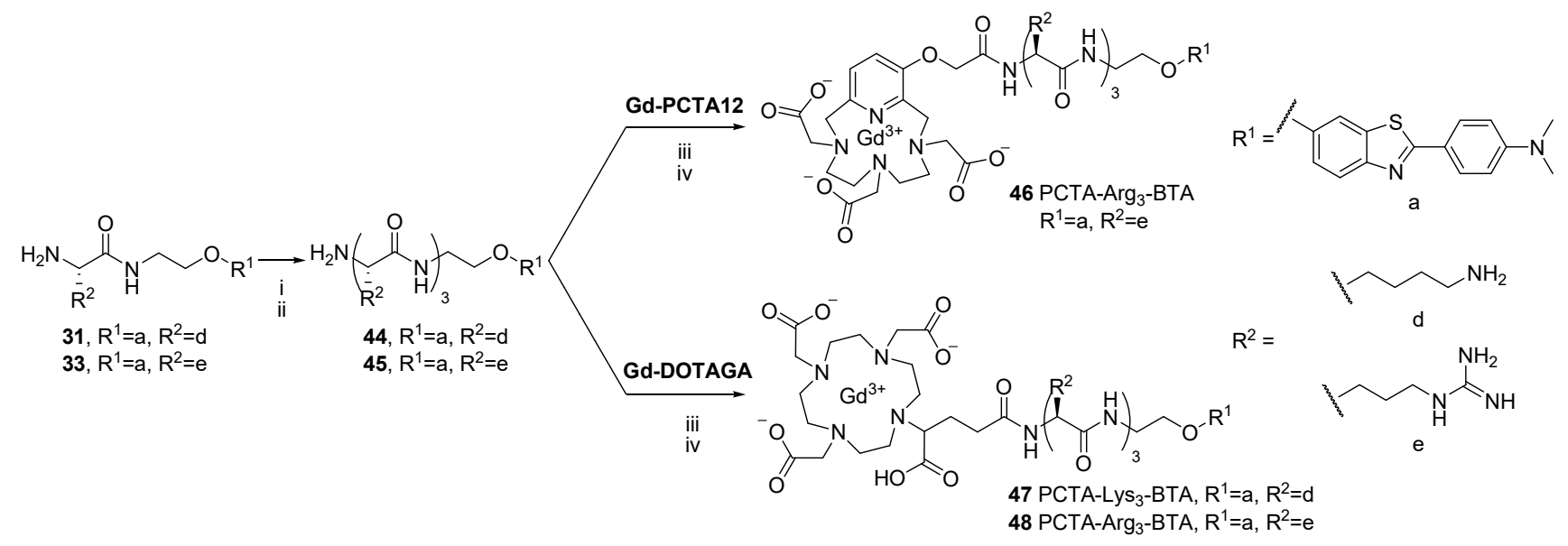

Scheme 6. Synthesis of the CAs containing a trimeric positively charged linker. (i) $\mathbf{4 1}$ or $\mathbf{4 3}$ (1.0 equiv), $\mathrm{EDCI} \mathrm{HCl}$ (1.1-6.0 equiv), $\mathrm{HOBt}$ (0.2-0.5 equiv), DMF or DCM, rt, 4-20 h (37-79\%); (ii) Piperidine (0.2 equiv), DMF, rt, 20 h (77\%-quant); (iii) Gd-PCTA12 or Gd-DOTAGA (1.5-1.7 equiv), $\mathrm{EDCI} \mathrm{HCl}$ (1.3-16.7 equiv), $\mathrm{HOBt}$ (0.5 equiv), $\mathrm{H}_{2} \mathrm{O} / \mathrm{DMF}$ or $\mathrm{H}_{2} \mathrm{O} / \mathrm{DMSO} \mathrm{pH} 6$, rt, 20-45 h; (iv) TFA, rt, 1.5-2 h (8-37\% over 2 steps).

Similarly, anionic linkers were introduced in the CA framework. The $\alpha$-sulfo- $\beta$-alanine moiety was selected as negatively charged building block as it enables the same synthetic scheme through peptide coupling chemistry. The two Fmoc protected $\alpha$-sulfo- $\beta$-alanine[71] and bis $(\alpha-$ sulfo- $\beta$-alaninyl)- $\alpha$-sulfo- $\beta$-alanine[72] synthons were synthesized as previously reported and coupled on the ethylamine terminated biovector $\mathbf{3 1}$ before introducing the Gd(III) chelate GdDOTAGA (Scheme 7). 


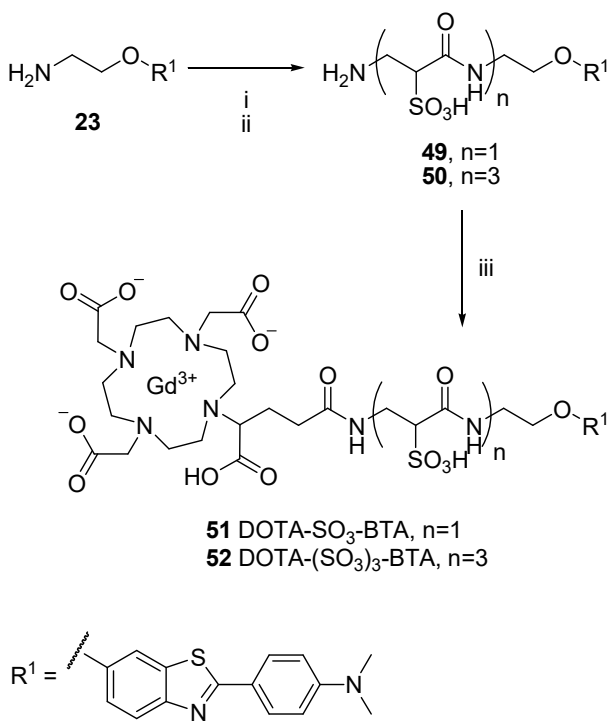

Scheme 7. Synthesis of the CAs containing a mono- or a tri-anionic linker. For the synthesis of 49: (i) Fmoc- $\alpha$-sulfo- $\beta$-alanine (1.3 equiv), EDCI $\mathrm{HCl}$ (2.0 equiv), $\mathrm{HOBt}(0.5$ equiv), DMF, rt, $24 \mathrm{~h}$ (45\%); (ii) Piperidine (1 equiv), DMF, rt, 15 h (96\%); For the synthesis of 50: (i) Fmocbis( $\alpha$-sulfo- $\beta$-alaninyl)- $\alpha$-sulfo- $\beta$-alanine (1.0 equiv), $O$-Benzotriazole- $N, N, N^{\prime}, N^{\prime}$-tetramethyluronium-hexafluoro-phosphate (HBTU) (1.1 equiv), $\mathrm{HOBt}(1.1$ equiv), $N, N-$ diisopropylethylamine (DIEA) (3.5 equiv), DMF, rt, 2 h (79\%); (ii) Piperidine (6 equiv), DMF, rt, 3 h (quant); (iii) Gd-DOTAGA (1.5-1.6 equiv), EDCI $\mathrm{HCl}$ (2.2-3.0 equiv), HOBt (0.3-0.5 equiv), $\mathrm{H}_{2} \mathrm{O}$ or $\mathrm{H}_{2} \mathrm{O} / \mathrm{DMF} \mathrm{pH}$ 6, rt, 4-24 h (41-62\%).

\section{Result and discussion}

\subsection{Affinity and physicochemical properties}

The affinity of the CAs for amyloid aggregates was determined in vitro using [ $\left.{ }^{125} \mathrm{I}\right] 6$-iodo-2-(4'dimethylamino)-phenyl-imidazo[1,2-a]pyridine ([$\left.\left.{ }^{125} \mathrm{I}\right] \mathrm{IMPY}\right)$ binding competition experiments on synthetic $A \beta_{1-42}$ aggregates (Table 1, Supporting Information Fig. S1). This radioligand has several binding sites on the amyloid aggregates and the radioligand competition assays carried out here studied the binding at the BS3 site.[73] Gd(III)-based CAs targeted on A $\beta$ aggregates with a moderate in vitro affinity $(577 \mathrm{nM})$ previously showed to be detectable in vivo by $\mu \mathrm{MRI}$ 
(co-injected with mannitol, $\mathrm{T}_{2} *$ weighted images).[35] CAs were considered to have an interesting affinity when $\mathrm{K}_{\mathrm{i}}<1000$. The affinity of the CAs 28, 29, 37 and $\mathbf{5 2}$ was assessed on human Alzheimer brain homogenates. Due to their absence of affinity, the binding evaluation of these CAs on synthetic $A \beta_{1-42}$ aggregates was not performed. Comparison of both methods to assess the binding affinity of the CAs was carried out with 26, 27 and $\mathbf{3 0}$ and $\mathrm{K}_{\mathrm{i}}$ in the same range were obtained (Supporting Information Table S3). The ratio $\mathrm{K}_{\mathrm{i}(\mathrm{IMPY})} / \mathrm{K}_{\mathrm{i}(\mathrm{CA})} \times 10^{2}$ was used for an accurate comparison of the CA affinities obtained from different experiments. 
Table 1

Evaluation of the CA affinities on amyloid aggregates.

\begin{tabular}{|c|c|c|c|c|c|c|}
\hline $\mathrm{CA}$ & $\begin{array}{l}\text { Gd(III) } \\
\text { chelate }\end{array}$ & Linker & Biovector & $\begin{array}{r}\mathrm{K}_{\mathrm{i}} \\
(\mathrm{nM})\end{array}$ & $\frac{\mathrm{K}_{\mathrm{i} \text { (IMPY) }}}{\mathrm{K}_{\mathrm{i}(\mathrm{CA})}}$ & $-x 10^{2}$ \\
\hline 26 & PCTA & Eta & $\mathrm{S}$ & 217 & & 8.3 \\
\hline 27 & PCTA & Eta & $\mathrm{O}$ & 218 & & 8.2 \\
\hline 28 & DOTA & Eta & $\mathrm{S}$ & $>1000^{a}$ & & - \\
\hline 29 & DOTA & Eta & $\mathrm{O}$ & $>1000^{a}$ & & - \\
\hline 30 & DOTA & Eta & Stilb & $>1000$ & & - \\
\hline 34 & PCTA & Lys & $\mathrm{S}$ & 543 & & 1.7 \\
\hline 35 & PCTA & Lys & $\mathrm{O}$ & $>1000$ & & - \\
\hline 36 & PCTA & Arg & $\mathrm{S}$ & 152 & & 11.8 \\
\hline 46 & PCTA & $\operatorname{Arg}_{3}$ & $\mathrm{~S}$ & 173 & & 5.2 \\
\hline 37 & DOTA & Lys & $\mathrm{S}$ & $>1000^{a}$ & & - \\
\hline 38 & DOTA & Lys & $\mathrm{O}$ & $>1000$ & & - \\
\hline 39 & DOTA & Arg & $\mathrm{S}$ & $>1000$ & & - \\
\hline 51 & DOTA & $\mathrm{SO}_{3}$ & $\mathrm{~S}$ & $>1000$ & & - \\
\hline 47 & DOTA & $\mathrm{Lys}_{3}$ & $\mathrm{~S}$ & 71 & & 25.4 \\
\hline 48 & DOTA & $\operatorname{Arg}_{3}$ & $\mathrm{~S}$ & 131 & & 6.9 \\
\hline 52 & DOTA & $\left(\mathrm{SO}_{3}\right)_{3}$ & $\mathrm{~S}$ & $>1000^{a}$ & & - \\
\hline IMPY & - & - & - & $5^{a}-9-18$ & & 100 \\
\hline
\end{tabular}

$a$ : These CAs were evaluated on human Alzheimer brain homogenates. The biovectors are symbolized by S, O and Stilb, corresponding to the compounds 16, 19 and 22 respectively. The linkers are symbolized by Eta, Lys, $\mathrm{Arg}$ and $\mathrm{SO}_{3}$, corresponding to the ethylamine, lysine, arginine or sulfonate containing linkers respectively. The results are expressed as $\mathrm{K}_{\mathrm{i}(\mathrm{IMPY})} / \mathrm{K}_{\mathrm{i}(\mathrm{CA})}$ $\mathrm{x} 10^{2}$, the higher the ratio is, the higher the affinity is.

The first CAs assessed were Gd(III)-PCTA derivatives. This Gd(III) chelate displays interesting properties which could faciliate its detection in vivo. The PCTA ligand is more rigid and binds the $\mathrm{Gd}^{3+}$ ion via 7 coordination sites, which provides a theoretical interaction of two water molecules with the Gd(III) in the inner sphere of the complex while maintaining a reasonable in vivo stability,[74] leading to higher relaxivity compared to the Gd(III)-DOTA-based CAs 
containing 8 coordination sites and consequently one water molecule in the inner sphere. An ethylamine moiety was used to link the Gd-PCTA12 complex to the biovectors 16 and 19 to obtain the relatively small (MW 904-888 Da) and neutral CAs PCTA-Eta-BTA (26) and PCTAEta-BOX (27). These CAs displayed a high affinity for the amyloid aggregates with a ratio $\mathrm{K}_{\mathrm{i}(\mathrm{IMPY})} / \mathrm{K}_{\mathrm{i}(\mathrm{CA})} \times 10^{2}$ of 8.3 and 8.2 respectively (Fig. 3). However, they showed a very low solubility in water $(<1 \mathrm{mM})$ preventing their use for clinical purposes.
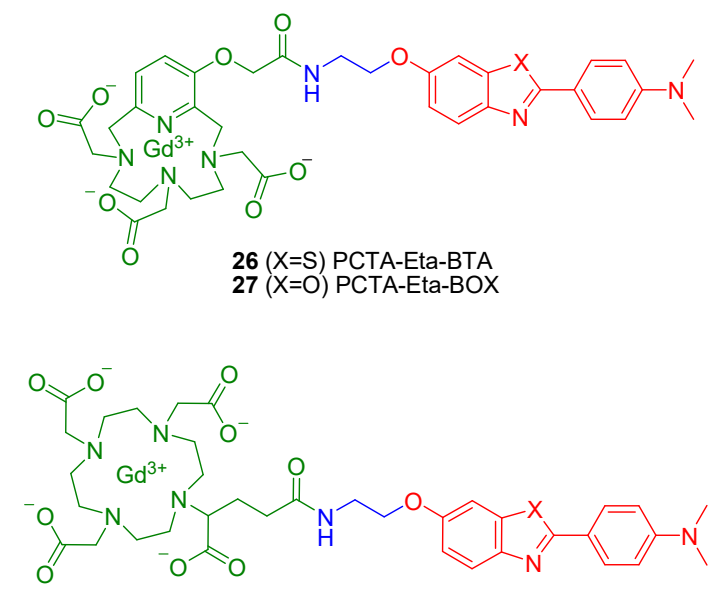

$28(X=S)$ DOTA-Eta-BTA

$29(X=O)$ DOTA-Eta-BOX

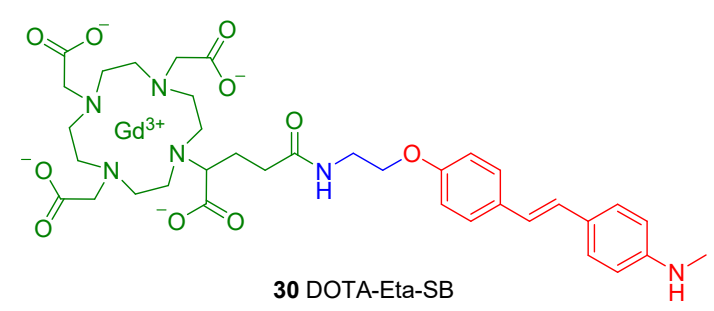

Fig. 3. CAs containing the neutral ethylamine linker. 
Replacement of the neutral Gd-PCTA12 complex by the anionic Gd-DOTAGA was expected to increase the water solubility of the CAs. This complex contains 4 acetate functions and 4 nitrogen atoms which participate in the coordination sphere of the Gd(III). The 8 sites of coordination confer to the Gd-DOTAGA a global anionic charge leading to high hydrosolubility.[63] As expected, the CAs DOTA-Eta-BTA (28) and DOTA-Eta-BOX (29) showed to be more soluble in water (> $3.5 \mathrm{mM}$ ) than the PCTA analogs 26 and 27 (Fig. 3). However, surprisingly these CAs revealed no affinity for the amyloid deposits. Changing the biovector to a different chemical family did not improve the affinity for the amyloid aggregates. Indeed, the Gd(III)-DOTA analog containing the biovector 22 (30, Fig. 3) displayed a high water solubility and no affinity for the amyloid aggregates.

For this reason, the investigation was pursued with Gd(III)-PCTA-based CAs. Modification of the linker was tempted to increase the water solubility of the CAs. Two Gd(III)-PCTA derivatives containing a lysine residue, PCTA-Lys-BTA (34) and PCTA-Lys-BOX (35) (Fig. 4), were synthesized and showed an increased solubility in water (1-2 mM). However, the 2arylbenzoxazole derivative $\mathbf{3 5}$ did not bind the amyloid aggregates while the 2-arylbenzothiazole derivative 34 showed a moderate affinity $\left(\mathrm{K}_{\mathrm{i}(\mathrm{IMPY})} / \mathrm{K}_{\mathrm{i}(\mathrm{CA})} \times 10^{2}=1.7\right)$. Replacement of the lysine residue by an arginine (PCTA-Arg-BTA, 36, Fig. 4) led to affinity for the A $\beta_{1-42}$ aggregates $\left(\mathrm{K}_{\mathrm{i}(\mathrm{IMPY})} / \mathrm{K}_{\mathrm{i}(\mathrm{CA})} \times 10^{2}=11.8\right)$ and moderate solubility in water. 


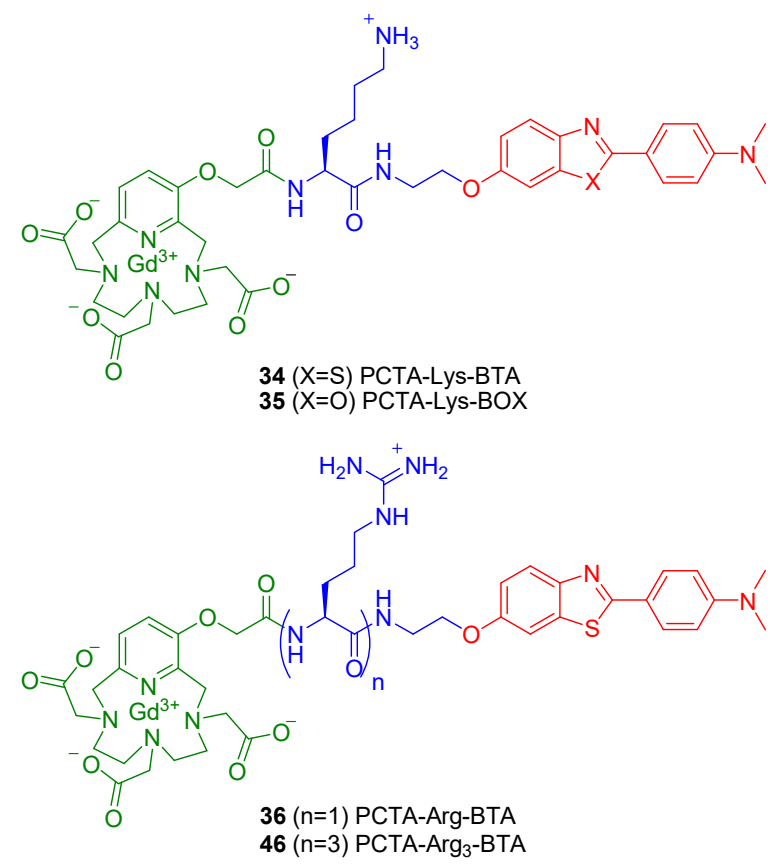

Fig. 4. Gd(III)-PCTA derivative CAs containing a positively charged linker.

An increased linker length to three arginine residues (PCTA-Arg-BTA, 46, Fig. 4) improved slightly the water solubility of the CA while maintaining a similar affinity for the amyloid aggregates $\left(\mathrm{K}_{\mathrm{i}(\mathrm{IMPY})} / \mathrm{K}_{\mathrm{i}(\mathrm{CA})} \times 10^{2}=5.2\right)$. In summary of our investigation on the $\mathrm{Gd}(\mathrm{III})$-PCTAbased CAs, (i) the biovector $\mathbf{1 6}$ is particularly efficient for targeting CAs on amyloid aggregates, (ii) linker charge and length do not influence significantly affinity, (iii) the introduction of a mono or tri-cationic linker in the structure is required to obtain reasonably soluble CAs.

The significant water solubilising effect of the anionic Gd(III)-DOTA moiety was previously observed with CAs DOTA-Eta-BTA (28) and DOTA-Eta-BOX (29), carrying a neutral ethylamine linker. However, these two CAs showed no affinity for the amyloid aggregates. 
Linker and biovector structural variations in the Gd(III)-DOTA-based CA family were then investigated. Cationic and anionic linkers of similar length were used to assess the influence of the charge on the affinity for the amyloid aggregates. For this purpose, the DOTA-Lys-BTA (37), the DOTA-Lys-BOX (38), DOTA-Arg-BTA (39) and the DOTA-SO 3 -BTA (51) were synthesized (Fig. 5).
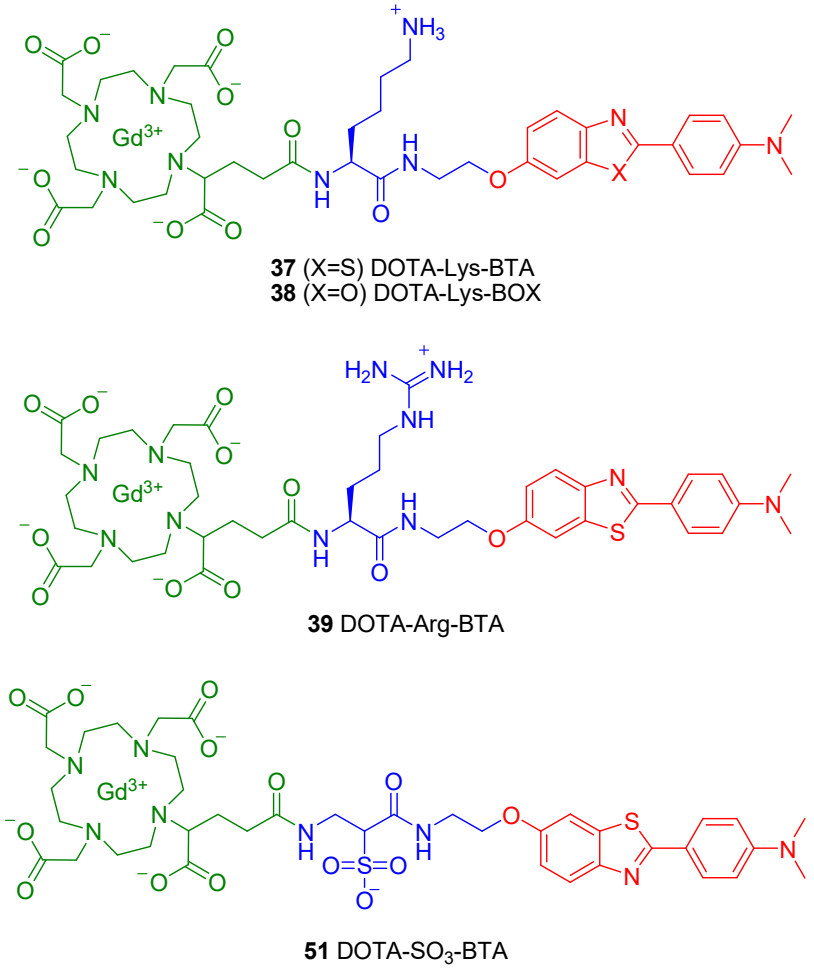

Fig. 5. Gd(III)-DOTA derivative CAs containing a monomeric charged linker.

As expected, all of these CAs were soluble in water $(>2.5-5 \mathrm{mM})$. However, none of them showed affinity for the amyloid aggregates. These results contrast with the observations made 
with the Gd(III)-PCTA analogs $\mathbf{3 4}$ and $\mathbf{3 6}$ which efficiently bound the amyloid aggregates. As previously observed with the CAs $\mathbf{2 8 - 3 0}$, the difference in lypophilicity, charge and/or flexibility of Gd(III)-DOTA moiety compared to Gd(III)-PCTA[62,74] seems to prevent the approach or the binding of the CA on the amyloid aggregates. The negative charge of Gd(III)-DOTA complex favours water solubility but may limit interaction with hydrophobic structures like the amyloid aggregates. On the other hand, the neutral Gd(III)-PCTA complex contains a hydrophobic pyridine moiety, which might favour interaction with these structures. These results encouraged us to synthesize Gd(III)-DOTA-based CAs with longer trimeric charged linkers to separate the Gd(III)-DOTA moiety from the biovector and limit the interaction of the Gd(III) chelate with the amyloid aggregates. For this purpose, the DOTA-Lys_-BTA (47), the DOTA$\mathrm{Arg}_{3}$-BTA (48) and the DOTA-(SO $)_{3}$-BTA (52) CAs (Fig. 6) were synthesized.

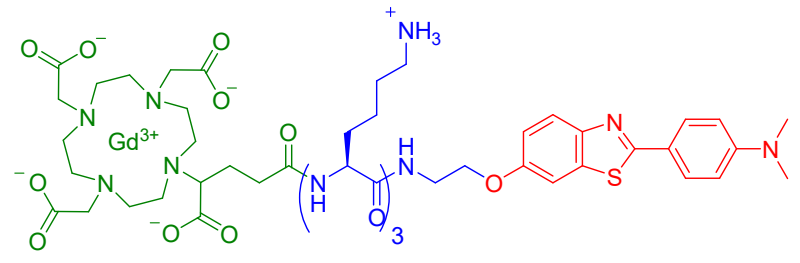

47 DOTA-Lys 3 -BTA

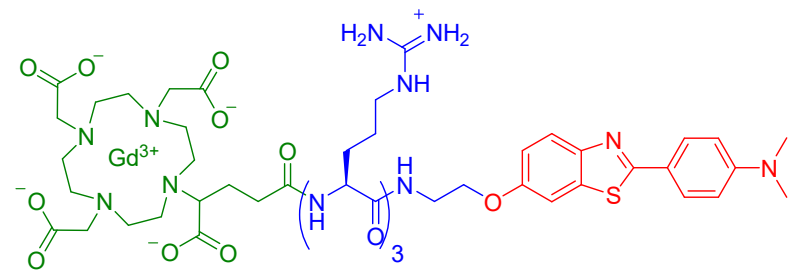

48 DOTA-Arg 3 -BTA

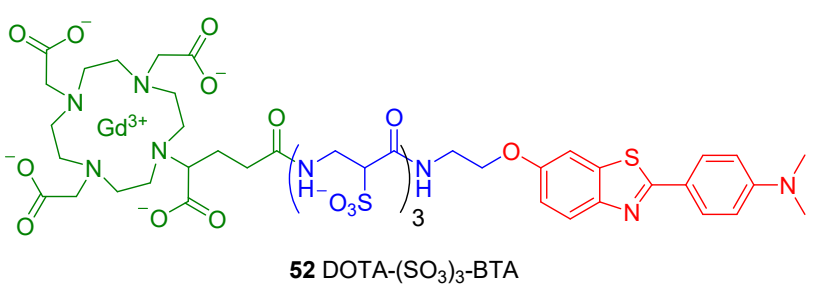

Fig. 6. Gd(III)-DOTA derivative CAs containing a trimeric charged linker. 
In addition to high water solubility, the CAs DOTA-Lys3-BTA (47) and DOTA-Arg3-BTA (48) showed high affinity for the amyloid aggregates $\left(\mathrm{K}_{\mathrm{i}(\mathrm{IMPY})} / \mathrm{K}_{\mathrm{i}(\mathrm{CA})} \times 10^{2}\right.$ of 25.4 and 6.9 respectively). In contrast, the CA DOTA- $\left(\mathrm{SO}_{3}\right)_{3}$-BTA (52) did not bind to the amyloid aggregates, highlighting the importance of linker charge on affinity. Whereas a negative charge present in the close proximity of the biovector is detrimental to the binding on amyloid aggregates, positively charged linkers are compatible with this binding as long as the anionic Gd(III)-DOTA chelate is linked to the biovector by a trimeric peptide.

\subsection{Relaxivity and $C M C$}

The longitudinal $\left(\mathrm{r}_{1}\right)$ and transversal $\left(\mathrm{r}_{2}\right)$ relaxivities of the water soluble CAs were measured under $0.47 \mathrm{~T}$ and $1.5 \mathrm{~T}$ magnetic fields at $37^{\circ} \mathrm{C}$ (Table 2 and Supporting Information Tables S4, S5). These measurements were carried out in water and in reconstructed human serum (seronorm) to assess the influence of binding to blood proteins on relaxivity of the CAs. The relaxivity evaluation of some CAs was also performed in an ion cocktail to estimate the effect of ions present in blood on shielding the paramagnetic center $\mathrm{Gd}(\mathrm{III})$ from water. When the CAs did not form micelles in the concentration range assessed, a linear correlation between the longitudinal $\left(1 / \mathrm{T}_{1}\right)$ or transversal $\left(1 / \mathrm{T}_{2}\right)$ relaxation rates and the concentration of the CA was obtained. In contrast, when the CAs formed micelles, the plot was characterized by two straight lines of different slopes.[75] At low concentration, only the monomeric form of the CA contributed to the relaxation rate measured, whereas at higher concentration, when the CAs started to form micelles, both monomeric and micellar forms of the CA contributed to the relaxation rate, leading to higher relaxivity caused by the motion restriction of the larger micellar 
structures. The straight two lines have their intersection at the critical micelle concentration

$(\mathrm{CMC})$ of the $\mathrm{CA}$. A saturation of the relaxation value at high $\mathrm{CA}$ concentration was sometimes observed for measurements performed in seronorm when the binding sites on the plasma proteins were saturated by the CA.

\section{Table 2}

Measurement of longitudinal relaxivities $r_{1}$ of the CAs under $1.5 \mathrm{~T}$ at $37^{\circ} \mathrm{C}$.

\begin{tabular}{|c|c|c|c|c|c|c|c|c|c|}
\hline \multirow[t]{2}{*}{$\mathrm{CA}$} & \multirow[t]{2}{*}{$\begin{array}{l}\mathrm{Gd}(\mathrm{III}) \\
\text { chelate }\end{array}$} & \multirow[t]{2}{*}{ Linker } & \multirow[t]{2}{*}{ Biovector } & \multicolumn{2}{|c|}{$\begin{array}{c}\mathrm{r}_{1} \text { water } \\
\left(\mathrm{mM}^{-1} \cdot \mathrm{s}^{-1}\right)\end{array}$} & \multirow{2}{*}{$\begin{array}{c}\text { CMC in } \\
\text { water }^{a} \\
(\mathrm{mM})\end{array}$} & \multicolumn{2}{|c|}{$\begin{array}{l}\mathrm{r}_{1} \text { seronorm } \\
\left(\mathrm{mM}^{-1} \cdot \mathrm{s}^{-1}\right)\end{array}$} & \multirow{2}{*}{$\begin{array}{r}\text { CMC in } \\
\text { seronorm }^{a} \\
(\mathrm{mM})\end{array}$} \\
\hline & & & & monomer & micelle & & monomer & micelle & \\
\hline 28 & DOTA & Eta & $\mathrm{S}$ & 6.9 & 11.6 & 1.1 & 19.0 & - & - \\
\hline 29 & DOTA & Eta & $\mathrm{O}$ & 6.5 & 10.7 & 2.0 & 16.1 & - & - \\
\hline 30 & DOTA & Eta & Stilb & 5.5 & 7.8 & 2.6 & 16.1 & - & - \\
\hline 37 & DOTA & Lys & S & 8.1 & 14.5 & 0.6 & 16.4 & - & - \\
\hline 38 & DOTA & Lys & $\mathrm{O}$ & 7.8 & 11.3 & 1.3 & 14.0 & - & \\
\hline 39 & DOTA & Arg & S & 8.0 & 16.5 & 0.7 & 17.2 & - & - \\
\hline 47 & DOTA & $\mathrm{Lys}_{3}$ & S & 8.6 & 12.2 & 2.1 & 13.5 & - & - \\
\hline 48 & DOTA & $\operatorname{Arg}_{3}$ & $\mathrm{~S}$ & 7.1 & 10.5 & 1.1 & 5.7 & 10.7 & 2.3 \\
\hline 51 & DOTA & $\mathrm{SO}_{3}$ & S & 8.7 & - & - & nd & - & - \\
\hline 52 & DOTA & $\left(\mathrm{SO}_{3}\right)_{3}$ & S & 6.6 & - & - & 17.2 & - & \\
\hline 35 & PCTA & Lys & $\mathrm{O}$ & 12.3 & - & - & 21.7 & - & \\
\hline 36 & PCTA & Arg & $\mathrm{S}$ & 11.8 & 17.4 & 0.4 & 22.9 & - & \\
\hline 46 & PCTA & $\operatorname{Arg}_{3}$ & S & $11.7^{b}$ & - & - & 9.0 & 10.5 & 0.3 \\
\hline
\end{tabular}

${ }^{a}$ : CMC was determined under $1.5 \mathrm{~T}$ by $\mathrm{r}_{1}$ measurements. ${ }^{b}$ : determined under $0.47 \mathrm{~T}$. The biovectors are symbolized by $\mathrm{S}, \mathrm{O}$ and Stilb, corresponding to the compounds 16, 19 and 22 respectively. The linkers are symbolized by Eta, Lys, Arg and $\mathrm{SO}_{3}$, corresponding to the ethylamine, lysine, arginine or sulfonate containing linkers respectively.

This study revealed the ability of the Gd(III)-DOTA-based CAs to form micelles in water, characterized by $\mathrm{CMC}$ from $0.6 \mathrm{mM}$ to $2.6 \mathrm{mM}$. This was confirmed by the profile of the plot of 
relaxation against CA concentration and by the higher increase of $r_{2}$ compared to $r_{1}$ after aggregation of the CAs, a known characteristic of micellar systems (cf. Supporting Information Table S4, Fig. S2). The increase of relaxivity by self-assembling of the CAs into micelles was depending on the type of CAs. The relaxivity increase was high for the CAs $\mathbf{3 7}$ and $\mathbf{3 9}$ (79\% to 185\%), slightly lower for the CAs 28 and 29 (65\% to 177\%), moderate for the CAs $\mathbf{3 0}, \mathbf{3 8}, \mathbf{4 7}$, 48 and 36 (40\% to 90\%) or low for the CA 52 (19\% to 27\%) (cf. Supporting Information Fig. S2). Higher relaxivity values may reflect higher water accessibility and/or lower flexibility of the Gd(III) center in the micelles. Only the two CAs carrying sulfonated linker did not self-assemble in water, which could reflect a higher solubility and/or electronic repulsion of this type of linker. The biovector also had a significant influence on CMC of the CAs (28 vs $\mathbf{2 9}$ vs $\mathbf{3 0}$ ), increasing from benzothiazole, benzoxazole to stilbene. This could be explained by an increase in solubility. Indeed, the stilbene, carrying a $N$-monomethylated aniline function, bears a hydrogen bond donor which is absent on the two other $N, N$-dimethylated biovectors, and the benzoxazole moiety is known for its higher solubility compared to the benzothiazole homolog. On the other hand, the Gd(III)-PCTA-based CAs showed a lower tendency to form micelles, potentially caused by the lipophilicity of both the PCTA ligand and the biovector, limiting the amphiphilic character of the CAs. In water, only the Gd(III)-PCTA-based CA 36 formed micelles. The lower relaxivity increase after self-assembling of this CA into micelles compared to the Gd(III)-DOTA analog CA 39 (cf. Supporting Information Fig. S2) could be explained by a decrease of water interaction with $\mathrm{Gd}(\mathrm{III})$ and/or higher flexibility of the micelle.

The $r_{1}$ of Gd(III)-DOTA derivative CAs ranged between 5.5-9.2 $\mathrm{mM}^{-1} \cdot \mathrm{s}^{-1}$ and 7.8-18.3 $\mathrm{mM}^{-1} \cdot \mathrm{s}^{-1}$ for the monomeric and micellar forms respectively in water, and $13.5-29.3 \mathrm{mM}^{-1} \cdot \mathrm{s}^{-1}$ in seronorm 
except for the CA 48 (vide infra) (cf. Supporting Information Table S4, Fig. S3). The high relaxivity of the CAs in the seronorm is explained by a probable binding on plasma proteins.[76] Such an association is expected to reduce the CA mobility, inducing an increase in the rotational correlation time $\tau_{\mathrm{R}}$ and a higher relaxivity. Plasma protein binding could also explain the nonself-assembling of most the CAs into micelles in the seronorm. The Gd(III)-PCTA homolog CAs showed slightly higher $r_{1}$ values, in the range of $11.2-12.7 \mathrm{mM}^{-1} \cdot \mathrm{s}^{-1}$ and $16.6-17.4 \mathrm{mM}^{-1} \cdot \mathrm{s}^{-1}$ for the monomeric and micellar forms respectively in water, and $21.2-33.0 \mathrm{mM}^{-1} . \mathrm{s}^{-1}$ in the seronorm except for the CA 46 (vide infra) (cf. Supporting Information Table S5, Fig. S3). These differences from the Gd(III)-DOTA-based CAs can be rationalized by the different water molecule accessibility and flexibility between the two Gd(III) chelates (see above). No drop in relaxivity was observed for the measurements carried out in ionic solutions, which confirmed that endogenous ions should not interact with Gd(III) and decrease the hydration number of the CAs (cf Supporting Information Tables S4, S4). Besides, for Gd(III)-DOTA-based CAs, a shielding of the anionic charge of the chelate by ions resulted in a decrease of CMC $(\sim 1 \mathrm{mM})$.

Finally, the relaxivity of the CAs synthesized are coherent with their MW, the higher the MW of the CA, the higher $\tau_{\mathrm{R}}$ and relaxivities to expect. The different linkers used do not interact significantly with the paramagnetic center since no relaxivity drop was observed for any of the compounds synthesized. These CAs are susceptible to be detected during an MRI exam if the in vivo $\mathrm{Gd}$ (III) local concentration is sufficient. This study pointed out the CAs $\mathbf{4 6}$ and $\mathbf{4 8}$ (Fig. 4 and Fig. 6) have similar relaxivity in water and in the seronorm, and they are the only CAs which 
formed micelles in seronorm. This suggests a poor binding on plasma protein which could be attributed to the triarginine linker. This may play a crucial role in the biodistribution of the CAs.

\subsection{BBB crossing}

$\mathrm{BBB}$ permeability is a major challenge to overcome to obtain a suitable CA for the detection of amyloid deposits in the brain by MRI. To date, all the CAs described in the literature did not show sufficient BBB permeability to be used for in vivo MRI. Cationic residues were selected to both enhance water solubility and favour BBB crossing. The BBB is particularly difficult to penetrate because of tight junctions formed by epithelial cells, preventing paracellular diffusion, and because of the low presence of pinocytotic vesicles and fenestration in the membrane cells.[77] The different mechanisms known for BBB crossing can be divided into the passive and facilitated diffusion. The former is a non-energy-dependant transport driven by concentration gradient, and the latter is an active transport involving an energy-requiring step. The linkers of the CAs were designed to favour penetration of the BBB through adsorptive-mediated transcytosis. This energy-dependant and nonspecific process enables the binding and uptake of cationic residues to the negative luminal surface of endothelial cells, followed by the exocytosis at the abluminal surface. In contrary to transport across the BBB based on specific interactions with a receptor or a carrier, adsorptive-mediated transcytosis is believed to have lower restriction on the crossing substrates as far as they contain cationic charged moities.[78]

To assess the $\mathrm{BBB}$ permeability of the $\mathrm{CAs}$, an in vitro model of $\mathrm{BBB}$ constituted of a co-culture of rat primary brain capillary endothelial cells and rat glial cells was used. This model is described as one of the most efficient to mimic the in vivo situation.[79-80] None of the CAs 
showed efficient BBB crossing even when they were expected to be protonated at physiological pH (cf. Supporting Information Tables S6). The positive charges introduced on the CAs via the lysine or arginine linkers revealed not to be sufficient to induce adsorptive-mediated transcytosis across the BBB. The presence of a negative charge on the Gd(III) chelate or the relatively large size of the CAs could compete to limit the BBB crossing. The fact that no CAs could cross the BBB in spite of the large CA structural diversity assessed in this study highlights the difficulty to design a chemical structure with the right parameters to detect amyloid deposits by in vivo MRI.

\section{Conclusion}

The SARs highlighted in this paper provide key insights to design Gd-based CAs for the detection of amyloid deposits by MRI. The charge of the Gd(III)-complex is particularly important. An anionic chelate as Gd(III)-DOTA leads to water soluble CAs ( $>2.5-5 \mathrm{mM})$, but the complex needs to be separated from the biovector by a minimal peptidic chain to enable binding on amyloid aggregates. The incompatibility of amyloid aggregate binding with anionic charges was confirmed by using anionic linkers. Most of the CAs containing the Gd(III)-PCTA imaging moiety efficiently bind the amyloid aggregates. However, the water solubility of these CAs is low $(<1-2 \mathrm{mM})$ and the presence of a charged linker is required. A large majority of the CAs forms micelles in water but not in seronorm, suggesting an important binding on plasma proteins. Only the CAs carrying a triarginine linker show the same micelle organisation in water and in seronorm, which suggests a major role of the triarginine moiety on the interaction with plasma proteins. 
Our investigation in the design of Gd-based CAs to detect amyloid aggregates did not lead to the identification of a compound with the characteristics required to make an optimal MRI probe in a clinical context. However, this study describes how structural modifications can efficiently improve hydrosolubility and amyloid aggregate affinity to obtain CAs with interesting characteristics. Based on these results, further investigations will be necessary to optimize the structures for an improved BBB crossing.

\section{Experimental}

\subsection{Chemistry}

\subsubsection{General methods}

All reagents were purchased from Sigma-Aldrich or Acros commercial source with the highest grade commercially available and used without additional purification. Silica gel (Geduran Si 60, 40-63 $\mu \mathrm{m})$ and silanized silica gel (RP-2, 60, 63-200 $\mu \mathrm{m})$ for flash column chromatography were purchased from VWR. Flash column chromatographies with RP-18 were carried out using a CombiFlash device. Thin layer chromatographies were performed using aluminium backed sheets coated with 60F254 silica gel (visualization achieved using a UV lamp at $254 \mathrm{~nm}$, ninhydrin, iodine or ammonium molybdate staining). ${ }^{1} \mathrm{H}$ and ${ }^{13} \mathrm{C}$ NMR spectra were acquired on a Bruker AM400 $400 \mathrm{MHz}$ spectrometer at rt. Chemical shifts $\delta$ are given in ppm with reference to tetramethylsilane (TMS) as the internal standard. Coupling constants $J$ are measured in $\mathrm{Hz}$. Coupling patterns are described by abbreviations: s (singlet), d (doublet), $\mathrm{t}$ (triplet), q (quartet), dd (doublet of doublets), qd (quartet of doublets), m (mutiplet), br (broad). Melting points were 
determined using a Tottoli device. Low-resolution mass spectrometry (LRMS) analyses were performed from ionization by electrospray on positive mode, unless otherwise specified, on a Waters Micromass ZQ2000 mass spectrometer. The mass analyses were made by direct introduction carried out by infusion over 2 min of the sample dissolved in methanol- $\mathrm{HCO}_{2} \mathrm{H}$ $0.1 \%(0.1 \mathrm{mg} / \mathrm{mL})$ within a flow rate of $30 \mu \mathrm{L} / \mathrm{min}$. High-resolution mass spectrometry (HRMS) analyses were acquired on a Thermo Scientific LTQ Orbitrap mass spectrometer. The highperformance liquid chromatography (HPLC) and gas chromatography (GC) methods used are described in the Supporting Information. The water solubility of the CAs was estimated qualitatively by sight using water solutions at a concentration of 1-2 $\mathrm{mM}$ and $2.5-5 \mathrm{mM}$ of Gd(III)-PCTA- and Gd(III)-DOTA-based CAs respectively. A lower concentration was used for the Gd(III)-PCTA derivatives because of the higher relaxivities expected for these CAs. The purity of intermediates was measured by ${ }^{1} \mathrm{H}$ and ${ }^{13} \mathrm{C}$ NMR. The purity of the final CAs was determined by reverse-HPLC and was confirmed $>95 \%$.

\subsubsection{Synthesis}

5.1.2.1. Tri-tert-butyl-1,4,7,10-tetraazacyclododecane-1,4,7-triacetate (11). Cyclen 10 (10.02 g, $58.14 \mathrm{mmol})$ and $\mathrm{AcONa}(14.91 \mathrm{~g}, 181.8 \mathrm{mmol}, 3.1$ equiv) were introduced in dry DMA (164 $\mathrm{mL})$ under argon. $\alpha$-bromo-tert-butylacetate $(26.8 \mathrm{~mL}, 180.0 \mathrm{mmol}, 3.1$ equiv) dissolved in dry DMA (42 mL) was added dropwise at $0{ }^{\circ} \mathrm{C}$ and the reaction was performed at $\mathrm{rt}$ for 3 weeks. The mixture was then cooled to $0{ }^{\circ} \mathrm{C}$ and was filtrated. The precipitate was washed with cold DMA and cold EtOAc. The white solid was then solubilized in DCM and water and was extracted. The organic layer was dried over $\mathrm{Na}_{2} \mathrm{SO}_{4}$ and concentrated to obtain the compound $\mathbf{1 1}$ as a crystalline white powder (11.55 g, $22.47 \mathrm{mmol}, 39 \%) .{ }^{1} \mathrm{H} \mathrm{NMR}\left(\mathrm{CDCl}_{3}, 400 \mathrm{MHz}\right) \delta(\mathrm{ppm}): 3.36(4 \mathrm{H}, \mathrm{s})$, 
$3.28(2 \mathrm{H}, \mathrm{s}), 3.07(4 \mathrm{H}, \mathrm{m}), 2.88(12 \mathrm{H}, \mathrm{m}), 1.45-1.46(27 \mathrm{H}, 2 \mathrm{~s}) .{ }^{13} \mathrm{C} \mathrm{NMR}\left(\mathrm{CDCl}_{3}, 100 \mathrm{MHz}\right) \delta$ (ppm) : 170.7, 169.9, 81.9, 81.7, 58.3, 51.5, 49.6, 47.7, 28.4, 28.3. LRMS ( $m / z)$ : calcd for $\mathrm{C}_{26} \mathrm{H}_{51} \mathrm{~N}_{4} \mathrm{O}_{6}, 515.38\left([\mathrm{M}+\mathrm{H}]^{+}\right)$. Found 515.39. HPLC (method A), $t_{\mathrm{R}} 2.89,3.30$ min. HPLC $\left(\operatorname{method~C)}, t_{\mathrm{R}} 5.81 \min . \mathrm{Mp}: 178-179{ }^{\circ} \mathrm{C}\right.$.

5.1.2.2. 1,4,7,10-tetraazacyclododecane-1,4,7-(tri-tert-butyl-acetate)-10-(diethyl-glutarate) (12). The compound 11 (43.2 g, $84.0 \mathrm{mmol})$ and $\mathrm{K}_{2} \mathrm{CO}_{3}$ (29.2 g, $211 \mathrm{mmol}, 2.5$ equiv) were introduced in acetonitrile $(470 \mathrm{~mL})$ under argon. $\alpha$-bromo-ethylglutarate $(56.5 \mathrm{~g}, 211 \mathrm{mmol}, 2.5$ equiv) was introduced slowly and the reaction was performed at $80^{\circ} \mathrm{C}$ for $28 \mathrm{~h}$. The hot mixture was then filtrated and concentrated. $0.7 \mathrm{~N} \mathrm{HCl}(435 \mathrm{~mL})$ was added and the aqueous layer was washed with toluene $(3 \times 220 \mathrm{~mL})$. After increasing the $\mathrm{pH}$ to 10 , the aqueous layer was extracted with toluene $(3 \times 280 \mathrm{~mL})$. The organic layer was washed with cold water $(2 \times 425 \mathrm{~mL})$, dried over $\mathrm{Na}_{2} \mathrm{SO}_{4}$ and concentrated to obtain the compound 12 as an orange oil (39.5 g, $\left.56.4 \mathrm{mmol}, 67 \%\right)$. ${ }^{1} \mathrm{H} \mathrm{NMR}\left(\mathrm{CDCl}_{3}, 400 \mathrm{MHz}\right) \delta(\mathrm{ppm}): 4.14(4 \mathrm{H}, \mathrm{m}), 3.25(7 \mathrm{H}, \mathrm{m}), 2.80(14 \mathrm{H}, \mathrm{m}), 2.50(4 \mathrm{H}, \mathrm{m})$, 1,91 (2H, m), $1.25(6 \mathrm{H}, \mathrm{m}) .{ }^{13} \mathrm{C} \mathrm{NMR}\left(\mathrm{CDCl}_{3}, 100 \mathrm{MHz}\right) \delta(\mathrm{ppm}): 173.7,173.1,171.2,171.1$, $80.7,63.3,60.3,60.1,56.4,56.1,52.7,52.4,52.2,49.8,30.8,28.3,25.2,14.6,14.3$. HRMS $(m / z)$ : calcd for $\mathrm{C}_{35} \mathrm{H}_{64} \mathrm{~N}_{4} \mathrm{NaO}_{10}, 723.4515\left([\mathrm{M}+\mathrm{Na}]^{+}\right)$. Found 723.4503 .

5.1.2.3. 1,4,7,10-tetraazacyclododecane-1,4,7-triacetic acid-10-glutaric acid. The compound $\mathbf{1 2}$ (35.5 g, $50.7 \mathrm{mmol})$ was dissolved in $12 \mathrm{~N} \mathrm{HCl}(140 \mathrm{~mL})$. The mixture was heated to reflux and stirred for 3 days. The mixture was then adjusted to $\mathrm{pH} 3$ and concentrated to be purified by chromatography on strong basic resin. 1,4,7,10-tetraazacyclododecane-1,4,7-triacetic acid-10glutaric acid (12.4 g, $26.0 \mathrm{mmol}, 51 \%)$ was isolated as an amorphous white powder. LRMS 
$(m / z)$ : calcd for $\mathrm{C}_{19} \mathrm{H}_{33} \mathrm{~N}_{4} \mathrm{O}_{10}, 477.2\left([\mathrm{M}+\mathrm{H}]^{+}\right)$. Found 477.2. HPLC (method $\left.\mathrm{C}\right), t_{\mathrm{R}} 2.07 \mathrm{~min}$. HPLC (method G), $t_{\mathrm{R}} 21.42 \mathrm{~min}$.

\subsubsection{Gadolinium 1,4,7,10-tetraazacyclododecane-1,4,7-triacetic acid-10-glutaric acid (Gd-}

DOTAGA). 1,4,7,10-tetraazacyclododecane-1,4,7-triacetic acid-10-glutaric acid (12.2 g, 20.5 mmol) and $\mathrm{Gd}_{2} \mathrm{O}_{3}\left(3.73 \mathrm{~g}, 10.3 \mathrm{mmol}, 0.5\right.$ equiv) were dissolved in $\mathrm{H}_{2} \mathrm{O}(100 \mathrm{~mL})$. The mixture was heated to $80^{\circ} \mathrm{C}$ for $6 \mathrm{~h}$ maintaining the $\mathrm{pH}$ to $4.5-5.5$. The mixture was then filtrated and concentrated. The crude was purified on silanized silica gel RP-2 $\left(\mathrm{H}_{2} \mathrm{O} / \mathrm{MeOH}\right.$ gradient $)$ and on Chelex resin. The aqueous layer was concentrated by lyophilization and the compound GdDOTAGA (15.1 g, $24.0 \mathrm{mmol}$, 93\%) was isolated as a white slightly electrostatic powder. HRMS $(m / z)$ : calcd for $\mathrm{C}_{19} \mathrm{H}_{28} \mathrm{GdN}_{4} \mathrm{Na}_{2} \mathrm{O}_{10}, 676.0836\left([\mathrm{M}-\mathrm{H}+2 \mathrm{Na}]^{+}\right)$. Found 676.0838. HPLC (method A), $t_{\mathrm{R}} 4.09$ min.

\subsubsection{2-bromo-6-methoxybenzothiazole (14). Cupper (II) bromide (18.28 g, $81.01 \mathrm{mmol}, 1.5$} equiv) and tert-butyl nitrite (10.9 mL, $81.8 \mathrm{mmol}, 1.5$ equiv) were dissolved in anhydrous acetonitrile under argon. 2-amino-6-methoxybenzothiazole (13) $(9.80 \mathrm{~g}, 53.3 \mathrm{mmol})$ was introduced and the mixture was stirred at $\mathrm{rt}$ for 2.5 days, before heating to $65^{\circ} \mathrm{C}$ for $1.5 \mathrm{~h}$. The mixture was then carefully poured in a solution of $3 \mathrm{~N} \mathrm{HCl}$ and was extracted with $\mathrm{Et}_{2} \mathrm{O}(3 \times 250 \mathrm{~mL})$. The organic layer was washed with $3 \mathrm{~N} \mathrm{HCl}(400 \mathrm{~mL})$ and brine $(600 \mathrm{~mL})$ before drying over anhydrous $\mathrm{MgSO}_{4}$ and concentration. The crude was tritured in $\mathrm{MeOH}$ and filtrated. The filtrate was concentrated and purified by flash chromatography on silica gel (cyclohexane/EtOAc 97.5:2.5). The compound 14 (12.01 g, $49.22 \mathrm{mmol}, 92 \%)$ was isolated as a white amorphous powder. ${ }^{1} \mathrm{H}$ NMR $\left(\mathrm{DMSO}-d_{6}, 400 \mathrm{MHz}\right) \delta(\mathrm{ppm}): 7.87(1 \mathrm{H}, \mathrm{d}, J=9.0 \mathrm{~Hz}), 7.69(1 \mathrm{H}, \mathrm{d}, J=2.5 \mathrm{~Hz}), 7.12(1 \mathrm{H}, \mathrm{dd}, J=$ 2.5, $9.0 \mathrm{~Hz}), 3.82(3 \mathrm{H}, \mathrm{s}) .{ }^{13} \mathrm{C}$ NMR (DMSO- $\left.d_{6}, 100 \mathrm{MHz}\right) \delta(\mathrm{ppm}): 157.1,146.3,138.2,135.9$, 
122.8, 116.0, 104.8, 55.8. LRMS $(m / z)$ : calcd for $\mathrm{C}_{8} \mathrm{H}_{7} \mathrm{BrNOS}, 243.94-245.94\left([\mathrm{M}+\mathrm{H}]^{+}\right)$. Found 243.93-245.93. HPLC (method A), $t_{\mathrm{R}} 5.41 \mathrm{~min}$. HPLC (method G), $t_{\mathrm{R}} 37.55 \mathrm{~min}$. HPLC (method $\mathrm{H}), t_{\mathrm{R}} 4.73 \mathrm{~min} . \mathrm{HPLC}(\operatorname{method} \mathrm{I}), t_{\mathrm{R}} 6.62 \mathrm{~min} . \mathrm{GC}(\operatorname{method} \mathrm{L}), t_{\mathrm{R}} 6.72 \mathrm{~min} . \mathrm{Mp}: 92{ }^{\circ} \mathrm{C}$.

5.1.2.6.1. 2-bromo-6-hydroxybenzothiazole (15). The compound 14 (5.369 g, $22.00 \mathrm{mmol})$ was dissolved in anhydrous DCM $(105 \mathrm{~mL})$ under argon. The mixture was cooled to $0{ }^{\circ} \mathrm{C}$ and $\mathrm{BBr}_{3}(1$ $\mathrm{M}$ in DCM, $103 \mathrm{~mL}, 103 \mathrm{mmol}, 4.7$ equiv) was added dropwise. The mixture was stirred at $0{ }^{\circ} \mathrm{C}$ for $10 \mathrm{~min}$ and at $\mathrm{rt}$ for $27 \mathrm{~h}$. The reaction was stopped by carefully pouring the mixture in $\mathrm{MeOH}$ at 0 ${ }^{\circ} \mathrm{C}$ before concentration. The crude oil was mixed in a solution of DCM/EtOAc/MeOH 10:10:1 (15 $\mathrm{mL}$ ) and was filtrated to isolate the precipitate subsequently washed with the solution of DCM/EtOAc/MeOH 10:10:1 (3x25 mL). The compound 15 (5.686 g, $24.71 \mathrm{mmol}$, 94\%, molar purity $87 \%$ by ${ }^{1} \mathrm{H}$ NMR) was obtained as a beige amorphous powder and used for the next step without further treatment. The product contained a minor amount of the by-product 2-bromo-6hydroxy-7-bromobenzothiazole (13\% molar by ${ }^{1} \mathrm{H}$ NMR). ${ }^{1} \mathrm{H}$ NMR (DMSO- $\left.d_{6}, 400 \mathrm{MHz}\right) \delta(\mathrm{ppm})$ : $9.98(1 \mathrm{H}, \mathrm{s}), 7.78(1 \mathrm{H}, \mathrm{d}, J=8.8 \mathrm{~Hz}), 7.40(1 \mathrm{H}, \mathrm{d}, J=2.5 \mathrm{~Hz}), 6.97(1 \mathrm{H}, \mathrm{dd}, J=2.5,8.8 \mathrm{~Hz}) .{ }^{13} \mathrm{C}$ NMR (DMSO- $\left.d_{6}, 100 \mathrm{MHz}\right) \delta(\mathrm{ppm}): 156.0,145.3,138.2,134.6,122.9,116.2,106.7 . \mathrm{LRMS}$ $(m / z)$ : calcd for $\mathrm{C}_{7} \mathrm{H}_{5} \mathrm{BrNOS}, 229.93-231.93\left([\mathrm{M}+\mathrm{H}]^{+}\right)$. Found 229.93-231.93. HPLC (method A), $t_{\mathrm{R}}$ $4.17 \min$. HPLC $(\operatorname{method~G}), t_{\mathrm{R}} 29.68 \mathrm{~min} . \mathrm{HPLC}(\operatorname{method} \mathrm{H}), t_{\mathrm{R}} 5.51 \mathrm{~min} . \mathrm{GC}(\operatorname{method~L}), t_{\mathrm{R}} 7.35$ $\min . \mathrm{GC}(\operatorname{method} \mathrm{M}), t_{\mathrm{R}} 3.00 \mathrm{~min}$.

5.1.2.6.2. By-product 2-bromo-6-hydroxy-7-bromobenzothiazole. ${ }^{1} \mathrm{H}$ NMR (DMSO-d6, $\left.400 \mathrm{MHz}\right) \delta$ (ppm) : $10.90(1 \mathrm{H}, \mathrm{s}), 7.83(1 \mathrm{H}, \mathrm{d}, J=8.8 \mathrm{~Hz}), 7.17(1 \mathrm{H}, \mathrm{d}, J=8.8 \mathrm{~Hz}) .{ }^{13} \mathrm{C}$ NMR (DMSO- $d_{6}, 100$ MHz) $\delta(\mathrm{ppm}): 153.2,144.5,140.8,134.2,122.3,116.4,98.3$. HPLC (method G), $t_{\mathrm{R}} 13.73 \mathrm{~min}$. GC (method L), $t_{\mathrm{R}} 7.64$ min. 
5.1.2.7. 2-(4-N,N-dimethylaminophenyl)-6-hydroxybenzothiazole (16). The compound $\mathbf{1 5}$ (5.194 $\mathrm{g}, 22.58 \mathrm{mmol})$ and 4-aminophenylboronic acid (4.620 g, $28.00 \mathrm{mmol}, 1.2$ equiv) were dissolved in a mixture of $\mathrm{DMF} / \mathrm{K}_{2} \mathrm{CO}_{3} 2 \mathrm{M}$ 65:35 (188 mL) $\left(\mathrm{K}_{2} \mathrm{CO}_{3}, 7.8 \mathrm{mmol}, 6.0\right.$ equiv). After $30 \mathrm{~min}$ under argon bubbling, $\mathrm{Pd}(\mathrm{dppf}) \mathrm{Cl}_{2} . \mathrm{DCM}(816.6 \mathrm{mg}, 1.116 \mathrm{mmol}, 0.05$ equiv) was introduced and the reaction was performed at $80{ }^{\circ} \mathrm{C}$ for $1.5 \mathrm{~h}$. The mixture was then filtered on Celite ${ }^{\circledR}$ and concentrated. The crude was used without further purification for the next step. The product could also be isolated by a precipitation process. In this case, the crude was dissolved in $\mathrm{MeOH}-$ $1 \mathrm{~N} \mathrm{HCl}$ and $\mathrm{Et}_{2} \mathrm{O}$ was introduced to induce the formation of the precipitate isolated by filtration. The precipitate was then poured into water $(20 \mathrm{~mL})$ and $\mathrm{pH}$ was adjusted to 6 . The compound 16 $(2.782 \mathrm{~g}, 10.47 \mathrm{mmol}, 80 \%)$ was isolated by filtration as a brown amorphous powder. ${ }^{1} \mathrm{H}$ NMR $\left(\mathrm{DMSO}-d_{6}, 400 \mathrm{MHz}\right) \delta(\mathrm{ppm}): 9.72(1 \mathrm{H}, \mathrm{s}), 7.81(1 \mathrm{H}, \mathrm{d}, J=8.9 \mathrm{~Hz}), 7.73(2 \mathrm{H}, \mathrm{d}, J=8.7 \mathrm{~Hz})$, $7.33(1 \mathrm{H}, \mathrm{d}, J=2.4 \mathrm{~Hz}), 6.92(1 \mathrm{H}, \mathrm{dd}, J=2.4,8.7 \mathrm{~Hz}), 6.81 \mathrm{ppm}(2 \mathrm{H}, \mathrm{d}, J=9.0 \mathrm{~Hz}), 3.01(6 \mathrm{H}$, s). ${ }^{13} \mathrm{C}$ NMR (DMSO- $\left.d_{6}, 100 \mathrm{MHz}\right) \delta(\mathrm{ppm}): 164.2,155.0,151.8,147.4,135.2,127.9,122.5$, 120.6, 115.5, 111.9, 106.7, 39.5. HRMS (m/z): calcd for $\mathrm{C}_{15} \mathrm{H}_{15} \mathrm{~N}_{2} \mathrm{OS}, 271.0900\left([\mathrm{M}+\mathrm{H}]^{+}\right)$. Found 271.0899. HPLC (method A), $t_{\mathrm{R}} 5.18 \mathrm{~min}$. HPLC (method G), $t_{\mathrm{R}} 33.20 \mathrm{~min}$. HPLC $(\operatorname{method} \mathrm{H}), t_{\mathrm{R}} 7.28 \min . \mathrm{HPLC}(\operatorname{method} \mathrm{J}), t_{\mathrm{R}} 25.07 \min . \mathrm{GC}(\operatorname{method} \mathrm{M}), t_{\mathrm{R}} 8.00 \min$.

5.1.2.8. 2-(4-N,N-dimethylaminophenyl)-6-cyanomethoxybenzothiazole. The compound $\mathbf{1 6}$ and $\mathrm{K}_{2} \mathrm{CO}_{3}(4.773 \mathrm{~g}, 34.58 \mathrm{mmol}, 1.5$ equiv) were introduced in acetone $(305 \mathrm{~mL})$.

Chloroacetonitrile (6.61 mL, $102 \mathrm{mmol}, 4.5$ equiv) was poured in the mixture which was stirred at reflux for $6 \mathrm{~h}$. The hot mixture was filtrated on Celite ${ }^{\circledR}$ and the filtrate was kept $3 \mathrm{~h}$ at $\mathrm{rt}$ to favour the formation of a precipitate isolated by filtration and washed with $\mathrm{Et}_{2} \mathrm{O}$. 2-(4-N,Ndimethylaminophenyl)-6-cyanomethoxybenzothiazole (5.189 g, $16.77 \mathrm{mmol}, 74 \%$ over 2 steps) was obtained as a white amorphous powder. The filtrate could be concentrated and purified by 
chromatography on silica gel (DCM). The product-containing fraction isolated was taken up and mixed into $\mathrm{Et}_{2} \mathrm{O}$ before filtration to get an added amount of 2-(4- $N, N$-dimethylaminophenyl)-6cyanomethoxybenzothiazole. This procedure enhanced the yield to 80-91\%. ${ }^{1} \mathrm{H}$ NMR (DMSO$\left.d_{6}, 400 \mathrm{MHz}\right) \delta(\mathrm{ppm}): 7.90(1 \mathrm{H}, \mathrm{d}, J=8.9 \mathrm{~Hz}), 7.85(2 \mathrm{H}, \mathrm{d}, J=8.8 \mathrm{~Hz}), 7.80(1 \mathrm{H}, \mathrm{d}, J=2.5$ $\mathrm{Hz}), 7.20(1 \mathrm{H}, \mathrm{dd}, J=2.5,8.9 \mathrm{~Hz}), 6.82(2 \mathrm{H}, \mathrm{d}, J=8.8 \mathrm{~Hz}), 5.25(2 \mathrm{H}, \mathrm{s}), 3.02(6 \mathrm{H}, \mathrm{s}) .{ }^{13} \mathrm{C} \mathrm{NMR}$ (DMSO- $\left.d_{6}, 100 \mathrm{MHz}\right) \delta(\mathrm{ppm}): 166.7,153.7,152.1,149.6,135.1,128.3,122.7,120.1,116.6$, 115.5, 111.8, 107.0, 54.2, 39.7. HRMS $(\mathrm{m} / \mathrm{z})$ : calcd for $\mathrm{C}_{17} \mathrm{H}_{16} \mathrm{~N}_{3} \mathrm{OS}, 310.1009\left([\mathrm{M}+\mathrm{H}]^{+}\right)$. Found 310.1001. HPLC (method A), $t_{\mathrm{R}} 6.38 \mathrm{~min}$. HPLC (method G), $t_{\mathrm{R}} 37.87 \mathrm{~min}$. HPLC (method H), $t_{\mathrm{R}} 7.40 \mathrm{~min} . \mathrm{GC}(\operatorname{method} \mathrm{M}), t_{\mathrm{R}} 8.80 \mathrm{~min}$.

\subsubsection{2-(4-N,N-dimethylaminophenyl)-6-cyanomethoxybenzoxazole. 2-(4- $N, N$ -} dimethylaminophenyl)-6-hydroxybenzoxazole (19) (1.809 g, $7.120 \mathrm{mmol})$ and $\mathrm{K}_{2} \mathrm{CO}_{3}(1.091 \mathrm{~g}$, $7.895 \mathrm{mmol}, 1.1$ equiv) were introduced in acetone $(27 \mathrm{~mL})$. Chloroacetonitrile $(1.49 \mathrm{~mL}, 23.1$ mmol, 3.3 equiv) was added and the mixture was stirred at reflux. After 15h, a supplement amount of $\mathrm{K}_{2} \mathrm{CO}_{3}$ (367 mg, $2.66 \mathrm{mmol}, 0.37$ equiv) and chloroacetonitrile (0.46 mL, $7.1 \mathrm{mmol}$, 1.0 equiv) was added and the mixture was stirred at reflux for another $5 \mathrm{~h}$. The hot mixture was filtrated on Celite ${ }^{\circledR}$ and the filtrate was kept $1 \mathrm{~h}$ at $\mathrm{rt}$ to favour the formation of a precipitate filtrated and washed with $\mathrm{Et}_{2} \mathrm{O}$. A white amorphous powder $(1.109 \mathrm{~g}, 3.781 \mathrm{mmol}, 53 \%)$ was isolated. The filtrate could be concentrated and purified by chromatography on silica gel (DCM). The product-containing fraction isolated was taken up and mixed into $\mathrm{Et}_{2} \mathrm{O}$ before filtration to get an added amount of 2-(4- $N, N$-dimethylaminophenyl)-6-cyanomethoxybenzoxazole (547.0 $\mathrm{mg}, 1.865 \mathrm{mmol}$ ). This procedure enhanced the yield to $79 \%$. ${ }^{1} \mathrm{H}$ NMR (DMSO- $\left.d_{6}, 400 \mathrm{MHz}\right) \delta$ (ppm) : $7.97(2 \mathrm{H}, \mathrm{d}, J=9.0 \mathrm{~Hz}), 7.67(1 \mathrm{H}, \mathrm{d}, J=8.7 \mathrm{~Hz}), 7.53(1 \mathrm{H}, \mathrm{d}, J=2.5 \mathrm{~Hz}), 7.07(1 \mathrm{H}, \mathrm{dd}$, $J=2.5,8.7 \mathrm{~Hz}), 6.86(2 \mathrm{H}, \mathrm{d}, J=9.0 \mathrm{~Hz}), 5.26(2 \mathrm{H}, \mathrm{s}), 3.03(6 \mathrm{H}, \mathrm{s}) .{ }^{13} \mathrm{C}$ NMR (DMSO- $d_{6}, 100$ 
MHz) $\delta(\mathrm{ppm}): 163.7,154.3,152.6,150.9,137.6,128.7,120.0,117.0,113.2,112.1,97.9,54.8$, 40.0. HRMS $(m / z)$ : calcd for $\mathrm{C}_{17} \mathrm{H}_{16} \mathrm{~N}_{3} \mathrm{O}_{2}, 294.1237\left([\mathrm{M}+\mathrm{H}]^{+}\right)$. Found 294.1237. HPLC (method C), $t_{\mathrm{R}} 8.76 \mathrm{~min}$. HPLC (method G), $t_{\mathrm{R}} 36.23 \mathrm{~min} . \mathrm{GC}(\operatorname{method} \mathrm{L}), t_{\mathrm{R}} 12.4 \mathrm{~min}$.

5.1.2.10.1. 2-(4-N,N-dimethylaminophenyl)-6-aminoethoxybenzothiazole (23). Method 1. 2-(4$\mathrm{N}, \mathrm{N}$-dimethylaminophenyl)-6-cyanomethoxybenzothiazole (3.353 g, $10.85 \mathrm{mmol})$ was dissolved in anhydrous THF (250 mL). $\mathrm{BH}_{3}$-THF (1 M in DCM, $123.9 \mathrm{~mL}, 123.9 \mathrm{mmol}, 11$ equiv) was added at $\mathrm{rt}$ and the mixture was stirred at $70{ }^{\circ} \mathrm{C}$ for $15 \mathrm{~h}$. The reaction mixture was then poured carefully into $\mathrm{MeOH}$ and stirred for $3 \mathrm{~h}$. After evaporation, the crude was mixed in water and the $\mathrm{pH}$ was increased to $13(2 \mathrm{~N} \mathrm{NaOH})$. The aqueous layer was extracted with DCM, dried over $\mathrm{Na}_{2} \mathrm{SO}_{4}$, concentrated and purified by flash chromatography on silica gel $\left(\mathrm{CHCl}_{3} / \mathrm{MeOH} 95: 5\right.$ to 9:1). The compound $23(1.802 \mathrm{~g}, 5.749 \mathrm{mmol}, 54 \%)$ was isolated as a yellow amorphous powder. ${ }^{1} \mathrm{H}$ NMR (DMSO- $\left.d_{6}, 400 \mathrm{MHz}\right) \delta(\mathrm{ppm}): 7.82(1 \mathrm{H}, \mathrm{d}, J=8.9 \mathrm{~Hz}), 7.81(1 \mathrm{H}, \mathrm{d}, J=8.9$ $\mathrm{Hz}), 7.62(1 \mathrm{H}, \mathrm{d}, J=2.5 \mathrm{~Hz}), 7.07(1 \mathrm{H}, \mathrm{dd}, J=2.5,8.9 \mathrm{~Hz}), 6.81(2 \mathrm{H}, \mathrm{d}, J=8.9 \mathrm{~Hz}), 4.01(2 \mathrm{H}$, $\mathrm{t}, J=5.7 \mathrm{~Hz}), 3.01(6 \mathrm{H}, \mathrm{s}), 2.93(2 \mathrm{H}, \mathrm{t}, J=5.7 \mathrm{~Hz}) .{ }^{13} \mathrm{C}$ NMR (DMSO- $\left.d_{6}, 100 \mathrm{MHz}\right) \delta(\mathrm{ppm})$ : $165.4,156.1,151.9,148.3,135.2,128.1,122.4,120.5,115.6,111.8,105.7,70.2,40.7,39.7$. HRMS $(m / z)$ : calcd for $\mathrm{C}_{17} \mathrm{H}_{20} \mathrm{~N}_{3} \mathrm{OS}, 314.1322\left([\mathrm{M}+\mathrm{H}]^{+}\right)$. Found 314.1317. HPLC (method A), $t_{\mathrm{R}} 3.12 \mathrm{~min} . \mathrm{HPLC}(\operatorname{method} \mathrm{G}), t_{\mathrm{R}} 23.64 \mathrm{~min} . \mathrm{HPLC}(\operatorname{method} \mathrm{J}), t_{\mathrm{R}} 21.83 \mathrm{~min} . \mathrm{GC}(\operatorname{method} \mathrm{M})$, $t_{\mathrm{R}} 9.1 \mathrm{~min}$.

5.1.2.10.2. 2-(4-N,N-dimethylaminophenyl)-6-aminoethoxybenzothiazole (23). Method 2. 2-(4$N, N$-dimethylaminophenyl)-6-( $N$-(tert-butyloxycarbonic acid)-ethoxyamine)-benzothiazole (119 $\mathrm{mg}, 0.285 \mathrm{mmol})$ was dissolved in DCM/TFA 4:1 (2 mL) and stirred at $\mathrm{rt}$ for $1 \mathrm{~h}$. Then the 
mixture was concentrated and mixed in $\mathrm{Et}_{2} \mathrm{O}$ before filtration. The compound $\mathbf{2 3}$ ( $104 \mathrm{mg}, 0.243$ mmol, $85 \%$ ) was isolated as an orange electrostatic powder (triflate salt).

\subsubsection{2-(4-N,N-dimethylaminophenyl)-6-aminoethoxybenzoxazole (24). 2-(4-N,N-} dimethylaminophenyl)-6-cyanomethoxybenzothiazole (1.500 g, $5.119 \mathrm{mmol})$ was dissolved in anhydrous THF (17 mL). BH $_{3}$-THF (1 M in DCM, $56.3 \mathrm{~mL}, 56.3 \mathrm{mmol}, 11$ equiv) was added at $\mathrm{rt}$ and the mixture was stirred at $70{ }^{\circ} \mathrm{C}$ for $2 \mathrm{~h}$. The reaction mixture was then poured carefully into $\mathrm{MeOH}$ and stirred for $15 \mathrm{~min}$. After evaporation, the crude was dissolved in EtOAc/2.5 N $\mathrm{HCl} 2: 1(120 \mathrm{~mL})$ and mixed at $\mathrm{rt}$ for $15 \mathrm{~min}$. The mixture was then cooled to $0{ }^{\circ} \mathrm{C}$ and the $\mathrm{pH}$ was increased to $12(2 \mathrm{~N} \mathrm{NaOH})$. The aqueous layer was extracted with EtOAc $(3 \times 60 \mathrm{~mL})$, dried over $\mathrm{MgSO}_{4}$, concentrated and purified by flash chromatography on silica gel (DCM/MeOH 98:2 to 9:1). The compound 24 (730.0 mg, $2.458 \mathrm{mmol}, 48 \%$ ) was isolated as a black oil. ${ }^{1} \mathrm{H}$ NMR (DMSO- $\left.d_{6}, 400 \mathrm{MHz}\right) \delta(\mathrm{ppm}): 7.93(2 \mathrm{H}, \mathrm{d}, J=9.0 \mathrm{~Hz}), 7.55(1 \mathrm{H}, \mathrm{d}, J=8.5 \mathrm{~Hz}), 7.32$ $(1 \mathrm{H}, \mathrm{d}, J=2.5 \mathrm{~Hz}), 6.94(1 \mathrm{H}, \mathrm{dd}, J=2.5,8.5 \mathrm{~Hz}), 6.83(2 \mathrm{H}, \mathrm{d}, J=9.0 \mathrm{~Hz}), 3.98(2 \mathrm{H}, \mathrm{t}, J=5.7$ Hz), $3.01(6 \mathrm{H}, \mathrm{s}), 2.91(2 \mathrm{H}, \mathrm{t}, J=5.7 \mathrm{~Hz}) .{ }^{13} \mathrm{C}$ NMR (DMSO- $\left.d_{6}, 100 \mathrm{MHz}\right) \delta(\mathrm{ppm}): 162.5$, 156.6, 152.1 $150.8,135.6,128.1,118.8,113.3,112.7,111.8,96.4,70.9,39.7$. HPLC (method C), $t_{\mathrm{R}} 2.98 \mathrm{~min}$. HPLC (method G), $t_{\mathrm{R}} 36.6 \mathrm{~min}$. GC (method L), $t_{\mathrm{R}} 12.43 \mathrm{~min}$. HRMS $(\mathrm{m} / \mathrm{z})$ : calcd for $\mathrm{C}_{17} \mathrm{H}_{20} \mathrm{~N}_{3} \mathrm{O}_{2}, 298.1550\left([\mathrm{M}+\mathrm{H}]^{+}\right)$. Found 298.1545.

\subsubsection{N-(tert-butyloxycarbonic acid)-chloroethylamine. Chloroethylamine chlorhydrate} (2.500 g, $2.134 \mathrm{mmol})$, bis-tert-butyloxycarbonic anhydride (5.589 g, $2.561 \mathrm{mmol}, 1.2$ equiv) and $\mathrm{Et}_{3} \mathrm{~N}$ (6.57 mL, $4.80 \mathrm{mmol}, 2.2$ equiv) were introduced in acetonitrile $(20 \mathrm{~mL})$. The mixture was vigorously stirred at rt for $24 \mathrm{~h}$. Then, the mixture was filtrated on Celite ${ }^{\circledR}$ and concentrated. The crude was mixed with water and extracted with DCM $(3 \times 70 \mathrm{~mL})$. The organic layer was 
dried over $\mathrm{MgSO}_{4}$ and concentrated. $N$-(tert-butyloxycarbonic acid)-chloroethylamine (3.825 g, $2.129 \mathrm{mmol}$, quantitative) was isolated as a translucid oil. ${ }^{1} \mathrm{H}$ NMR (DMSO- $\left.d_{6}, 400 \mathrm{MHz}\right) \delta$ (ppm) : $7.07(1 \mathrm{H}, \mathrm{s}), 3.55(2 \mathrm{H}, \mathrm{t}, J=6.4 \mathrm{~Hz}), 3.22(2 \mathrm{H}, \mathrm{q}, J=6.4 \mathrm{~Hz}), 1.38(9 \mathrm{H}, \mathrm{s}) .{ }^{13} \mathrm{C} \mathrm{NMR}$ (DMSO- $\left.d_{6}, 100 \mathrm{MHz}\right) \delta(\mathrm{ppm}): 155.5,78.0,43.4,42.0,28.2$.

\subsubsection{2-(4- $N, N$-dimethylaminophenyl)-6-(N-(tert-butyloxycarbonic acid)-ethoxyamine)-} benzothiazole. The compound 16 (385.2 g, $1.427 \mathrm{mmol}), N$-(tert-butyloxycarbonic acid)chloroethylamine (309.6 mg, $1.723 \mathrm{mmol}, 1.2$ equiv) and $\mathrm{K}_{2} \mathrm{CO}_{3}(659 \mathrm{mg}, 4.78 \mathrm{mmol}, 3.3$ equiv) were introduced in DMF $(8 \mathrm{~mL})$. The mixture was stirred at $100{ }^{\circ} \mathrm{C}$ for $19 \mathrm{~h}$. Then the mixture was concentrated and purified by flash chromatography on silica gel (cyclohexane/DCM from 1:1 to $0: 1)$. 2-(4-N,N-dimethylaminophenyl)-6-(N-(tert-butyloxycarbonic acid)-ethoxyamine)benzothiazole ( $248 \mathrm{mg}, 0.600 \mathrm{mmol}, 42 \%$ ) was isolated as a yellow amorphous powder. ${ }^{1} \mathrm{H}$ NMR (DMSO- $\left.d_{6}, 400 \mathrm{MHz}\right) \delta(\mathrm{ppm}): 7.83(2 \mathrm{H}, \mathrm{d}, J=8.9 \mathrm{~Hz}), 7.80(1 \mathrm{H}, \mathrm{d}, J=8.9 \mathrm{~Hz}), 7.62$ $(1 \mathrm{H}, \mathrm{d}, J=2.5 \mathrm{~Hz}), 7.05(2 \mathrm{H}, \mathrm{dd}, J=2.5,8.9 \mathrm{~Hz}), 6.80(2 \mathrm{H}, \mathrm{d}, J=8.9 \mathrm{~Hz}), 4.03(2 \mathrm{H}, \mathrm{t}, J=5.8$ $\mathrm{Hz}), 3.33(2 \mathrm{H}, \mathrm{t}, J=5.8 \mathrm{~Hz}), 3.01(6 \mathrm{H}, \mathrm{s}), 1.39(9 \mathrm{H}, \mathrm{s}) .{ }^{13} \mathrm{C}$ NMR (DMSO- $\left.d_{6}, 100 \mathrm{MHz}\right) \delta(\mathrm{ppm})$ : $165.5,155.9,151.9,148.4,135.2,128.1,122.4,120.5,115.6,111.9,105.7,77.8,67.1,39.5$, 28.2. HRMS $(m / z)$ : calcd for $\mathrm{C}_{22} \mathrm{H}_{28} \mathrm{~N}_{3} \mathrm{O}_{3} \mathrm{~S}, 414.1846\left([\mathrm{M}+\mathrm{H}]^{+}\right)$. Found 414.1844. HPLC $(\operatorname{method} \mathrm{A}), t_{\mathrm{R}} 7.24 \min . \mathrm{HPLC}(\operatorname{method} \mathrm{J}), t_{\mathrm{R}} 34.63 \mathrm{~min}$.

5.1.2.14. 4-amino-4'-hydroxy-trans-stilbene (21). 4-nitro-4'-hydroxy-trans-stilbene (20) (9.850 g, $40.83 \mathrm{mmol})$ was introduced in $\mathrm{EtOH}(300 \mathrm{~mL}) . \mathrm{SnCl}_{2}(47.25 \mathrm{~g}, 249.2 \mathrm{mmol}, 6.1$ equiv) and $12 \mathrm{~N} \mathrm{HCl}(17.7 \mathrm{~mL}, 212 \mathrm{mmol}, 5.2$ equiv) were added and the mixture was stirred at reflux for 3 $\mathrm{h}$, before decreasing the temperature to rt keeping stirring for $20 \mathrm{~h}$. Then, the mixture was filtrated and the precipitate was washed with $\mathrm{Et}_{2} \mathrm{O}$. The compound 21 (8.310 g, $\left.37.56 \mathrm{mmol}\right)$ was 
isolated as a red amorphous powder. ${ }^{1} \mathrm{H}$ NMR (DMSO- $\left.d_{6}, 400 \mathrm{MHz}\right) \delta(\mathrm{ppm}): 7.61(2 \mathrm{H}, \mathrm{d}, J=$ $8.6 \mathrm{~Hz}), 7.42(2 \mathrm{H}, \mathrm{d}, J=8.7 \mathrm{~Hz}), 7.29(2 \mathrm{H}, \mathrm{d}, J=8.6 \mathrm{~Hz}), 7.15(1 \mathrm{H}, \mathrm{d}, J=16.4 \mathrm{~Hz}), 7.02(1 \mathrm{H}, \mathrm{d}$, $J=16.4 \mathrm{~Hz}), 6.78(2 \mathrm{H}, \mathrm{d}, J=8.7 \mathrm{~Hz}) .{ }^{13} \mathrm{C} \mathrm{NMR}\left(\mathrm{DMSO}-d_{6}, 100 \mathrm{MHz}\right) \delta(\mathrm{ppm}): 157.5,136.5$, 129.1, 128.0, 127.9, 127.1, 123.9, 122.7, 115.6. LRMS $(\mathrm{m} / \mathrm{z})$ : calcd for $\mathrm{C}_{14} \mathrm{H}_{14} \mathrm{NO}, 212.11$ $\left([\mathrm{M}+\mathrm{H}]^{+}\right)$. Found 212.09. HPLC (method A), $t_{\mathrm{R}} 2.52 \mathrm{~min}$. HPLC (method G), $t_{\mathrm{R}} 19.8-20.8 \mathrm{~min}$.

\subsubsection{4-(N-methylamino)-4'-hydroxy-trans-stilbene (22). The compound 21 (4.80 g, 22.7} mmol) and paraformaldehyde (4.83, $167 \mathrm{mmol}, 8.0$ equiv) were added to a freshly prepared solution of $\mathrm{MeONa}$ in $\mathrm{MeOH}$ under argon $(3.66 \mathrm{~g}, 159 \mathrm{mmol}, 7.0$ equiv of $\mathrm{Na}(\mathrm{s})$ in $65 \mathrm{~mL}$ of $\mathrm{MeOH})$. The mixture was stirred at reflux for $3 \mathrm{~h}$ before being cooled to $0{ }^{\circ} \mathrm{C}$. Then $\mathrm{NaBH}_{4}$ (6.883 g, $182.0 \mathrm{mmol}, 8.0$ equiv) was introduced and the mixture was stirred at reflux for $1 \mathrm{~h}$. Then, $\mathrm{MeOH}$ was evaporated and water was introduced. After adjusting the $\mathrm{pH}$ to 6 , the mixture was filtrated and the precipitate was washed with $\mathrm{Et}_{2} \mathrm{O}$, taken up in $\mathrm{MeOH}$, and dried over $\mathrm{MgSO}_{4}$. The compound $22(3.690 \mathrm{~g}, 16.38 \mathrm{mmol}, 72 \%)$ was isolated as a grey amorphous powder. ${ }^{1} \mathrm{H}$ NMR (DMSO-d6, $\left.400 \mathrm{MHz}\right) \delta(\mathrm{ppm}): 9.38(1 \mathrm{H}, \mathrm{s}), 7.31(2 \mathrm{H}, \mathrm{d}, J=8.6 \mathrm{~Hz}), 7.28$ $(2 \mathrm{H}, \mathrm{d}, J=8.7 \mathrm{~Hz}), 6.85(1 \mathrm{H}, \mathrm{d}, J=16.4 \mathrm{~Hz}), 6.79(1 \mathrm{H}, \mathrm{d}, J=16.4 \mathrm{~Hz}), 6.72(2 \mathrm{H}, \mathrm{d}, J=8.6 \mathrm{~Hz})$, $6.51(2 \mathrm{H}, \mathrm{d}, J=8.7 \mathrm{~Hz}), 5.77(1 \mathrm{H}, \mathrm{br}), 2.68(3 \mathrm{H}, \mathrm{s}) .{ }^{13} \mathrm{C}$ NMR (DMSO- $\left.d_{6}, 100 \mathrm{MHz}\right) \delta(\mathrm{ppm})$ : 156.4, 149.2, 129.0, 127.1, 127.0, 125.9, 125.1, 123.0, 115.4, 111.7, 29.6. HRMS $(\mathrm{m} / \mathrm{z})$ : calcd for $\mathrm{C}_{15} \mathrm{H}_{16} \mathrm{NO}, 226.1226\left([\mathrm{M}+\mathrm{H}]^{+}\right)$. Found 226.1223. HPLC (method A), $t_{\mathrm{R}} 3.54 \mathrm{~min}$. HPLC $(\operatorname{method} \mathrm{G}), t_{\mathrm{R}} 22.97 \min . \mathrm{GC}(\operatorname{method} \mathrm{N}), t_{\mathrm{R}} 6.97 \mathrm{~min}$.

5.1.2.16.1. 4-(N-methylamino)-4'-ethoxyamine-trans-stilbene (25). The compound 22 (1.505 g, $6.680 \mathrm{mmol}), N$-(tert-butyloxycarbonic acid)-chloroethylamine (1.442 g, $8.027 \mathrm{mmol}, 1.2$ equiv) and $\mathrm{K}_{2} \mathrm{CO}_{3}$ (3.087 g, $22.34 \mathrm{mmol}, 3.3$ equiv) were introduced in DMF (8 mL). The mixture was 
stirred at $100{ }^{\circ} \mathrm{C}$ for $42 \mathrm{~h}$. Then the mixture was concentrated and purified by flash chromatography on silica gel (DCM/MeOH from 1:0 to 9:1). 4-( $N$-methylamino)-4' $-N$-(tertbutyloxycarbonic acid)-ethoxyamine-trans-stilbene (567.1 $\mathrm{mg}, 1.539 \mathrm{mmol}, 23 \%)$ was isolated as a yellow amorphous powder. The product was then introduced in DCM/TFA 4:1 (12 mL) and stirred for $1 \mathrm{~h}$ at rt. The crude was mixed with water $\mathrm{pH} 10$ and extracted with DCM. The organic layer was dried over $\mathrm{MgSO}_{4}$, concentrated and purified by flash chromatography on silica gel (DCM/MeOH 9:1). The compound 25 (412.5 mg, $1.537 \mathrm{mmol}$, quant) was isolated as a yellow amorphous powder. ${ }^{1} \mathrm{H}$ NMR (DMSO- $\left.d_{6}, 400 \mathrm{MHz}\right) \delta(\mathrm{ppm}): 8.10(1 \mathrm{H}, \mathrm{br}), 7.47(2 \mathrm{H}, \mathrm{d}$, $J=8.7 \mathrm{~Hz}), 7.34(2 \mathrm{H}, \mathrm{d}, J=8.6 \mathrm{~Hz}), 6.95(4 \mathrm{H}, \mathrm{m}), 6.60(2 \mathrm{H}, \mathrm{d}, J=8.5 \mathrm{~Hz}), 4.17(2 \mathrm{H}, \mathrm{t}, J=5.0$ $\mathrm{Hz}), 3.22(2 \mathrm{H}, \mathrm{m}), 2.71(3 \mathrm{H}, \mathrm{s}) .{ }^{13} \mathrm{C}$ NMR (DMSO- $\left.d_{6}, 100 \mathrm{MHz}\right) \delta(\mathrm{ppm}): 156.8,148.5,131.3$, $127.4,127.1,127.1,122.9,118.2,114.9,112.6,64.4,38.4,30.2$. HRMS $(m / z):$ calcd for $\mathrm{C}_{17} \mathrm{H}_{21} \mathrm{~N}_{2} \mathrm{O}, 269.1648\left([\mathrm{M}+\mathrm{H}]^{+}\right)$. Found 269.1647. HPLC (method A), $t_{\mathrm{R}} 1.12 \mathrm{~min}$. HPLC $(\operatorname{method} \mathrm{G}), t_{\mathrm{R}} 15.90 \mathrm{~min}$

5.1.2.16.2. Protected intermediate. ${ }^{1} \mathrm{H}$ NMR (DMSO- $\left.d_{6}, 400 \mathrm{MHz}\right) \delta(\mathrm{ppm}): 7.42(2 \mathrm{H}, \mathrm{d}, J=$ $8.8 \mathrm{~Hz}), 7.30(2 \mathrm{H}, \mathrm{d}, J=8.7 \mathrm{~Hz}), 7.1-6.4(4 \mathrm{H}, \mathrm{m}), 6.52(2 \mathrm{H}, \mathrm{d}, J=8.7 \mathrm{~Hz}), 3.94(2 \mathrm{H}, \mathrm{m}), 3.28$ $(2 \mathrm{H}, \mathrm{m}), 2.68(3 \mathrm{H}, \mathrm{s}), 1.39(9 \mathrm{H}, \mathrm{s}) .{ }^{13} \mathrm{C}$ NMR $\left(\mathrm{DMSO}-d_{6}, 100 \mathrm{MHz}\right) \delta(\mathrm{ppm}): 157.3,155.7$, $149.4,130.8,127.3,126.9,125.4,124.9,122.5,114.7,111.7,77.8,66.4,38.2,29.6,28.2$. HRMS $(\mathrm{m} / z)$ : calcd for $\mathrm{C}_{22} \mathrm{H}_{29} \mathrm{~N}_{2} \mathrm{O}_{3}, 369.2173\left([\mathrm{M}+\mathrm{H}]^{+}\right)$. Found 369.2174. HPLC (method A), $t_{\mathrm{R}} 6.04$ min. HPLC (method G), $t_{\mathrm{R}} 31.81$ min.

5.1.2.17. $N_{\alpha^{-}}$Fmoc-bis-[N-(tert-butyloxycarbonyl)-L-lysine] (Fmoc-Lys(boc)-Lys(boc)-OH) (41). $N_{\alpha^{-}}$-Fmoc- $N_{\varepsilon}$-(tert-butyloxycarbonyl)-L-lysine (40) (500 mg, $\left.1.05 \mathrm{mmol}\right)$ and NHS (159 mg, 1.36 mmol, 1.3 equiv) were introduced in anhydrous acetonitrile $(3 \mathrm{~mL})$ under argon. Then DCC (242 
$\mathrm{mg}, 1.16 \mathrm{mmol}, 1.1$ equiv) was added and the mixture was stirred at $\mathrm{rt}$ for $23 \mathrm{~h}$ (preparation $\mathbf{A}$ ). In a separate round-bottom flask, ( $N_{\varepsilon}$-tert-butyloxycarbonyl)-L-lysine (263 mg, $1.07 \mathrm{mmol}, 1.0$ equiv) was stirred in a mixture of $\mathrm{NaHCO}_{3} 6.8 \%$ /acetonitrile $1: 2(9 \mathrm{~mL})$ at $0{ }^{\circ} \mathrm{C}$ for $10 \mathrm{~min}$ (preparation B). The preparation $\mathbf{B}$ was then poured dropwise into the preparation $\mathbf{A}$ at $0{ }^{\circ} \mathrm{C}$. The mixture was stirred for $19 \mathrm{~h}$ at $\mathrm{rt}$ before adjusting the $\mathrm{pH}$ to $6(1 \mathrm{~N} \mathrm{HCl})$. Then, acetonitrile was evaporated and the aqueous layer was acidified to $\mathrm{pH} 1(12 \mathrm{~N} \mathrm{HCl})$ before extraction with DCM. $(3 \times 10 \mathrm{~mL})$. The organic layer was washed with water $(1 \times 30 \mathrm{~mL})$ and dried over $\mathrm{MgSO}_{4}$. The crude was purified by flash chromatography on silica gel (DCM/MeOH from 1:0 to 95:5). The compound 41 (560 mg, $0.721 \mathrm{mmol}, 69 \%)$ was obtained as a white amorphous powder. ${ }^{1} \mathrm{H}$ NMR $\left(\mathrm{CD}_{3} \mathrm{OD}, 400 \mathrm{MHz}\right) \delta(\mathrm{ppm}): 7.78(2 \mathrm{H}, \mathrm{d}, J=7.4 \mathrm{~Hz}), 7.66(2 \mathrm{H}, \mathrm{t}, J=7.4 \mathrm{~Hz}), 7.38(2 \mathrm{H}$, t, $J=7.4 \mathrm{~Hz}), 7.30(2 \mathrm{H}, \mathrm{t}, J=7.4 \mathrm{~Hz}), 4.36(2 \mathrm{H}, \mathrm{dd}, J=4.4-6.8 \mathrm{~Hz}), 4.28(1 \mathrm{H}, \mathrm{m}), 4.21(1 \mathrm{H}, \mathrm{t}, J$ $=6.8 \mathrm{~Hz}), 4.11(1 \mathrm{H}, \mathrm{m}), 3.01(4 \mathrm{H}, \mathrm{m}), 1.84-1.67(4 \mathrm{H}, 2 \mathrm{~m}), 1.55-1.30(8 \mathrm{H}, \mathrm{m}), 1.42-1.38(18 \mathrm{H}$, 2s). ${ }^{13} \mathrm{C}$ NMR $\left(\mathrm{CD}_{3} \mathrm{OD}, 100 \mathrm{MHz}\right) \delta(\mathrm{ppm}): 174.5,158.6,145.4,145.1,142.6,128.8,128.2$, $126.3,120.9,79.9,79.8,68.0,56.5,48.4,41.2,41.1,32.9,32.8,31.6,31.5,28.81,28.79,24.2$, 24.1. HRMS $(\mathrm{m} / \mathrm{z})$ : calcd for $\mathrm{C}_{37} \mathrm{H}_{52} \mathrm{~N}_{4} \mathrm{NaO}_{9}, 719.3627\left([\mathrm{M}+\mathrm{Na}]^{+}\right)$. Found 719.3625. HPLC $(\operatorname{method~A}), t_{\mathrm{R}} 7.02 \min . \mathrm{HPLC}(\operatorname{method} \mathrm{C}), t_{\mathrm{R}} 10.24 \min . \mathrm{HPLC}(\operatorname{method~G}), t_{\mathrm{R}} 39.48 \mathrm{~min}$ (activated starting material, $t_{\mathrm{R}} 39.10 \mathrm{~min}$ ).

\subsubsection{8. $N_{\omega^{-}}\left(2,2,4,6,7\right.$-pentamethyldihydrobenzofuran-5-sulfonyl)-L-arginine $\left(\mathrm{H}_{2} \mathrm{~N}\right.$-Arg $(\mathrm{Pbf})$ -} OH). $N_{\alpha}$-Fmoc- $N_{\omega}$-(2,2,4,6,7-pentamethyldihydrobenzofuran-5-sulfonyl)-L-arginine (4.520 g, $6.827 \mathrm{mmol})$ and piperidine $(810 \mu \mathrm{L}, 8.11 \mathrm{mmol}, 1.2$ equiv) were introduced in DMF $(90 \mathrm{~mL})$. The mixture was stirred at $\mathrm{rt}$ for $15 \mathrm{~h}$ before being concentrated, stirred in $\mathrm{Et}_{2} \mathrm{O}(200 \mathrm{~mL})$ for 30 min and then filtrated. $N_{\omega}$-(2,2,4,6,7-pentamethyldihydrobenzofuran-5-sulfonyl)-L-arginine (2.683 g, $6.292 \mathrm{mmol}, 92 \%)$ was isolated as a white amorphous powder. ${ }^{1} \mathrm{H}$ NMR $\left(\mathrm{CD}_{3} \mathrm{OD}, 400\right.$ 
MHz) $\delta(\mathrm{ppm}): 7.90(1 \mathrm{H}, \mathrm{s}), 3.53(1 \mathrm{H}, \mathrm{t}, J=6.4 \mathrm{~Hz}), 3.35(1 \mathrm{H}, \mathrm{s}), 3.20(2 \mathrm{H}, \mathrm{m}), 3.00(2 \mathrm{H}, \mathrm{s})$, $2.57(3 \mathrm{H}, \mathrm{s}), 2.51(3 \mathrm{H}, \mathrm{s}), 2.08(3 \mathrm{H}, \mathrm{s}), 1.83(2 \mathrm{H}, \mathrm{m}), 1.63(2 \mathrm{H}, \mathrm{m}), 1.45(6 \mathrm{H}, \mathrm{s}) .{ }^{13} \mathrm{C} \mathrm{NMR}$ $\left(\mathrm{CD}_{3} \mathrm{OD}, 100 \mathrm{MHz}\right) \delta(\mathrm{ppm}): 159.9,158.2,154.9,139.4,134.3,133.5,126.0,118.5,87.7,55.7$, 44.0, 29.6, 28.7, 26.4, 19.5, 18.3, 15.4, 12.5. LRMS (m/z): calcd for $\mathrm{C}_{19} \mathrm{H}_{31} \mathrm{~N}_{4} \mathrm{O}_{4} \mathrm{~S}, 427.25$ $\left([\mathrm{M}+\mathrm{H}]^{+}\right)$. Found 427.40. HPLC (method D), $t_{\mathrm{R}} 11.10 \mathrm{~min}$.

\subsubsection{9. $N_{\alpha}$-Fmoc-bis-[N $N_{\omega}-(2,2,4,6,7$-pentamethyldihydrobenzofuran-5-sulfonyl)-L-arginine]} (Fmoc-Arg $(\mathrm{Pbf})-\operatorname{Arg}(\mathrm{Pbf})-\mathrm{OH})$ (43). $\mathrm{N}_{\alpha}$-Fmoc- $N_{\omega^{-}}(2,2,4,6,7-$ pentamethyldihydrobenzofuran-5sulfonyl)-L-arginine 42 (4.000 g, $6.042 \mathrm{mmol})$ and NHS (0.717 g, $6.11 \mathrm{mmol}, 1.0$ equiv) were introduced in anhydrous DMF (60 mL) under argon. Then DCC (1.274 g, $6.113 \mathrm{mmol}, 1.0$ equiv) was added to the mixture which was stirred at $\mathrm{rt}$ for $17 \mathrm{~h}$ (preparation $\mathbf{A}$ ). In a separate round-bottom flask, $N_{\omega}$-(2,2,4,6,7-pentamethyldihydrobenzofuran-5-sulfonyl)-L-arginine (2.574 g, $6.045 \mathrm{mmol}, 1.0$ equiv) was stirred in a mixture of $\mathrm{NaHCO}_{3} 6,8 \% / \mathrm{DMF} 2: 3(100 \mathrm{~mL})$ at $0{ }^{\circ} \mathrm{C}$ for 10 min (preparation $\mathbf{B}$ ). The preparation $\mathbf{A}$ was then poured dropwise into the preparation $\mathbf{B}$ at $0{ }^{\circ} \mathrm{C}$. The mixture was stirred for $1 \mathrm{~h}$ at $\mathrm{rt}$. After acidification to $\mathrm{pH} 1(12 \mathrm{~N} \mathrm{HCl})$, the mixture was extracted with DCM $(3 \times 100 \mathrm{~mL})$. The organic layer was washed with water $(1 \times 200 \mathrm{~mL})$ and dried over $\mathrm{MgSO}_{4}$. The compound 43 (4.944 g, $4.677 \mathrm{mmol}, 77 \%$ ) was isolated by flash chromatography on silica gel (DCM/MeOH from 1:0 to 9:1) as a white amorphous powder. ${ }^{1} \mathrm{H}$ NMR $\left(\mathrm{CD}_{3} \mathrm{OD}, 400 \mathrm{MHz}\right) \delta(\mathrm{ppm}): 7.77(2 \mathrm{H}, \mathrm{d}, J=7.4 \mathrm{~Hz}), 7.64(2 \mathrm{H}, \mathrm{t}, J=7.4 \mathrm{~Hz}), 7.36(2 \mathrm{H}$, $\mathrm{t}, J=7.4 \mathrm{~Hz}), 7.28(2 \mathrm{H}, \mathrm{t}, J=7.4 \mathrm{~Hz}), 4.36(3 \mathrm{H}, \mathrm{m}), 4.18(1 \mathrm{H}, \mathrm{m}), 4.11(1 \mathrm{H}, \mathrm{m}), 3.15(4 \mathrm{H}, \mathrm{m})$, $2.96(2 \mathrm{H}, \mathrm{s}), 2.95(2 \mathrm{H}, \mathrm{s}), 2.57(3 \mathrm{H}, \mathrm{s}), 2.55(3 \mathrm{H}, \mathrm{s}), 2.51(3 \mathrm{H}, \mathrm{s}), 2.49(3 \mathrm{H}, \mathrm{s}), 2.06(3 \mathrm{H}, \mathrm{s}), 2.05$ (3H, s, H19), 1.87 (2H, m), 1.78 (2H, m), $1.65(2 \mathrm{H}, \mathrm{m}), 1.55(2 \mathrm{H}, \mathrm{m}), 1.41(3 \mathrm{H}, \mathrm{s}), 1.42(3 \mathrm{H}, \mathrm{s})$. ${ }^{13} \mathrm{C}$ NMR $\left(\mathrm{CD}_{3} \mathrm{OD}, 100 \mathrm{MHz}\right) \delta(\mathrm{ppm}): 175.3,170.7,159.9,159.8,158.4,158.1,145.4,145.1$, $142.6,139.42,139.39,134.3,133.5,128.8,128.2,126.2,126.0,120.9,118.5,87.7,67.9,56.0$, 
48.4, 43.9, 30.8, 30.1, 30.4, 30.3, 28.7, 19.60, 19.58, 18.40, 18.38, 12.5. HRMS (m/z): calcd for $\mathrm{C}_{53} \mathrm{H}_{69} \mathrm{~N}_{8} \mathrm{O}_{11} \mathrm{~S}_{2}, 1057.4522\left([\mathrm{M}+\mathrm{H}]^{+}\right)$. Found 1057.4517. HPLC (method A), $t_{\mathrm{R}} 7.72$ min. HPLC $(\operatorname{method} \mathrm{D}), t_{\mathrm{R}} 4.08 \min . \mathrm{HPLC}(\operatorname{method} \mathrm{G}), t_{\mathrm{R}} 42.41 \mathrm{~min}$.

5.1.2.20. $\alpha$-Sulfo- $\beta$-alanine. Oleum $30 \%(147 \mathrm{~mL})$ was added to $\beta$-alanine ( $9.990 \mathrm{~g}, 112.2$ mmol) in a round-bottom flask at $0{ }^{\circ} \mathrm{C}$. The reaction was carried out for 6 days at $\mathrm{rt}$. Then the mixture was cooled to $0{ }^{\circ} \mathrm{C}$ and $\mathrm{H}_{2} \mathrm{O}(300 \mathrm{~mL})$ was cautiously added. The mixture was kept at 0 ${ }^{\circ} \mathrm{C}$ during 4 days before filtration. The precipitate was dried over $\mathrm{P}_{2} \mathrm{O}_{5} . \alpha$-Sulfo- $\beta$-alanine $(11.33$ $\mathrm{g}, 67.04 \mathrm{mmol}, 60 \%)$ was isolated as a white amorphous powder. ${ }^{1} \mathrm{H}$ NMR $\left(\mathrm{D}_{2} \mathrm{O}, 400 \mathrm{MHz}\right) \delta$ $(\mathrm{ppm}): 4.27(1 \mathrm{H}, \mathrm{t}, J=6.2 \mathrm{~Hz}), 3.67(2 \mathrm{H}, \mathrm{m}) .{ }^{13} \mathrm{C} \mathrm{NMR}\left(\mathrm{D}_{2} \mathrm{O}, 100 \mathrm{MHz}\right) \delta(\mathrm{ppm}): 168.7,61.7$, 37.5. LRMS (negative mode) $(\mathrm{m} / \mathrm{z})$ : calcd for $\mathrm{C}_{3} \mathrm{H}_{6} \mathrm{NO}_{5} \mathrm{~S}, 168.00\left([\mathrm{M}-\mathrm{H}]^{-}\right)$. Found 168.01.) HPLC (method E), $t_{\mathrm{R}} 2.06 \mathrm{~min}$.

5.1.2.21. $N$-(9-Fluorenylmethyloxycarbonyl)- $\alpha$-sulfo- $\beta$-alanine. $\alpha$-Sulfo- $\beta$-alanine (501 mg, 2.96 mmol) was dissolved in a solution of $\mathrm{Na}_{2} \mathrm{CO}_{3} 8.5 \%(7 \mathrm{~mL})$ at $0{ }^{\circ} \mathrm{C}$. A solution of 9fluorenylmethyl $N$-succinimidyl carbonate $(819 \mathrm{mg}, 2.38 \mathrm{mmol}, 0.8$ equiv) in 1,4-dioxane (5 $\mathrm{mL}$ ) was introduced dropwise and the mixture was stirred for $22 \mathrm{~h}$ at $\mathrm{rt}$. Then, the $\mathrm{pH}$ was adjusted to $2(12 \mathrm{~N} \mathrm{HCl})$ before concentration and the crude was dissolved in hot water $\left(50^{\circ} \mathrm{C}\right)$ to be purified by chromatography on silanized silica gel RP-2 $\left(\mathrm{H}_{2} \mathrm{O} / \mathrm{MeOH}\right.$ from 1:0 to 9:1). $N$ (9-Fluorenylmethyloxycarbonyl)- $\alpha$-sulfo- $\beta$-alanine ( $829.1 \mathrm{mg}, 2.120 \mathrm{mmol}, 71 \%$ ) was isolated as a white amorphous powder. ${ }^{1} \mathrm{H}$ NMR (DMSO- $\left.d_{6}, 400 \mathrm{MHz}\right) \delta(\mathrm{ppm}): 7.88(2 \mathrm{H}, \mathrm{d}, J=7.3$ Hz), $7.68(2 \mathrm{H}, \mathrm{m}), 7.41(2 \mathrm{H}, \mathrm{t}, J=7.3 \mathrm{~Hz}), 7.32(2 \mathrm{H}, \mathrm{t}, J=7.3 \mathrm{~Hz}), 4.22(2 \mathrm{H}, \mathrm{m}), 3.62(1 \mathrm{H}, \mathrm{m})$, $3.47(1 \mathrm{H}, \mathrm{m}) .{ }^{13} \mathrm{C}$ NMR (DMSO- $\left.d_{6}, 100 \mathrm{MHz}\right) \delta(\mathrm{ppm}): 169.5,156.0,143.9,140.7,127.7$, 127.2, 125.4, 120.2, 65.6, 65.0, 46.7, 40.3. LRMS (negative mode) $(m / z)$ : calcd for $\mathrm{C}_{18} \mathrm{H}_{16} \mathrm{NO}_{7} \mathrm{~S}$, 
$390.06\left([\mathrm{M}-\mathrm{H}]^{-}\right)$. Found 390.16. HPLC (method A), $t_{\mathrm{R}} 5.02 \mathrm{~min} . \mathrm{HPLC}(\operatorname{method} \mathrm{E}), t_{\mathrm{R}} 24.20$ $\min$. HPLC (method J), $t_{\mathrm{R}} 24.09 \mathrm{~min}$.

\subsubsection{2. $N$-(9-Fluorenylmethyloxycarbonyl)- $\alpha$-sulfo- $\beta$-alaninyl- $\alpha$-sulfo- $\beta$-alanine. $N-(9-$}

Fluorenylmethyloxycarbonyl)- $\alpha$-sulfo- $\beta$-alanine (1.000 g, $2.558 \mathrm{mmol})$, NHS (421.7 mg, 3.591 mmol, 1.4 equiv) and DCC (533.3 mg, $2.559 \mathrm{mmol}, 1.0$ equiv) were introduced in anhydrous DMF (20 mL) under argon. The mixture was stirred at $\mathrm{rt}$ for $19 \mathrm{~h}$ and was then poured dropwise into a stirred solution of $\mathrm{NaHCO}_{3} 6.8 \%(11.5 \mathrm{~mL})$ at $0{ }^{\circ} \mathrm{C}$ containing $\alpha$-sulfo- $\beta$-alanine (429.9 $\mathrm{mg}, 2.544 \mathrm{mmol}, 1.0$ equiv). The mixture was stirred at $\mathrm{rt}$ for $3 \mathrm{~h}$ before adjusting the $\mathrm{pH}$ to 2 $(12 \mathrm{~N} \mathrm{HCl})$. After concentration, the crude was taken up in EtOAc $(3 \times 30 \mathrm{~mL})$ and was decanted to remove the remaining DMF. The oily yellow product was dissolved in $\mathrm{H}_{2} \mathrm{O}$, filtrated to remove $N, N$ '-dicyclohexylurea, and purified by flash chromatography on $\mathrm{RP}-18\left(\mathrm{H}_{2} \mathrm{O} / \mathrm{MeOH}\right.$ from 1:0 to 4:6). $N$-(9-fluorenylmethyloxycarbonyl)- $\alpha$-sulfo- $\beta$-alaninyl- $\alpha$-sulfo- $\beta$-alanine (664.0 $\mathrm{mg}, 1.225 \mathrm{mmol}, 48 \%$, mixture of two racemic diastereomers) was isolated as a white amorphous powder. A small amount of the starting material $N$-(9-fluorenylmethyloxycarbonyl)$\alpha$-sulfo- $\beta$-alanine (103 mg, $0.263 \mathrm{mmol}, 10 \%$ ) could be recovered from the flash chromatography. ${ }^{1} \mathrm{H}$ NMR (DMSO- $\left.d_{6}, 400 \mathrm{MHz}\right) \delta(\mathrm{ppm}): 7.88(2 \mathrm{H}, \mathrm{d}, J=7.4 \mathrm{~Hz}), 7.69(2 \mathrm{H}, \mathrm{d}$, $J=7.4 \mathrm{~Hz}), 7.41(2 \mathrm{H}, \mathrm{t}, J=7.4 \mathrm{~Hz}), 7.33(2 \mathrm{H}, \mathrm{td}, J=1.1-7.4 \mathrm{~Hz}), 4.69$ (br, NH), 4.22-4.21 (3H, 2s), 3.64-3.47 (6H, 2m). ${ }^{13} \mathrm{C}$ NMR (DMSO- $\left.d_{6}, 100 \mathrm{MHz}\right) \delta(\mathrm{ppm}): 169.5,169.4,167.2,155.8$, $143.9,140.7,127.7,127.2,125.4,120.1,65.7,64.9,64.8,64.7,46.7,40.3,40.2,38.34,38.27$. LRMS (negative mode) $(\mathrm{m} / \mathrm{z})$ : calcd for $\mathrm{C}_{21} \mathrm{H}_{21} \mathrm{~N}_{2} \mathrm{O}_{11} \mathrm{~S}_{2}, 541.06\left([\mathrm{M}-\mathrm{H}]^{-}\right)$. Found 541.07. HPLC $(\operatorname{method~} \mathrm{E}), t_{\mathrm{R}} 21.61 \mathrm{~min} . \mathrm{HPLC}(\operatorname{method} \mathrm{J}), t_{\mathrm{R}} 21.05-21.39 \mathrm{~min}$. 


\subsubsection{N-(9-Fluorenylmethyloxycarbonyl)- $\alpha$-sulfo- $\beta$-alaninyl- $\alpha$-sulfo- $\beta$-alaninyl- $\alpha$-sulfo- $\beta$ -}

alanine. $N$-(9-Fluorenylmethyloxycarbonyl)- $\alpha$-sulfo- $\beta$-alaninyl- $\alpha$-sulfo- $\beta$-alanine (467.2 mg, $0.8620 \mathrm{mmol})$ and $O$-( $N$-succinimidyl)-1,1,3,3-tetramethyluronium tetrafluoroborate (TSTU) (259.6 mg, $0.8623 \mathrm{mmol}, 1.0$ equiv) were introduced in anhydrous DMF (11 mL) under argon.

DIEA (453 $\mu \mathrm{L}, 2.59$ mmol, 3.0 equiv) was added and the mixture was stirred at $\mathrm{rt}$ for $17 \mathrm{~h}$. Then the mixture was added dropwise in a stirred solution of $\mathrm{NaHCO}_{3} 6.8 \%(3.9 \mathrm{~mL})$ at $0{ }^{\circ} \mathrm{C}$ containing $\alpha$-sulfo- $\beta$-alanine (160.0 $\mathrm{mg}, 0.9467 \mathrm{mmol}, 1.1$ equiv). The mixture was stirred at $\mathrm{rt}$ for $39 \mathrm{~h}$ before adjusting the $\mathrm{pH}$ to $2(12 \mathrm{~N} \mathrm{HCl})$. After concentration, the crude was taken up in $\mathrm{Et}_{2} \mathrm{O}(3 \times 15 \mathrm{~mL})$ and EtOAc $(1 \times 10 \mathrm{~mL})$ and was decanted to remove the remaining DMF. The oily yellow product was dissolved in $\mathrm{H}_{2} \mathrm{O}$, filtrated to remove the urea derivative, and purified by flash chromatography on RP-18 (TFA 0.1\%/MeOH from 1:0 to 3:7). $N$-(9fluorenylmethyloxycarbonyl)- $\alpha$-sulfo- $\beta$-alaninyl- $\alpha$-sulfo- $\beta$-alaninyl- $\alpha$-sulfo- $\beta$-alanine (292.7 $\mathrm{mg}, 0.4224 \mathrm{mmol}, 49 \%$, mixture of three racemic diastereomers) was isolated as a white amorphous powder. A part of the starting material $N$-(9-fluorenylmethyloxycarbonyl)- $\alpha$-sulfo- $\beta$ alaninyl- $\alpha$-sulfo- $\beta$-alanine $(92.1 \mathrm{mg}, 0.170 \mathrm{mmol}, 20 \%$ ) could be recovered from the flash chromatography. ${ }^{1} \mathrm{H}$ NMR (DMSO- $\left.d_{6}, 400 \mathrm{MHz}\right) \delta(\mathrm{ppm}): 8.16(1 \mathrm{H}, \mathrm{br}), 7.87(2 \mathrm{H}, \mathrm{d}, J=7.5$ Hz), $7.70(2 \mathrm{H}, \mathrm{m}), 7.40(2 \mathrm{H}, \mathrm{t}, J=7.3 \mathrm{~Hz}), 7.33(2 \mathrm{H}, \mathrm{m}), 5.07$ (1H, br), $4.19(3 \mathrm{H}, \mathrm{m}), 3.70-3.30$ $(11 \mathrm{H}, \mathrm{m}), 3.13(2 \mathrm{H}, \mathrm{m}), 1.26-1.25-1.23(15 \mathrm{H}, 3 \mathrm{~s}) .{ }^{13} \mathrm{C}$ NMR (DMSO- $\left.d_{6}, 100 \mathrm{MHz}\right) \delta(\mathrm{ppm})$ : $169.2,155.8,153.5,143.9,140.7,127.6,127.2,125.5,120.1,65.7,65.2,64.9,64.6,53.6,46.6$, 41.9, 38.3, 18.1, 16.8, 12.5. LRMS (negative mode) $\left(\mathrm{m} / \mathrm{z}\right.$ ): calcd for $\mathrm{C}_{24} \mathrm{H}_{26} \mathrm{~N}_{3} \mathrm{O}_{15} \mathrm{~S}_{3}, 692.05$ ([M$\mathrm{H}]^{-}$). Found 692.07. HPLC (method E), $t_{\mathrm{R}}$ 19.58-20.60 min. HPLC (method J), $t_{\mathrm{R}} 18.32-18.51-$ $18.89 \mathrm{~min}$ (activated starting material, $t_{\mathrm{R}} 22.39-22.57 \mathrm{~min}$ ). 


\subsubsection{General Procedure for the Synthesis of Compounds 26 to 39 and 44 to 52}

\subsubsection{Peptidide coupling of the linkers on the ethylamine terminated biovectors}

Detailed descriptions for the synthesis of each compound are included in the Supporting Information (Table S1).

\subsection{Method 1. HOBt (0.2-0.5 equiv), EDCI $\mathrm{HCl}$ (1.1 equiv), and the Fmoc protected} carboxylic acid terminated linker (1.1 to 1.4 equiv) were dissolved in the solvent and stirred at rt for $15 \mathrm{~min}$. The ethylamine terminated biovector previously dissolved in the solvent was then introduced into the mixture. Portions of EDCI HCl (0.5-1 equiv for one portion) were added to the mixture to complete the conversion of the ethylamine terminated biovector. At the end of the reaction, the mixture was concentrated. A precipitation procedure was performed $\left(\mathrm{H}_{2} \mathrm{O}\right)$ or the crude was directly purified by flash chromatography to isolate the modified biovector.

5.1.3.1.2. Method 2. The ethylamine terminated biovector, HBTU (1.1 equiv), HOBT (1.1 equiv) and the Fmoc protected carboxylic acid terminated linker (1.0 equiv) were dissolved in DMF. DIEA (3.5 equiv) was introduced and the mixture was stirred at $\mathrm{rt}$ for $2 \mathrm{~h}$. At the end of the reaction, the mixture was concentrated and the crude was purified by flash chromatography to isolate the modified biovector.

\subsection{Fmoc deprotection of the linkers. The modified biovector was dissolved in DMF and} piperidine (0.2-6 equiv) was introduced in the mixture under stirring. At the end of the reaction, the mixture was concentrated. A precipitation procedure was performed $\left(\mathrm{Et}_{2} \mathrm{O}\right)$ or the crude was directly purified by flash chromatography to isolate the amine terminated biovector. 


\subsubsection{Peptide coupling of the Gd(III) chelates on the amine terminated biovectors.}

Detailed descriptions for the synthesis of each compound are included in the Supporting Information (Table S2).

HOBt (0.3-0.5 equiv), EDCI HCl (1.1 equiv), and the carboxylic acid terminated Gd(III) chelate (Gd-DOTAGA or Gd-PCTA12, 1.0-2.6 equiv) were dissolved in water and stirred at $\mathrm{rt}$ for 15 min. The amine terminated biovector, previously dissolved in an organic solvent (DMF or DMSO), was then introduced dropwise into the mixture. The $\mathrm{pH}$ was maintained to 6 during the reaction. Portions of $\mathrm{EDCI} \mathrm{HCl}$ (0.5-1 equiv for one portion) were added to the mixture to complete the conversion of the amine terminated biovector. At the end of the reaction, the mixture was concentrated. If a lysine or an arginine moiety was contained on the linker of the $\mathrm{CA}$, a deprotection step to remove the boc or the $\mathrm{Pbf}$ protection group respectively was necessary. For both cleavages, the protected CA was dissolved in TFA and stirred for $1-2 \mathrm{~h}$. After concentration of the reaction mixture, cold water was added to the crude and the $\mathrm{pH}$ was quickly adjusted to $6(10 \mathrm{~N} \mathrm{NaOH})$. Finally, a precipitation procedure was performed $\left(\mathrm{Et}_{2} \mathrm{O}\right.$ and/or EtOAc) and/or the crude was purified on reverse phase flash chromatography (RP-2 or RP-18) to isolate the final CA which was lyophilized before storage.

\subsubsection{Characterisations}

5.1.3.3.1. 2-(4-N,N-dimethylaminophenyl)-6-[ethoxyamido-[No-(9-fluorenylmethyloxycarbonyl)$N_{\varepsilon}$-tert-butyloxycarbonyl)-L-lysine]]-benzothiazole. ${ }^{1} \mathrm{H}$ NMR (DMSO-d6, $\left.400 \mathrm{MHz}\right) \delta(\mathrm{ppm})$ : $8.13(1 \mathrm{H}, \mathrm{br}), 7.96(1 \mathrm{H}, \mathrm{s}), 7.88(2 \mathrm{H}, \mathrm{d}, J=7.5 \mathrm{~Hz}), 7.80(3 \mathrm{H}, \mathrm{m}), 7.71(2 \mathrm{H}, \mathrm{m}), 7.60(1 \mathrm{H}, \mathrm{s})$, $7.40(2 \mathrm{H}, \mathrm{m}), 7.34(2 \mathrm{H}, \mathrm{t}, J=7.5 \mathrm{~Hz}), 7.05(1 \mathrm{H}, \mathrm{dd}, J=2.0,9.0 \mathrm{~Hz}), 6.81(2 \mathrm{H}, \mathrm{d}, J=9.1 \mathrm{~Hz})$ $6.70(1 \mathrm{H}, \mathrm{br}), 4.25(2 \mathrm{H}, \mathrm{m}), 4.07(2 \mathrm{H}, \mathrm{t}, J=5.6 \mathrm{~Hz}), 4.00(1 \mathrm{H}, \mathrm{m}), 3.50(3 \mathrm{H}, \mathrm{m}), 3.00(6 \mathrm{H}$, 
s), $2.89(2 \mathrm{H}, \mathrm{m}), 1.58(2 \mathrm{H}, \mathrm{m}), 1.42(13 \mathrm{H}, \mathrm{m}) .{ }^{13} \mathrm{C}$ NMR (DMSO- $\left.d_{6}, 100 \mathrm{MHz}\right) \delta(\mathrm{ppm}): 172.7$, $166.0,156.3,155.9,152.2,148.8,144.2,141.1,135.6,128.4,127.9,127.4,125.7,122.8,120.8$, $120.5,116.0,122.2,106.2,77.7,67.3,65.9,55.1,47.1,40.0,38.6,32.1,29.6,28.6,23.2$. HRMS $(m / z)$ : calcd for $\mathrm{C}_{43} \mathrm{H}_{50} \mathrm{~N}_{5} \mathrm{O}_{6} \mathrm{~S}, 764.3476\left([\mathrm{M}+\mathrm{H}]^{+}\right)$. Found 764.3487 .

5.1.3.3.2. 2-(4-N,N-dimethylaminophenyl)-6-[ethoxyamido-[N$N_{\varepsilon}$-tert-butyloxycarbonyl)-Llysine]]-benzothiazole (31). ${ }^{1} \mathrm{H}$ NMR (DMSO-d $\left.6,400 \mathrm{MHz}\right) \delta(\mathrm{ppm}): 8.13(1 \mathrm{H}, \mathrm{br}), 7.80(3 \mathrm{H}$, m), $7.60(1 \mathrm{H}, \mathrm{s}), 7.05(1 \mathrm{H}, \mathrm{d}, J=7.5 \mathrm{~Hz}), 6.80(2 \mathrm{H}, \mathrm{d}, J=9.0 \mathrm{~Hz}), 6.70(1 \mathrm{H}, \mathrm{br}), 4.10(2 \mathrm{H}, \mathrm{t}, J=$ $5.6 \mathrm{~Hz}), 3.50(2 \mathrm{H}, \mathrm{t}, J=5.6 \mathrm{~Hz}), 3.20(1 \mathrm{H}, \mathrm{m}), 3.00(6 \mathrm{H}, \mathrm{s}), 2.85(2 \mathrm{H}, \mathrm{m}), 1.59-1.25(15 \mathrm{H}, \mathrm{m})$. ${ }^{13} \mathrm{C}$ NMR (DMSO- $\left.d_{6}, 100 \mathrm{MHz}\right) \delta(\mathrm{ppm}): 175.3,165.9,156.8,155.9,152.3,148.8,135.6$, $128.4,122.8,120.8,115.9,112.2,106.1,77.7,67.3,54.7,40.1,38.4,34.8,29.8,28.6,22.9$. HRMS $(m / z)$ : calcd for $\mathrm{C}_{28} \mathrm{H}_{40} \mathrm{~N}_{5} \mathrm{O}_{4} \mathrm{~S}, 542.2796\left([\mathrm{M}+\mathrm{H}]^{+}\right)$. Found 542.2783. HPLC (method A), $t_{\mathrm{R}} 4.34 \mathrm{~min}$. HPLC (method G), $t_{\mathrm{R}} 28.17 \mathrm{~min}$.

5.1.3.3.3. 2-(4-N,N-dimethylaminophenyl)-6-[ethoxyamido-[ $N_{\alpha^{-}}(9-f l u o r e n y l m e t h y l o x y c a r b o n y l)-$ $N_{\varepsilon}$-tert-butyloxycarbonyl)-L-lysine]]-benzoxazole. ${ }^{1} \mathrm{H}$ NMR (DMSO- $\left.d_{6}, 400 \mathrm{MHz}\right) \delta(\mathrm{ppm})$ : $8.11(1 \mathrm{H}, \mathrm{br}), 7.87(6 \mathrm{H}, \mathrm{m}), 7.71(3 \mathrm{H}, \mathrm{m}), 7.42(2 \mathrm{H}, \mathrm{m}), 7.35(2 \mathrm{H}, \mathrm{t}, J=7.5 \mathrm{~Hz}), 6.94(1 \mathrm{H}, \mathrm{dd}, J$ $=2.0,9.0 \mathrm{~Hz}), 6.85(2 \mathrm{H}, \mathrm{d}, J=9.1 \mathrm{~Hz}), 6.71(1 \mathrm{H}, \mathrm{br}), 4.27(2 \mathrm{H}, \mathrm{m}), 4.07(2 \mathrm{H}, \mathrm{m}), 4.00(1 \mathrm{H}, \mathrm{m})$, $3.48(1 \mathrm{H}, \mathrm{m}), 3.38(2 \mathrm{H}, \mathrm{m}), 3.03(6 \mathrm{H}, \mathrm{s}), 2.87(2 \mathrm{H}, \mathrm{m}), 1.60(2 \mathrm{H}, \mathrm{m}), 1.5-1.24(13 \mathrm{H}, \mathrm{m}) .{ }^{13} \mathrm{C}$ NMR (DMSO- $\left.d_{6}, 100 \mathrm{MHz}\right) \delta(\mathrm{ppm}): 172.7,163.0,156.6,156.3,155.9,152.5,151.1,144.2$, $141.1,136.2,128.5,128.0,127.4,125.7,122.5,120.5,119.8,113.2,112.1,96.9,77.7,67.5,66.0$ 55.0, 47.1, 40.0, 38.6, 32.1, 29.6, 28.6, 23.2. HRMS (m/z): calcd for $\mathrm{C}_{43} \mathrm{H}_{50} \mathrm{~N}_{5} \mathrm{O}_{7}, 748.3705$ $\left([\mathrm{M}+\mathrm{H}]^{+}\right)$. Found 748.3707. HPLC $(\operatorname{method} \mathrm{A}), t_{\mathrm{R}} 7.72 \mathrm{~min} . \mathrm{HPLC}(\operatorname{method} \mathrm{G}), t_{\mathrm{R}} 44.53 \mathrm{~min}$. 
5.1.3.3.4. 2-(4-N,N-dimethylaminophenyl)-6-[ethoxyamido-[N$N_{\varepsilon}$-tert-butyloxycarbonyl)-Llysine]]-benzoxazole (32). ${ }^{1} \mathrm{H}$ NMR (DMSO- $\left.d_{6}, 400 \mathrm{MHz}\right) \delta(\mathrm{ppm}): 8.09(1 \mathrm{H}, \mathrm{br}), 7.90(2 \mathrm{H}, \mathrm{d}$, $J=9.0 \mathrm{~Hz}), 7.56(1 \mathrm{H}, \mathrm{d}, J=8.7 \mathrm{~Hz}), 7.36(1 \mathrm{H}, \mathrm{d}, J=2.4 \mathrm{~Hz}), 6.95(1 \mathrm{H}, \mathrm{dd}, J=2.4,8.7 \mathrm{~Hz})$, $6.85(2 \mathrm{H}, \mathrm{d}, J=9.0 \mathrm{~Hz}), 6.70(1 \mathrm{H}, \mathrm{br}), 4.08(2 \mathrm{H}, \mathrm{t}, J=5.6 \mathrm{~Hz}), 3.50(2 \mathrm{H}, \mathrm{t}, J=5.6 \mathrm{~Hz}), 3.41$ $(1 \mathrm{H}, \mathrm{m}), 3.03(6 \mathrm{H}, \mathrm{s}), 2.89(2 \mathrm{H}, \mathrm{m}), 1.56(2 \mathrm{H}, \mathrm{m}), 1.50-1.25(13 \mathrm{H}, \mathrm{m}) .{ }^{13} \mathrm{C}$ NMR (DMSO-d 6 , $100 \mathrm{MHz}) \delta(\mathrm{ppm}): 175.9,163.0,156.6,155.9,152.5,151.2,136.2,128.5,119.2,113.6,113.2$, 112.1, 96.9, 77.7, 67.5, 55.0, 40.2, 40.0, 38.2, 35.2, 29.8, 28.6, 23.0. HRMS (m/z): calcd for $\mathrm{C}_{28} \mathrm{H}_{40} \mathrm{~N}_{5} \mathrm{O}_{5}, 526.3024\left([\mathrm{M}+\mathrm{H}]^{+}\right)$. Found 526.3016. HPLC (method A), $t_{\mathrm{R}} 4.13 \mathrm{~min}$.

5.1.3.3.5. 2-(4-N,N-dimethylaminophenyl)-6-[ethoxyamido-[No-(9-fluorenylmethyloxycarbonyl)$N_{\omega}-(2,2,4,6,7-p e n t a m e t h y l d i h y d r o b e n z o f u r a n-5-s u l f o n y l)-L$-arginine]]-benzothiazole. ${ }^{1} \mathrm{H} \mathrm{NMR}$ (DMSO- $\left.d_{6}, 400 \mathrm{MHz}\right) \delta(\mathrm{ppm}): 8.19(1 \mathrm{H}, \mathrm{br}), 7.88(2 \mathrm{H}, \mathrm{d}, J=7.6 \mathrm{~Hz}), 7.82(2 \mathrm{H}, \mathrm{d}, J=8.9 \mathrm{~Hz})$, $7.78(1 \mathrm{H}, \mathrm{d}, J=8.9 \mathrm{~Hz}), 7.72(2 \mathrm{H}, \mathrm{dd}, J=4.7,7.1 \mathrm{~Hz}), 7.60(1 \mathrm{H}, \mathrm{d}, J=2.4 \mathrm{~Hz}), 7.40(2 \mathrm{H}, \mathrm{t}, J=$ $7.3 \mathrm{~Hz}), 7.31(2 \mathrm{H}, \mathrm{t}, J=7.4 \mathrm{~Hz}), 7.04(1 \mathrm{H}, \mathrm{dd}, J=2.4,8.9 \mathrm{~Hz}), 6.82(2 \mathrm{H}, \mathrm{d}, J=8.9 \mathrm{~Hz}), 4.23$ $(3 \mathrm{H}, \mathrm{m}), 4.02(3 \mathrm{H}, \mathrm{m}), 3.48(2 \mathrm{H}, \mathrm{m}), 3.01(6 \mathrm{H}, \mathrm{s}), 2.91(2 \mathrm{H}, \mathrm{s}), 2.55-2.45(2 \mathrm{H}, \mathrm{m}), 2.48(3 \mathrm{H}, \mathrm{s})$, $2.41(3 \mathrm{H}, \mathrm{s}), 1.98(3 \mathrm{H}, \mathrm{s}), 1.70-1.20(4 \mathrm{H}, \mathrm{m}), 1.37(6 \mathrm{H}, \mathrm{s}) .{ }^{13} \mathrm{C}$ NMR (DMSO- $\left.d_{6}, 100 \mathrm{MHz}\right) \delta$ (ppm) : 172.9, 165.4, 161.3, 157.4, 156.0, 155.9, 151.9, 148.4, 143.7, 141.2, 140.7, 137.2, 135.1, $131.4,128.0,127.6,127.0,125.3,124.3,122.3,120.4,120.0,116.2,115.6,111.8,105.7,86.2$, $66.9,65.6,54.3,46.6,42.7,42.4,39.5,38.2,29.3,28.2,24.0,18.9,17.5,12.2 . \operatorname{HRMS}(\mathrm{m} / \mathrm{z})$ : calcd for $\mathrm{C}_{51} \mathrm{H}_{58} \mathrm{~N}_{7} \mathrm{O}_{7} \mathrm{~S}_{2}, 944.3834\left([\mathrm{M}+\mathrm{H}]^{+}\right)$. Found 944.3834. HPLC (method A), $t_{\mathrm{R}} 8.19$ min. HPLC (method G), $t_{\mathrm{R}} 47.77 \mathrm{~min}$. 


\subsection{2-(4-N,N-dimethylaminophenyl)-6-[ethoxyamido-[N$N_{\omega^{-}}(2,2,4,6,7-$}

pentamethyldihydrobenzofuran-5-sulfonyl)-L-arginine]]-benzothiazole (33). ' $\mathrm{H}$ NMR (DMSO$\left.d_{6}, 400 \mathrm{MHz}\right) \delta(\mathrm{ppm}): 8.26(1 \mathrm{H}, \mathrm{br}), 7.80(3 \mathrm{H}, \mathrm{m}), 7.62(1 \mathrm{H}, \mathrm{d}, J=2.4 \mathrm{~Hz}), 7.06(1 \mathrm{H}, \mathrm{d}, J=8.9$ Hz), $6.81(2 \mathrm{H}, \mathrm{d}, J=8.9 \mathrm{~Hz}), 4.08(2 \mathrm{H}, \mathrm{m}), 3.50(2 \mathrm{H}, \mathrm{m}), 3.38(1 \mathrm{H}, \mathrm{m}), 3.00(6 \mathrm{H}, \mathrm{s}), 2.94(2 \mathrm{H}$, s), 2.55-2.47 (2H, m), $2.48(3 \mathrm{H}, \mathrm{s}), 2.42(3 \mathrm{H}, \mathrm{s}), 1.99(3 \mathrm{H}, \mathrm{s}), 1.70-1.20(4 \mathrm{H}, \mathrm{m}), 1.40(6 \mathrm{H}, \mathrm{s})$. ${ }^{13} \mathrm{C}$ NMR (DMSO- $\left.d_{6}, 100 \mathrm{MHz}\right) \delta(\mathrm{ppm}): 172.9,165.5,162.3,157.4,155.8,151.9,148.4$, $137.3,135.2,131.4,128.1,124.3,122.4,120.4,116.3,115.6,111.8,105.8,86.3,66.9,53.8,42.5$, $39.5,38.1,31.2,28.3,25.2,19.0,17.6,12.3$. We notice signals of $\mathrm{C} 24$ and $\mathrm{C} 18$ are not visible (expected around $141 \mathrm{ppm}$ and 43 ppm respectively). HRMS $(\mathrm{m} / \mathrm{z})$ : calcd for $\mathrm{C}_{36} \mathrm{H}_{48} \mathrm{~N}_{7} \mathrm{O}_{5} \mathrm{~S}_{2}$, $722.3153\left([\mathrm{M}+\mathrm{H}]^{2+}\right)$. Found 722.3163. HPLC (method A), $t_{\mathrm{R}} 4.91$ min. HPLC (method G), $t_{\mathrm{R}}$ $30.79 \mathrm{~min}$.

5.1.3.3.7. 2-(4-N,N-dimethylaminophenyl)-6-[ethoxyamido-[N $N_{\alpha}$ (9-fluorenylmethyloxycarbonyl)tri-[N $N_{\varepsilon^{-}}$(tert-butyloxycarbonyl)-L-lysine]]]-benzothiazole. HRMS $(m / z)$ : calcd for $\mathrm{C}_{65} \mathrm{H}_{90} \mathrm{~N}_{9} \mathrm{O}_{12} \mathrm{~S}$, 1220.6435 $\left([\mathrm{M}+\mathrm{H}]^{+}\right)$. Found 1220.6439. HPLC (method A), $t_{\mathrm{R}} 8.76 \mathrm{~min}$.

5.1.3.3.8. 2-(4-N,N-dimethylaminophenyl)-6-[ethoxyamido-[tri-[N-(tert-butyloxycarbonyl)-Llysine]]]-benzothiazole (44). HRMS (m/z): calcd for $\mathrm{C}_{50} \mathrm{H}_{80} \mathrm{~N}_{9} \mathrm{O}_{10} \mathrm{~S}, 998.5743\left([\mathrm{M}+\mathrm{H}]^{+}\right)$. Found 998.5748. HPLC (method A), $t_{\mathrm{R}} 5.70 \mathrm{~min}$. HPLC (method C), $t_{\mathrm{R}} 7.88 \mathrm{~min}$. HPLC (method G), $t_{\mathrm{R}}$ $31.83 \mathrm{~min}$.

\subsection{2-(4-N,N-dimethylaminophenyl)-6-[ethoxyamido-tri-[No-(9-}

fluorenylmethyloxycarbonyl)- $N_{\omega}-(2,2,4,6,7-$ pentamethyldihydrobenzofuran-5-sulfonyl)-Larginine]]-benzothiazole. HRMS (m/z): calcd for $\mathrm{C}_{89} \mathrm{H}_{113} \mathrm{~N}_{15} \mathrm{NaO}_{15} \mathrm{~S}_{4}, 1782.7316\left([\mathrm{M}+\mathrm{Na}]^{+}\right)$. Found 1782.7282. HPLC (method A), $t_{\mathrm{R}} 9.32 \mathrm{~min} . \mathrm{HPLC}(\operatorname{method} \mathrm{G}), t_{\mathrm{R}} 52.85 \mathrm{~min}$. 


\subsection{2-(4-N,N-dimethylaminophenyl)-6-[ethoxyamido-tri-[N$N_{\omega}-(2,2,4,6,7-$}

pentamethyldihydrobenzofuran-5-sulfonyl)-L-arginine]]-benzothiazole (45). HRMS ( $\mathrm{m} / \mathrm{z})$ : calcd for $\mathrm{C}_{74} \mathrm{H}_{103} \mathrm{~N}_{15} \mathrm{NaO}_{13} \mathrm{~S}_{4}, 1560.6635\left([\mathrm{M}+\mathrm{Na}]^{+}\right)$. Found 1560.6606. HPLC (method B), $t_{\mathrm{R}} 6.57$ min. HPLC (method G), $t_{\mathrm{R}} 35.16$ min.

5.1.3.3.11. 2-(4-N,N-dimethylaminophenyl)-6-[ethoxyamido-[N-(9-fluorenylmethyloxycarbonyl)$\alpha$-sulfo- $\beta$-alanine]]-benzothiazole. ${ }^{1} \mathrm{H}$ NMR (DMSO- $\left.d_{6}, 400 \mathrm{MHz}\right) \delta(\mathrm{ppm}): 8.06(1 \mathrm{H}, \mathrm{m}), 7.87$ $(2 \mathrm{H}, \mathrm{d}, J=7.3 \mathrm{~Hz}), 7.81(2 \mathrm{H}, \mathrm{d}, J=8.0 \mathrm{~Hz}), 7.78(1 \mathrm{H}, \mathrm{d}, J=9.7 \mathrm{~Hz}), 7.66(2 \mathrm{H}, \mathrm{d}, J=7.2 \mathrm{~Hz})$ $7.59(1 \mathrm{H}, \mathrm{s}), 7.39(2 \mathrm{H}, \mathrm{t}, J=7.4 \mathrm{~Hz}), 7.30(2 \mathrm{H}, \mathrm{t}, J=7.5 \mathrm{~Hz}), 7.06(2 \mathrm{H}, \mathrm{m}), 6.81(2 \mathrm{H}, \mathrm{d}, J=8.0$ $\mathrm{Hz}), 4.19(3 \mathrm{H}, \mathrm{m}), 4.03(2 \mathrm{H}, \mathrm{t}, J=5.6 \mathrm{~Hz}), 3.49(5 \mathrm{H}, \mathrm{m}), 3.01(6 \mathrm{H}, \mathrm{s}) .{ }^{13} \mathrm{C}$ NMR (DMSO- $d 6,100$ MHz) $\delta(\mathrm{ppm}): 167.7,165.5,155.9,155.7,151.9,148.4,143.8,140.7,135.2,128.1,127.6$, 127.1, 125.3, 122.4, 120.1, 115.7, 111.9, 105.9, 67.0, 65.6, 64.9, 46.7, 40.2, 38.2. HRMS $(\mathrm{m} / \mathrm{z})$ : calcd for $\mathrm{C}_{34} \mathrm{H}_{35} \mathrm{~N}_{3} \mathrm{O}_{10} \mathrm{~S}_{2}, 709.1758\left([\mathrm{M}+\mathrm{H}]^{+}\right)$. Found 709.1751. HPLC (method E), $t_{\mathrm{R}} 35.28$ min. HPLC (method J), $t_{\mathrm{R}} 29.73$ min.

\subsection{2-(4-N,N-dimethylaminophenyl)-6-[ethoxyamido-( $\alpha$-sulfo- $\beta$-alanine)]-benzothiazole} (49). ${ }^{1} \mathrm{H}$ NMR (DMSO- $\left.d_{6}, 400 \mathrm{MHz}\right) \delta(\mathrm{ppm}): 7.83(1 \mathrm{H}, \mathrm{d}, J=8.9 \mathrm{~Hz}), 7.81(2 \mathrm{H}, \mathrm{t}, J=9.0 \mathrm{~Hz})$, $7.64(1 \mathrm{H}, \mathrm{d}, J=2.6 \mathrm{~Hz}), 7.08(1 \mathrm{H}, \mathrm{d}, J=8.9 \mathrm{~Hz}), 6.81(2 \mathrm{H}, \mathrm{d}, J=9.0 \mathrm{~Hz}), 4.06(2 \mathrm{H}, \mathrm{m}, J=5.6$ $\mathrm{Hz}), 3.70-3.15(5 \mathrm{H}, \mathrm{m}), 3.05(4 \mathrm{H}, \mathrm{br}), 3.01(6 \mathrm{H}, \mathrm{s}), 2.80(4 \mathrm{H}, \mathrm{br}), 1.50(2 \mathrm{H}, \mathrm{br}) .{ }^{13} \mathrm{C} \mathrm{NMR}$ (DMSO- $\left.d_{6}, 100 \mathrm{MHz}\right) \delta(\mathrm{ppm}): 168.1,165.5,155.8,151.9,148.5,135.1,128.1,122.4,120.5$, 115.7, 111.8, 106.0, 67.0, 66.2, 45.6, 40.6, 38.2, 24.9, 23.6. HRMS ( $m / z)$ : calcd for $\mathrm{C}_{20} \mathrm{H}_{25} \mathrm{~N}_{4} \mathrm{O}_{5} \mathrm{~S}_{2}, 465.1261\left([\mathrm{M}+\mathrm{H}]^{+}\right)$. Found 465.1259. HPLC (method A), $t_{\mathrm{R}} 4.34 \mathrm{~min}$. HPLC $(\operatorname{method} \mathrm{J}), t_{\mathrm{R}} 21.29 \mathrm{~min}$. 
5.1.3.3.13. 2-(4-N,N-dimethylaminophenyl)-6-[ethoxyamido-[N-(9-fluorenylmethyloxycarbonyl)$\alpha$-sulfo- $\beta$-alaninyl- $\alpha$-sulfo- $\beta$-alaninyl- $\alpha$-sulfo- $\beta$-alanine]]-benzothiazole. ${ }^{1} \mathrm{H}$ NMR (DMSO- $d_{6}$, $400 \mathrm{MHz}) \delta(\mathrm{ppm}): 8.16(3 \mathrm{H}, \mathrm{br}), 7.81(5 \mathrm{H}, \mathrm{m}), 7.68(3 \mathrm{H}, \mathrm{m}), 7.39(2 \mathrm{H}, \mathrm{m}), 7.33(2 \mathrm{H}, \mathrm{m}), 7.08$ $(1 \mathrm{H}, \mathrm{m}), 6.79(2 \mathrm{H}, \mathrm{d}, J=9.0 \mathrm{~Hz}), 4.19(3 \mathrm{H}, \mathrm{m}), 4.04(2 \mathrm{H}, \mathrm{m}), 3.80-3.30(17 \mathrm{H}, \mathrm{m}), 3.12(6 \mathrm{H}, \mathrm{qd}$, $J=4.3 \mathrm{~Hz}), 3.00(6 \mathrm{H}, \mathrm{s}), 1.28(45 \mathrm{H}, \mathrm{m}) .{ }^{13} \mathrm{C} \mathrm{NMR}\left(\mathrm{DMSO}-d_{6}, 100 \mathrm{MHz}\right) \delta(\mathrm{ppm}): 167.81$, $167.76,167.4,167.2,167.0,166.6,165.5,155.9,155.8,151.9,148.4,143.9,140.6,135.2,128.1$, $127.6,127.2,125.5,122.3,120.6,120.0,115.7,111.9,105.9,66.8,66.6,65.2,65.0,64.6,64.5$, 65.7, 64.7, 53.6, 46.6, 41.9, 41.3, 39.5, 38.0, 18.1, 16.7, 12.5. HRMS (negative mode) $(\mathrm{m} / \mathrm{z})$ : calcd for $\mathrm{C}_{41} \mathrm{H}_{45} \mathrm{~N}_{6} \mathrm{O}_{15} \mathrm{~S}_{4}, 987.1675\left([\mathrm{M}-\mathrm{H}]^{-}\right)$. Found 987.1639. HPLC (method E), $t_{\mathrm{R}} 27.48$ min. HPLC (method J), $t_{\mathrm{R}} 23.68-23.85 \mathrm{~min}$.

\subsection{2-(4-N,N-dimethylaminophenyl)-6-[ethoxyamido-( $\alpha$-sulfo- $\beta$-alaninyl- $\alpha$-sulfo- $\beta$ -} alaninyl- $\alpha$-sulfo- $\beta$-alanine)]-benzothiazole (50). ${ }^{1} \mathrm{H}$ NMR (DMSO- $\left.d_{6}, 400 \mathrm{MHz}\right) \delta(\mathrm{ppm}): 8.06$ (2H, br), $7.82(6 \mathrm{H}, \mathrm{m}), 7.67(1 \mathrm{H}, \mathrm{s}), 7.10(1 \mathrm{H}, \mathrm{d}, J=8.8 \mathrm{~Hz}), 6.80(2 \mathrm{H}, \mathrm{d}, J=8.9 \mathrm{~Hz}), 4.06(2 \mathrm{H}$, m), 3.85-3.10 (11H, m), $3.00(14 \mathrm{H}, \mathrm{m}), 1.63(8 \mathrm{H}, \mathrm{br}), 1.53(4 \mathrm{H}, \mathrm{br}) .{ }^{13} \mathrm{C}$ NMR (DMSO-d, 100 MHz) $\delta(\mathrm{ppm}): 167.2,167.1,165.9,165.5,155.9,151.9,148.5,135.2,128.1,122.4,120.5$, $115.7,111.9,106.0,65.0,64.6,64.5,64.34,64.26,61.64,61.59,43.8,40.1,39.5,38.2,22.2$, 21.7. HRMS (negative mode) $(\mathrm{m} / z)$ ): calcd for $\mathrm{C}_{26} \mathrm{H}_{32} \mathrm{~N}_{6} \mathrm{NaO}_{13} \mathrm{~S}_{4}, 787.0813\left([\mathrm{M}-2 \mathrm{H}+\mathrm{Na}]^{-}\right)$. Found 787.0785. HPLC (method E), $t_{\mathrm{R}}$ 21.31-21.67 min. HPLC (method J), $t_{\mathrm{R}} 17.28-17.49$ min.

5.1.3.3.15. 26. $\mathrm{HRMS}(\mathrm{m} / \mathrm{z})$ : calcd for $\mathrm{C}_{36} \mathrm{H}_{40} \mathrm{GdN}_{7} \mathrm{NaO}_{9} \mathrm{~S}, 927.1741\left([\mathrm{M}+\mathrm{Na}]^{+}\right)$. Found 927.1743. HPLC (method A), $t_{\mathrm{R}} 4.16 \mathrm{~min} . \mathrm{HPLC}(\operatorname{method} \mathrm{G}), t_{\mathrm{R}} 26.34 \mathrm{~min}$.

5.1.3.3.16. 27. HRMS $(\mathrm{m} / \mathrm{z})$ : calcd for $\mathrm{C}_{36} \mathrm{H}_{40} \mathrm{GdN}_{7} \mathrm{NaO}_{10}, 911.1970\left([\mathrm{M}+\mathrm{Na}]^{+}\right)$. Found 911.1975. HPLC (method A), $t_{\mathrm{R}} 4.03 \mathrm{~min} . \mathrm{HPLC}(\operatorname{method} \mathrm{G}), t_{\mathrm{R}} 25.64 \mathrm{~min}$. 
5.1.3.3.17. 28. HRMS ( $\mathrm{m} / \mathrm{z})$ : calcd for $\mathrm{C}_{36} \mathrm{H}_{46} \mathrm{GdN}_{7} \mathrm{Na}_{2} \mathrm{O}_{10} \mathrm{~S}, 486.1026\left([\mathrm{M}+2 \mathrm{Na}]^{2+}\right)$. Found 486.1020. HPLC (method A), $t_{\mathrm{R}} 4.74 \mathrm{~min} . \mathrm{HPLC}(\operatorname{method} \mathrm{G}), t_{\mathrm{R}} 30.08 \mathrm{~min}$.

5.1.3.3.18. 29. HRMS (m/z): calcd for $\mathrm{C}_{36} \mathrm{H}_{46} \mathrm{dN}_{7} \mathrm{Na}_{2} \mathrm{O}_{11}, 478.1140\left([\mathrm{M}+2 \mathrm{Na}]^{2+}\right)$. Found 478.1141. HPLC (method C), $t_{\mathrm{R}} 4.78 \mathrm{~min}$. HPLC (method $\left.\mathrm{G}\right), t_{\mathrm{R}} 29.43 \mathrm{~min}$.

5.1.3.3.19. 30. HRMS $(\mathrm{m} / \mathrm{z})$ : calcd for $\mathrm{C}_{36} \mathrm{H}_{47} \mathrm{GdN}_{6} \mathrm{Na}_{2} \mathrm{O}_{10}, 463.6190\left([\mathrm{M}+2 \mathrm{Na}]^{2+}\right)$. Found 463.6187. HPLC (method A), $t_{\mathrm{R}} 4.02 \mathrm{~min}$. HPLC $(\operatorname{method} \mathrm{G}), t_{\mathrm{R}} 22.68 \mathrm{~min}$.

5.1.3.3.20. 34. HRMS (m/z): calcd for $\mathrm{C}_{42} \mathrm{H}_{52} \mathrm{GdN}_{9} \mathrm{Na}_{2} \mathrm{O}_{10} \mathrm{~S}, 539.1295\left([\mathrm{M}+2 \mathrm{Na}]^{2+}\right)$. Found 539.1293. HPLC (method A), $t_{\mathrm{R}} 3.26 \mathrm{~min}$. HPLC (method G), $t_{\mathrm{R}} 22.55 \mathrm{~min}$.

5.1.3.3.21. 35. HRMS $(\mathrm{m} / \mathrm{z})$ : calcd for $\mathrm{C}_{42} \mathrm{H}_{52} \mathrm{GdN}_{9} \mathrm{Na}_{2} \mathrm{O}_{11}, 531.1409\left([\mathrm{M}+2 \mathrm{Na}]^{2+}\right)$. Found 531.1412. HPLC (method A), $t_{\mathrm{R}} 3.18 \mathrm{~min} . \mathrm{HPLC}(\operatorname{method} \mathrm{G}), t_{\mathrm{R}} 21.96 \mathrm{~min}$.

5.1.3.3.22. 36. $\mathrm{HRMS}(\mathrm{m} / \mathrm{z})$ : calcd for $\mathrm{C}_{42} \mathrm{H}_{53} \mathrm{GdN}_{11} \mathrm{NaO}_{10} \mathrm{~S}, 542.1413\left([\mathrm{M}+\mathrm{H}+\mathrm{Na}]^{2+}\right)$. Found 542.1409. HPLC (method A), $t_{\mathrm{R}} 3.27 \mathrm{~min} . \mathrm{HPLC}(\operatorname{method} \mathrm{G}), t_{\mathrm{R}} 22.17 \mathrm{~min}$.

5.1.3.3.23. 37. $\mathrm{HRMS}(\mathrm{m} / \mathrm{z})$ : calcd for $\mathrm{C}_{42} \mathrm{H}_{59} \mathrm{GdN}_{9} \mathrm{NaO}_{11} \mathrm{~S}, 539.1591\left([\mathrm{M}+\mathrm{H}+\mathrm{Na}]^{2+}\right)$. Found 539.1582. HPLC (method A), $t_{\mathrm{R}} 4.08 \mathrm{~min}$. HPLC (method E), $t_{\mathrm{R}} 24.28-25.25 \mathrm{~min}$. HPLC (method G), $t_{\mathrm{R}}$ 24.67-25.40 min.

5.1.3.3.24. 38. $\mathrm{HRMS}(\mathrm{m} / \mathrm{z})$ : calcd for $\mathrm{C}_{42} \mathrm{H}_{58} \mathrm{GdN}_{9} \mathrm{NaO}_{12}, 1061.3338\left([\mathrm{M}+\mathrm{Na}]^{+}\right)$. Found 1061.3349. HPLC (method A), $t_{\mathrm{R}}$ 3.73-3.92 min. HPLC (method G), $t_{\mathrm{R}}$ 24.41-25.23 min.

5.1.3.3.25. 39. HRMS $(m / z)$ : calcd for $\mathrm{C}_{42} \mathrm{H}_{58} \mathrm{GdN}_{11} \mathrm{Na}_{2} \mathrm{O}_{11} \mathrm{~S}, 564.1536\left([\mathrm{M}+2 \mathrm{Na}]^{2+}\right)$. Found 564.1532. HPLC (method C), $t_{\mathrm{R}}$ 3.91-3.99 min. HPLC (method E), $t_{\mathrm{R}} 24.53-25.08 \mathrm{~min}$. HPLC (method G), $t_{\mathrm{R}}$ 25.01-25.44 min. 
5.1.3.3.26. 46. HRMS $(m / z)$ : calcd for $\mathrm{C}_{54} \mathrm{H}_{78} \mathrm{GdN}_{19} \mathrm{O}_{12} \mathrm{~S}, 687.2514\left([\mathrm{M}+2 \mathrm{H}]^{2+}\right)$. Found 687.2515. HPLC (method C), $t_{\mathrm{R}} 2.32 \mathrm{~min}$. HPLC (method G), $t_{\mathrm{R}} 20.63 \mathrm{~min}$.

5.1.3.3.27. 47. HRMS $(m / z)$ : calcd for $\mathrm{C}_{54} \mathrm{H}_{84} \mathrm{GdN}_{13} \mathrm{O}_{13} \mathrm{~S}, 656.2631\left([\mathrm{M}+2 \mathrm{H}]^{2+}\right)$. Found 656.2632. HPLC (method A), $t_{\mathrm{R}} 2.72 \mathrm{~min}$. HPLC (method E), $t_{\mathrm{R}}$ 20.47-20.66-20.80 min. HPLC $(\operatorname{method} \mathrm{F}), t_{\mathrm{R}}$ 13.67-14.05-14.31-14.82 min. HPLC (method G), $t_{\mathrm{R}} 19.05-19.25-19.35 \mathrm{~min}$. HPLC (method K), $t_{\mathrm{R}} 8.51-8.76-9.07-9.45 \mathrm{~min}$.

\subsection{HRMS $(\mathrm{m} / \mathrm{z})$ : calcd for $\mathrm{C}_{54} \mathrm{H}_{84} \mathrm{GdN}_{19} \mathrm{O}_{13} \mathrm{~S}, 698.2723\left([\mathrm{M}+2 \mathrm{H}]^{2+}\right)$. Found} 698.2729. HPLC (method A), $t_{\mathrm{R}} 2.80 \mathrm{~min} . \mathrm{HPLC}(\operatorname{method} \mathrm{E}), t_{\mathrm{R}} 21.12 \mathrm{~min} . \mathrm{HPLC}(\operatorname{method} \mathrm{G})$, $t_{\mathrm{R}} 20.83 \mathrm{~min}$.

5.1.3.3.29. 51. HPLC (method E), $t_{\mathrm{R}} 22.81 \mathrm{~min}$. HPLC (method $\left.\mathrm{J}\right), t_{\mathrm{R}} 18.75-18.84 \mathrm{~min}$.

5.1.3.3.30. 52. HRMS (negative mode) $(\mathrm{m} / \mathrm{z})$ : calcd for $\mathrm{C}_{45} \mathrm{H}_{58} \mathrm{GdN}_{10} \mathrm{O}_{22} \mathrm{~S}_{4}, 458.7290\left([\mathrm{M}-3 \mathrm{H}]^{3-}\right)$. Found 458.7273. HPLC (method E), $t_{\mathrm{R}} 18.79 \mathrm{~min} . \mathrm{HPLC}(\operatorname{method} \mathrm{J}), t_{\mathrm{R}} 16.15 \mathrm{~min}$.

\subsubsection{Quantification of free $G d^{3+}$ content}

Quantification of the non-chelated $\mathrm{Gd}^{3+}$, called the free $\mathrm{Gd}^{3+}$, was performed using a colorometric test with Arsenazo III. The glassware was previously cleaned with ethylenediaminetetraacetic acid (EDTA). The samples were prepared in a triethanolamine 1 $\mathrm{M} /$ nitric acid $0.5 \mathrm{M} 2: 3 \mathrm{pH} 7.85$ buffer containing Arsenazo III $\left(4.10^{-6} \mathrm{M}\right)$. The free $\mathrm{Gd}^{3+}$ concentration in the samples should not exceed $2 \cdot 10^{-6} \mathrm{M}$. The solutions were shaken for $30 \mathrm{~min}$ before measuring the absorbance $\left(654 \mathrm{~nm}, \varepsilon=34500 \mathrm{M}^{-1} \cdot \mathrm{cm}^{-1}\right)$. A standard curve with $\mathrm{GdCl}_{3}$ was used to determine the concentration of free $\mathrm{Gd}^{3+}$. 


\subsubsection{Quantification of total $\mathrm{Gd}^{3+}$ content}

$\mathrm{Gd}^{3+}$ content in the final compounds was measured by inductively coupled plasma-atomic emission spectroscopy (ICP-AES) (Optima 3300 RL, Perkin) or by inductively coupled plasmamass spectroscopy (ICP-MS) (Elan 6100 DRC plus, PerkinElmer) depending on the concentration of the sample. For this purpose, nitric acid $65 \%(4.5 \mathrm{~mL})$ was added to the gadolinium containing sample $(0.5 \mathrm{~mL})$. The mixture was heated at $80^{\circ} \mathrm{C}$ for $8 \mathrm{~h}$, allowing a complete dissolution of the Gd chelates. After the mineralization step, the sample was dissolved in MilliQ water to a final concentration of nitric acid at $32.5 \%$. Total $\mathrm{Gd}^{3+}$ concentration was quantified by ICP-AES or ICP-MS using a set of calibration standards ranking from $0.1 \mathrm{mg} / \mathrm{L}$ to $5 \mathrm{mg} / \mathrm{L}$ of $\mathrm{Gd}^{3+}$ with Yttrium as internal standard prepared in nitric acid 32.5\% (RF power at $1500 \mathrm{~W}, \mathrm{Gd}=342.257 \mathrm{~nm}, \mathrm{Y}=324,227 \mathrm{~nm}$ ), or ranking from $0.1 \mu \mathrm{g} / \mathrm{L}$ to $1200 \mu \mathrm{g} / \mathrm{L} \mathrm{of} \mathrm{Gd}{ }^{3+}$ with Indium as internal standard prepared in nitric acid $6.5 \%\left(\mathrm{RF}\right.$ power at $1300 \mathrm{~W},{ }^{157} \mathrm{Gd}^{+}$, ${ }^{115} \mathrm{In}^{+}$) respectively.

\subsection{Relaxivity measurements}

The free $\mathrm{Gd}^{3+}$ presents in the CA samples was measured before the relaxivity and biological studies. When free $\mathrm{Gd}^{3+}$ content exceeded $1 \%$ of the total $\mathrm{Gd}^{3+}$ contained in the sample, a correction on the relaxivity values obtained from the experiment was applied. Subtraction of the relaxation rate induced by the free $\mathrm{Gd}^{3+}\left(1 / \mathrm{T}_{\mathrm{i}(\mathrm{Gd})}, \mathrm{i}=1,2\right)$ to the measured relaxation rate $\left(1 / \mathrm{T}_{\mathrm{i}(\mathrm{mes})}\right)$ gave the intrinsic CA relaxivity $\left(\mathrm{r}_{\mathrm{CA}}\right)$ (Equation 1$)$. 
$\mathrm{r}_{\mathrm{CA}}=\left(1 / \mathrm{T}_{\mathrm{i}(\mathrm{mes})}-1 / \mathrm{T}_{\mathrm{i}(\mathrm{Gd})}\right) /\left(\left[\mathrm{Gd}^{3+}\right]_{(\mathrm{total})}-\left[\mathrm{Gd}^{3+}\right]_{(\mathrm{free})}\right)$

Equation 1. Correction applied on the measured relaxivity of the CAs containing more than $1 \%$ free $\mathrm{Gd}^{3+}$.

Water proton relaxation measurements were performed with a Bruker Minispec PC-20 relaxometer (Bruker, Wissembourg, France) at $20 \& 60 \mathrm{MHz}(0.47 \& 1.5 \mathrm{~T}), 37^{\circ} \mathrm{C}, \mathrm{pH} 7.4$, on solutions with a concentration of $\mathrm{Gd}(\mathrm{III})$ chelates ranging from 0.1 to $5 \mathrm{mM}$ in three different media (sterile water / ion cocktail ( $1 \mathrm{M}$ chloride, $25 \mathrm{mM}$ carbonate, $0.5 \mathrm{mM}$ phosphate and 0.2 $\mathrm{mM}$ citrate) / Seronorm Human ${ }^{\mathrm{TM}}$ ). Spin-lattice relaxation times, $\mathrm{T}_{1}$, and spin-spin relaxation times, $T_{2}$, were measured by inversion-recovery and CPMG method respectively. $r_{1}$ and $r_{2}$ were respectively calculated from the slope of the regression line of $1 / T_{1}$ or $1 / T_{2}$ against concentration with a least-squares method.

\subsection{Biological assays}

\subsubsection{Binding assays on $A \beta_{1-42}$ aggregates}

The solid form of peptide $A \beta_{1-42}$ was gently dissolved in $10 \mathrm{mM}$ sodium phosphate, $1 \mathrm{mM}$ EDTA, pH 7.4 sterile buffer $(50 \mu \mathrm{M})$. Aliquots $(200 \mu \mathrm{L})$ were frozen and stored at $-20{ }^{\circ} \mathrm{C}$ until their use. An aliquot of peptide was thawed and incubated for $36-42 \mathrm{~h}$ at $37{ }^{\circ} \mathrm{C}$ under gentle and constant shaking to induce the aggregation. The aggregated peptides were diluted with the buffer to $20 \mu \mathrm{M}$. The aggregated peptides $(20 \mu \mathrm{M}, 50 \mu \mathrm{L})$, the CA (40 $\mu \mathrm{L}$, DMSO, concentration range 0.3-1000 nM) and the $\left[{ }^{125} \mathrm{I}\right] \mathrm{IMPY}(1 \mathrm{nM}, 50 \mu \mathrm{L}$, ethanol 10\%) were diluted with ethanol $10 \%$ $(860 \mu \mathrm{L})$ and the mixture was incubated at $\mathrm{rt}$ for $3 \mathrm{~h}$ under gentle agitation. The mixture was then filtered through GF/B filters by using a Brandel M24 Harvester. The filters were washed with 
ethanol 10\% $(2 \times 3 \mathrm{~mL})$ and were collected to measure the radioactivity with a gamma-counter Cobra II. The amount of radioactivity retained on filter was determined through a control experiment without aggregated peptide. The software GraphPad Prism 4.02 was used to plot the specific binding of $\left[{ }^{125} \mathrm{I}\right] \mathrm{IMPY}$ against the logarithm concentration of the CA to determine the $\mathrm{IC}_{50}$ (quadruplicate). The $\mathrm{K}_{\mathrm{i}}$ of IMPY (homologous competition) was calculated from the $\mathrm{IC}_{50}$, using the following equation: $\mathrm{K}_{\mathrm{d}}=\mathrm{IC}_{50}-\mathrm{L}$. The $\mathrm{K}_{\mathrm{i}}$ of the CAs was calculated from the $\mathrm{IC}_{50}$, using the following equation: $\mathrm{K}_{\mathrm{i}}=\mathrm{IC}_{50} /[1+$ [radioligand $\left.] / \mathrm{K}_{\mathrm{d}}\right]$.

\subsubsection{Binding assays on human Alzheimer brain homogenates}

Postmortem brain tissues were obtained from four AD patients (Braak stage 4-6) and four agematched controls aged 67-90 at autopsy. Pre- and postmortem consents were obtained from next of kin, and brains were removed at autopsy, sectioned fresh and frozen at $-70{ }^{\circ} \mathrm{C}$. The cerebellum and the affected frontal cortex of $\mathrm{AD}$ patients together with the corresponding regions of the controls were dissected out. Homogenates were then prepared in PBS, pH 7.4, at the concentration of approximately $100 \mathrm{mg}$ wet tissue/mL (motor-driven glass homogenizer with setting of 6 for $30 \mathrm{~s})$. The homogenates were aliquoted $\left(1 \mathrm{~mL}\right.$ portions) and stored at $-70{ }^{\circ} \mathrm{C}$ for 3-6 months without loss of binding signal. Human Alzheimer brain homogenates $(25 \mu \mathrm{g} /$ well $)$ were incubated at $37{ }^{\circ} \mathrm{C}$ for 120 min with $\left[{ }^{125} \mathrm{I}\right] \mathrm{IMPY}(42 \mathrm{nM})$ in the absence or presence of the tested CA. The non-specific binding was measured in the presence of IMPY $(1 \mu \mathrm{M})$. Following incubation, the samples were rapidly filtered through GF/B glass fiber filters using a Packard cell harvester to separate the free radiolabeled ligand from that bound to the homogenates. The filters were dried and the retained radioactivity was quantified in a scintillation counter (Topcount, 
Packard) using a scintillation cocktail (Microscint 0, Packard). The data were treated with GraphPad Prism 4.02 (duplicate).

\subsubsection{BBB crossing assays}

These experiments were performed by the company PreCeM (LEMM group at iBiTech-S Institute, CEA Saclay, Gif-sur-Yvette, France). The in vitro BBB model used was constituted of a co-culture of rat primary brain capillary endothelial cells and rat glial cells supported by a polycarbonate filter $(0.4 \mu \mathrm{m})$. A solution of the CA in 4-(2-hydroxyethyl)-1piperazineethanesulfonic acid (HEPES) buffer $(10 \mu \mathrm{M})$ was introduced in the donor compartment (blood) and incubated at $37^{\circ} \mathrm{C}$ for $1 \mathrm{~h}$. The BBB permeation was determined by the quantification of the CA migration from the donor to the receiver (brain) compartments. The CA concentration was measured with ICP-MS. The experiments were performed in triplicate. The integrity and permeation of the BBB model was confirmed using sucrose and vinblastine.

\section{Supporting Information}

Tables which summarize the conditions used to synthesize each CA and synthon, as well as the HPLC and GC analytical methods used, the dose-response curves of the CA affinity study, the longitudinal and transversal relaxivity parameters measured at $20 \mathrm{MHz}$ and $60 \mathrm{MHz}$ in water, ion cocktail and seronorm, and the results of the BBB permeabily study. The ${ }^{1} \mathrm{H}$ and ${ }^{13} \mathrm{C}$ NMR signal attribution is also included. 


\section{Acknowledgment}

This work was financially supported by GUERBET group and the CNRS. The authors gratefully acknowledge Gerard Bourguine for his precious advices and support for the synthesis of the CAs. The authors are also very grateful to Prof. Alain Guy for his precious advices on the design and synthesis of the CAs.

\section{References}

[1] N. L. Batsch, M. S. Mittelman World Alzheimer Report 2012. London: Alzheimer's Disease International 2012, 1-80.

[2] R. Brookmeyer, E. Johnson, K. Ziegler-Graham, H. M. Arrighi, Forecasting the global burden of Alzheimer's disease, Alzheimers Dement. 3 (2007) 186-191.

[3] A. Nordberg, Amyloid plaque imaging in vivo: current achievement and future prospects, Eur. J. Nucl. Med. Mol. Imaging 35 (Suppl 1) (2008) S46-S50.

[4] D. M. Holtzman, J. C. Morris, A. M. Goate, Alzheimer's Disease: The Challenge of the Second Century, Sci. Transl. Med. 3 (2011) 77.

[5] Y. Huang, L. Mucke, Alzheimer Mechanisms and Therapeutic Strategies, Cell 148 (2012) 1204-1222.

[6] G. McKhann, D. Drachman, M. Folstein, R. Katzman, D. Price, E. M. Stadlan, Clinical diagnosis of Alzheimer's disease: report of the NINCDS-ADRDA Work Group under the auspices of Department of Health and Human Services Task Force on Alzheimer's Disease, Neurology 34 (1984) 939-944.

[7] B. Dubois, H. H. Feldman, C. Jacova, S. T. Dekosky, P. Barberger-Gateau, J. Cummings, A. Delacourte, D. Galasko, S. Gauthier, G. Jicha, K. Meguro, J. O'Brien, F. Pasquier, P. Robert, M. Rossor, S. Salloway, Y. Stern, P. J. Visser, P. Scheltens, Research criteria for the diagnosis of Alzheimer's disease: revising the NINCDS-ADRDA criteria, Lancet Neurol. 6 (2007) 734-746.

[8] J. A. Hardy, G. A. Higgins, Alzheimer's disease: the amyloid cascade hypothesis, Science 256 (1992) 184-185. 
[9] A. Nordberg, Amyloid imaging in early detection of Alzheimer's disease, Neurodegener. Dis. 7 (2010) 136-138.

[10] A. Nordberg, J. O. Rinne, A. Kadir, B. Långström, The use of PET in Alzheimer disease, Nat. Rev. Neurol. 6 (2010) 78-87.

[11] C. R. Jack Jr, D. S. Knopman, W. J. Jagust, L. M. Shaw, P. S. Aisen, M. W. Weiner, R. C. Petersen, J. Q. Trojanowski, Hypothetical model of dynamic biomarkers of the Alzheimer's pathological cascade, Lancet Neurol. 9 (2010) 119-128.

[12] A. Nordberg, Molecular imaging in Alzheimer's disease: new perspectives on biomarkers for early diagnosis and drug development, Alzheimer's Res. Ther. 3 (2011) 34.

[13] L. Cai, R. B. Innis, V. W. Pike, Radioligand development for PET imaging of betaamyloid (Abeta)--current status, Curr. Med. Chem. 14 (2007) 19-52.

[14] S. Furumoto, N. Okamura, R. Iwata, K. Yanai, H. Arai, Y. Kudo, Recent advances in the development of amyloid imaging agents, Curr. Top. Med. Chem. 7 (2007) 1773-1789.

[15] K.-L. Xiong, Q.-W. Yang, S.-G. Gong, W.-G. Zhang, The role of positron emission tomography imaging of [beta]-amyloid in patients with Alzheimer's disease, Nucl. Med. Commun. 31 (2010) 4-11.

[16] C. M. Clark, J. A. Schneider, B. J. Bedell, T. G. Beach, W. B. Bilker, M. A. Mintun, M. J. Pontecorvo, F. Hefti, A. P. Carpenter, M. L. Flitter, M. J. Krautkramer, H. F. Kung, R. E. Coleman, P. M. Doraiswamy, A. S. Fleisher, M. N. Sabbagh, C. H. Sadowsky, E. M. Reiman, S. P. Zehntner, D. M. Skovronsky, Use of florbetapir-pet for imaging $\beta$-amyloid pathology, JAMA 305 (2011) 275-283.

[17] A. Forsberg, H. Engler, O. Almkvist, G. Blomquist, G. Hagman, A. Wall, A. Ringheim, B. Långström, A. Nordberg, PET imaging of amyloid deposition in patients with mild cognitive impairment, Neurobiol. Aging 29 (2008) 1456-1465.

[18] A. Okello, J. Koivunen, P. Edison, H. A. Archer, F. E. Turkheimer, K. Nagren, R. Bullock, Z. Walker, A. Kennedy, N. C. Fox, M. N. Rossor, J. O. Rinne, D. J. Brooks, Conversion of amyloid positive and negative MCI to AD over 3 years, Neurology 73 (2009) 754-760.

[19] S. M. Landau, C. Breault, A. D. Joshi, M. Pontecorvo, C. A. Mathis, W. J. Jagust, M. A. Mintun, Amyloid- $\beta$ imaging with Pittsburgh Compound B and Florbetapir: comparing radiotracers and quantification methods, J. Nucl. Med. 54 (2013) 70-77. 
[20] C. C. Rowe, S. Ng, U. Ackermann, S. J. Gong, K. Pike, G. Savage, T. F. Cowie, K. L. Dickinson, P. Maruff, D. Darby, C. Smith, M. Woodward, J. Merory, H. Tochon-Danguy, G. O'Keefe, W. E. Klunk, C. A. Mathis, J. C. Price, C. L. Masters, V. L. Villemagne, Imaging betaamyloid burden in aging and dementia, Neurology 68 (2007) 1718-1725.

[21] M. A. Mintun, G. N. Larossa, Y. I. Sheline, C. S. Dence, S. Y. Lee, R. H. Mach, W. E. Klunk, C. A. Mathis, S. T. DeKosky, J. C. Morris, [11C]PIB in a nondemented population: potential antecedent marker of Alzheimer disease, Neurology 67 (2006) 446-452.

[22] K. E. Pike, G. Savage, V. L. Villemagne, S. Ng, S. A. Moss, P. Maruff, C. A. Mathis, W. E. Klunk, C. L. Masters, C. C. Rowe, Beta-amyloid imaging and memory in non-demented individuals: evidence for preclinical Alzheimer's disease, Brain 130 (2007) 2837-2844.

[23] H. J. Aizenstein, R. D. Nebes, J. A. Saxton, J. C. Price, C. A. Mathis, N. D. Tsopelas, S. K. Ziolko, J. A. James, B. E. Snitz, P. R. Houck, W. Bi, A. D. Cohen, B. J. Lopresti, S. T. DeKosky, E. M. Halligan, W. E. Klunk, Frequent Amyloid Deposition Without Significant Cognitive Impairment Among the Elderly, Arch. Neurol. 65 (2008) 1509-1517.

[24] E. C. Mormino, M. G. Brandel, C. M. Madison, G. D. Rabinovici, S. Marks, S. L. Baker, W. J. Jagust, Not quite PIB-positive, not quite PIB-negative: slight PIB elevations in elderly normal control subjects are biologically relevant, Neuroimage 59 (2012) 1152-1160.

[25] J. C. Morris, C. M. Roe, E. A. Grant, D. Head, A. M. Goate, A. M. Fagan, D. M. Holtzman, M. A. Mintun, Pittsburgh compound B imaging and prediction of progression from cognitive normality to symptomatic Alzheimer disease, Arch. Neurol. 66 (2009) 1469-1475.

[26] A. G. Vlassenko, M. A. Mintun, C. Xiong, Y. I. Sheline, A. M. Goate, T. L. S. Benzinger, J. C. Morris, Amyloid-beta plaque growth in cognitively normal adults: Longitudinal [11C]Pittsburgh compound B data, Ann. Neurol. 70 (2011) 857-861.

[27] J. L. Price, D. W. McKeel, V. D. Buckles, C. M. Roe, C. Xiong, M. Grundman, L. A. Hansen, R. C. Petersen, J. E. Parisi, D. W. Dickson, C. D. Smith, D. G. Davis, F. A. Schmitt, W. R. Markesbery, J. Kaye, R. Kurlan, C. Hulette, B. F. Kurland, R. Higdon, W. Kukull, J. C. Morris, Neuropathology of nondemented aging: Presumptive evidence for preclinical Alzheimer disease, Neurobiol. Aging 30 (2009) 1026-1036.

[28] D. E. Huddleston, S. A. Small, Technology Insight: imaging amyloid plaques in the living brain with positron emission tomography and MRI, Nat. Clin. Pract. Neuro. 1 (2005) 96105. 
[29] R. A. Yotter, J. Doshi, V. Clark, J. Sojkova, Y. Zhou, D. F. Wong, L. Ferrucci, S. M. Resnick, C. Davatzikos, Memory decline shows stronger associations with estimated spatial patterns of amyloid deposition progression than total amyloid burden, Neurobiol. Aging 34 (2013) 2835-2842.

[30] S. Aime, C. Cabella, S. Colombatto, S. Geninatti Crich, E. Gianolio, F. Maggioni, Insights into the use of paramagnetic Gd(III) complexes in MR-molecular imaging investigations, J. Magn. Reson. Imaging 16 (2002) 394-406.

[31] C. Corot, P. Robert, E. Lancelot, P. Prigent, S. Ballet, I. Guilbert, J.-S. Raynaud, I. Raynal, M. Port, Tumor imaging using P866, a high-relaxivity gadolinium chelate designed for folate receptor targeting, Magn. Reson. Med. 60 (2008) 1337-1346.

[32] J. Näslund, V. Haroutunian, R. Mohs, K. L. Davis, P. Davies, P. Greengard, J. D. Buxbaum, Correlation between elevated levels of amyloid $\beta$-peptide in the brain and cognitive decline, JAMA 283 (2000) 1571-1577.

[33] C. A. Mathis, Y. Wang, D. P. Holt, G. F. Huang, M. L. Debnath, W. E. Klunk, Synthesis and evaluation of 11C-labeled 6-substituted 2-arylbenzothiazoles as amyloid imaging agents, J. Med. Chem. 46 (2003) 2740-2754.

[34] A. F. Martins, J.-F. Morfin, C. F. G. C. Geraldes, É. Tóth, Gd(3+) complexes conjugated to Pittsburgh compound B: potential MRI markers of $\beta$-amyloid plaques, J Biol Inorg Chem 19 (2014) 281-295.

[35] Y. Z. Wadghiri, E. M. Sigurdsson, M. Sadowski, J. I. Elliott, Y. Li, H. Scholtzova, C. Y. Tang, G. Aguinaldo, M. Pappolla, K. Duff, T. Wisniewski, D. H. Turnbull, Detection of Alzheimer's amyloid in transgenic mice using magnetic resonance microimaging, Magn. Reson. Med. 50 (2003) 293-302.

[36] J. F. Poduslo, T. M. Wengenack, G. L. Curran, T. Wisniewski, E. M. Sigurdsson, S. I. Macura, B. J. Borowski, C. R. Jack, Molecular targeting of Alzheimer's amyloid plaques for contrast-enhanced magnetic resonance imaging, Neurobiol. Dis. 11 (2002) 315-329.

[37] J. F. Poduslo, G. L. Curran, J. A. Peterson, D. J. McCormick, A. H. Fauq, M. A. Khan, T. M. Wengenack, Design and chemical synthesis of a magnetic resonance contrast agent with enhanced in vitro binding, high blood-brain barrier permeability, and in vivo targeting to Alzheimer's disease amyloid plaques, Biochemistry 43 (2004) 6064-6075. 
[38] E. M. Sigurdsson, Y. Z. Wadghiri, L. Mosconi, J. A. Blind, E. Knudsen, A. Asuni, H. Scholtzova, W. H. Tsui, Y. Li, M. Sadowski, D. H. Turnbull, L. M. J. de, T. Wisniewski, A nontoxic ligand for voxel-based MRI analysis of plaques in AD transgenic mice, Neurobiol. Aging 29 (2008) 836-847.

[39] A. F. Martins, J.-F. Morfin, A. Kubíčková, V. Kubíček, F. Buron, F. Suzenet, M. Salerno, A. N. Lazar, C. Duyckaerts, N. Arlicot, D. Guilloteau, C. F. G. C. Geraldes, É. Tóth, PiBConjugated, Metal-Based Imaging Probes: Multimodal Approaches for the Visualization of $\beta$ Amyloid Plaques, ACS Med. Chem. Lett. 4 (2013) 436-440.

[40] J. Yang, Y. Z. Wadghiri, D. M. Hoang, W. Tsui, Y. Sun, E. Chung, Y. Li, A. Wang, L. M. de, T. Wisniewski, Detection of amyloid plaques targeted by USPIO-A $\beta 1-42$ in Alzheimer's disease transgenic mice using magnetic resonance microimaging, Neuroimage 55 (2011) 16001609.

[41] Y. Z. Wadghiri, J. Li, J. Wang, D. M. Hoang, Y. Sun, H. Xu, W. Tsui, Y. Li, A. Boutajangout, A. Wang, M. de Leon, T. Wisniewski, Detection of amyloid plaques targeted by bifunctional USPIO in Alzheimer's disease transgenic mice using magnetic resonance microimaging, PLoS ONE 8 (2013) e57097.

[42] W. E. Klunk, H. Engler, A. Nordberg, Y. Wang, G. Blomqvist, D. P. Holt, M. Bergström, I. Savitcheva, G. F. Huang, S. Estrada, B. Ausen, M. L. Debnath, J. Barletta, J. C. Price, J. Sandell, B. J. Lopresti, A. Wall, P. Koivisto, G. Antoni, C. A. Mathis, B. Långström, Imaging brain amyloid in Alzheimer's disease with Pittsburgh Compound-B, Ann. Neurol. 55 (2004) 306319.

[43] S. R. Choi, G. Golding, Z. Zhuang, W. Zhang, N. Lim, F. Hefti, T. E. Benedum, M. R. Kilbourn, D. Skovronsky, H. F. Kung, Preclinical properties of 18F-AV-45: a PET agent for Abeta plaques in the brain, J. Nucl. Med. 50 (2009) 1887-1894.

[44] N. Nelissen, K. Van Laere, L. Thurfjell, R. Owenius, M. Vandenbulcke, M. Koole, G. Bormans, D. J. Brooks, R. Vandenberghe, Phase 1 study of the Pittsburgh compound B derivative 18F-flutemetamol in healthy volunteers and patients with probable Alzheimer disease, J. Nucl. Med. 50 (2009) 1251-1259.

[45] C. C. Rowe, U. Ackerman, W. Browne, R. Mulligan, K. L. Pike, G. O'Keefe, H. TochonDanguy, G. Chan, S. U. Berlangieri, G. Jones, K. L. Dickinson-Rowe, H. P. Kung, W. Zhang, M. P. Kung, D. Skovronsky, T. Dyrks, G. Holl, S. Krause, M. Friebe, L. Lehman, S. Lindemann, L. 
M. Dinkelborg, C. L. Masters, V. L. Villemagne, Imaging of amyloid beta in Alzheimer's disease with 18F-BAY94-9172, a novel PET tracer: proof of mechanism, Lancet Neurol. 7 (2008) 129135.

[46] S. Nyberg, M. E. Jonhagen, Z. Cselenyi, C. Halldin, P. Julin, H. Olsson, Y. Freund-Levi, J. Andersson, K. Varnas, S. Svensson, L. Farde, Detection of amyloid in Alzheimer's disease with positron emission tomography using [11C]AZD2184, Eur. J. Nucl. Med. Mol. Imaging 36 (2009) 1859-1863.

[47] Y. Gravenfors, C. Jonasson, J. Malmstroem, G. Nordvall, D. Pyring, C. Slivo, D. Sohn, P. Stroem, D. Wensbo, Preparation of heteroarylbenzothiazoles for imaging of amyloid deposits and treatment of Alzheimer's disease, WO 2007086800.

[48] T. Kato, K. Ito, K. Hatano, A. Nakamura, N. Okamura, K. Yanai, [C-11]BF-227 PET imaging of amyloid deposition in AD, MCI, and normal subjects, J. Nucl. Med. 50 (Supp 2) (2009) 426.

[49] G. D. Rabinovici, W. J. Jagust, Amyloid imaging in aging and dementia: Testing the amyloid hypothesis in vivo, Behav. Neurol. 21 (2009) 117-128.

[50] W. E. Klunk, C. A. Mathis, The future of amyloid-beta imaging: a tale of radionuclides and tracer proliferation, Curr. Opin. Neurol. 21 (2008) 683-687.

[51] C. A. Mathis, Y. Wang, D. P. Holt, G. F. Huang, M. L. Debnath, W. E. Klunk, Synthesis and evaluation of 11C-labeled 6-substituted 2-arylbenzothiazoles as amyloid imaging agents, $\mathrm{J}$. Med. Chem. 46 (2003) 2740-2754.

[52] Z.-P. Zhuang, M.-P. Kung, C. Hou, K. Plossl, D. Skovronsky, T. L. Gur, J. Q. Trojanowski, V. M. Y. Lee, H. F. Kung, IBOX (2-(4'-dimethylaminophenyl)-6iodobenzoxazole): A ligand for imaging amyloid plaques in the brain, Nucl. Med. Biol. 28 (2001) 887-894.

[53] M.-P. Kung, C. Hou, Z.-P. Zhuang, D. Skovronsky, H. F. Kung, Binding of two potential imaging agents targeting amyloid plaques in postmortem brain tissues of patients with Alzheimer's disease, Brain Res. 1025 (2004) 98-105.

[54] H. F. Kung, C.-W. Lee, Z.-P. Zhuang, M.-P. Kung, C. Hou, K. Ploessl, Novel stilbenes as probes for amyloid plaques, J. Am. Chem. Soc. 123 (2001) 12740-12741. 
[55] N. P. Verhoeff, A. A. Wilson, S. Takeshita, L. Trop, D. Hussey, K. Singh, H. F. Kung, M. P. Kung, S. Houle, In-vivo imaging of Alzheimer disease beta-amyloid with [11C]SB-13 PET, Am. J. Geriat. Psychiat. 12 (2004) 584-595.

[56] R. Leuma Yona, S. Mazeres, P. Faller, E. Gras, Thioflavin derivatives as markers for amyloid-beta fibrils: insights into structural features important for high-affinity binding, ChemMedChem 3 (2008) 63-66.

[57] X. Chen, QSAR and primary docking studies of trans-stilbene (TSB) series of imaging agents for beta-amyloid plaques, J. Mol. Struct.: THEOCHEM 763 (2006) 83-89.

[58] Z.-P. Zhuang, M.-P. Kung, C. Hou, K. Ploessl, H. F. Kung, Biphenyls labeled with technetium 99m for imaging beta-amyloid plaques in the brain, Nucl. Med. Biol. 32 (2005) 171184.

[59] X. Chen, P. Yu, L. Zhang, B. Liu, Synthesis and biological evaluation of 99mTc, Remonoamine-monoamide conjugated to 2-(4-aminophenyl)benzothiazole as potential probes for beta-amyloid plaques in the brain, Bioorg. Med. Chem. Lett. 18 (2008) 1442-1445.

[60] M. Ono, R. Ikeoka, H. Watanabe, H. Kimura, T. Fuchigami, M. Haratake, H. Saji, M. Nakayama, Synthesis and evaluation of novel chalcone derivatives with $88 \mathrm{mTc} / \mathrm{Re}$ complexes as potential probes for detection of beta-amyloid plaques, ACS Chem. Neurosci. 1 (2010) 598-607.

[61] P. Caravan, J. J. Ellison, T. J. McMurry, R. B. Lauffer, Gadolinium(III) chelates as MRI contrast agents: structure, dynamics, and applications, Chem. Rev. 99 (1999) 2293-2352.

[62] S. Aime, M. Botta, S. Geninatti Crich, G. B. Giovenzana, G. Jommi, R. Pagliarin, M. Sisti, Synthesis and NMR Studies of Three Pyridine-Containing Triaza Macrocyclic Triacetate Ligands and Their Complexes with Lanthanide Ions, Inorg. Chem. 36 (1997) 2992-3000.

[63] J.-M. Idee, M. Port, C. Medina, E. Lancelot, E. Fayoux, S. Ballet, C. Corot, Possible involvement of gadolinium chelates in the pathophysiology of nephrogenic systemic fibrosis: A critical review, Toxicology 248 (2008) 77-88.

[64] C. Ferroud, H. Borderies, E. Lasri, A. Guy, M. Port, Synthesis of a novel amphiphilic GdPCTA-[12] derivative as a potential micellar MRI contrast agent, Tetrahedron Lett. 49 (2008) $5972-5975$.

[65] K. P. Eisenwiener, P. Powell, H. R. Mäcke, A convenient synthesis of novel bifunctional prochelators for coupling to bioactive peptides for radiometal labelling, Bioorg. Med. Chem. Lett. 10 (2000) 2133-2135. 
[66] D. F. Shi, T. D. Bradshaw, S. Wrigley, C. J. McCall, P. Lelieveld, I. Fichtner, M. F. Stevens, Antitumor benzothiazoles. 3. Synthesis of 2-(4-aminophenyl)benzothiazoles and evaluation of their activities against breast cancer cell lines in vitro and in vivo, J. Med. Chem. 39 (1996) 3375-3384.

[67] G. Bort, M. Sylla-Iyarreta Veitia, C. Ferroud, Straightforward synthesis of PET tracer precursors used for the early diagnosis of Alzheimer's disease through Suzuki-Miyaura crosscoupling reactions, Tetrahedron 69 (2013) 7345-7353.

[68] W. Zhang, S. Oya, M. P. Kung, C. Hou, D. L. Maier, H. F. Kung, F-18 stilbenes as PET imaging agents for detecting beta-amyloid plaques in the brain, J. Med. Chem. 48 (2005) 59805988.

[69] A. Benarab, S. Boye, L. Savelon, G. Guillaumet, Use of the cyanomethyl group as protecting group for phenols, amines and carbamates, Tetrahedron Lett. 34 (1993) 7567-7568.

[70] H. C. Brown, Y. M. Choi, S. Narasimhan, Selective reductions. 29. A simple technique to achieve an enhanced rate of reduction of representative organic compounds by borane-dimethyl sulfide, J. Org. Chem. 47 (1982) 3153-3163.

[71] A. Romieu, D. Brossard, M. Hamon, H. Outaabout, C. Portal, P.-Y. Renard, Postsynthetic derivatization of fluorophores with alpha-sulfo-beta-alanine dipeptide linker. Application to the preparation of water-soluble cyanine and rhodamine dyes, Bioconjugate Chem. 19 (2008) 279-289.

[72] S. L. Niu, G. Ulrich, R. Ziessel, A. Kiss, P.-Y. Renard, A. Romieu, Water-soluble BODIPY derivatives, Org. Lett. 11 (2009) 2049-2052.

[73] A. Lockhart, L. Ye, D. B. Judd, A. T. Merritt, P. N. Lowe, J. L. Morgenstern, G. Hong, A. D. Gee, J. Brown, Evidence for the Presence of Three Distinct Binding Sites for the Thioflavin T Class of Alzheimer's Disease PET Imaging Agents on $\beta$-Amyloid Peptide Fibrils, J. Biol. Chem. 280 (2005) 7677-7684.

[74] S. Aime, M. Botta, S. G. Crich, G. Giovenzana, R. Pagliarin, M. Sisti, E. Terreno, NMR relaxometric studies of Gd(III) complexes with heptadentate macrocyclic ligands, Magn. Reson. Chem. 36 (1998) S200-S208.

[75] G. M. Nicolle, E. Tóth, K.-P. Eisenwiener, H. R. Mäcke, A. E. Merbach, From monomers to micelles: investigation of the parameters influencing proton relaxivity, J. Biol. Inorg. Chem. 7 (2002) 757-769. 
[76] P. Caravan, Protein-targeted gadolinium-based Magnetic Resonance Imaging (MRI) contrast agents: design and mechanism of action, Acc. Chem. Res. 42 (2009) 851-862.

[77] B. Milton W, Morphology of blood-brain interfaces, Exp. Eye Res. 25 (1977) 1-25.

[78] F. Herve, N. Ghinea, J.-M. Scherrmann, CNS delivery via adsorptive transcytosis, AAPS J. 10 (2008) 455-472.

[79] S. Lundquist, M. Renftel, The use of in vitro cell culture models for mechanistic studies and as permeability screens for the blood-brain barrier in the pharmaceutical industryBackground and current status in the drug discovery process, Vascul. Pharmacol. 38 (2002) 355364.

[80] A. Reichel, D. Begley, N. J. Abbott, An Overview of In Vitro Techniques for BloodBrain Barrier Studies, in: The Blood-Brain Barrier, Ed. Nag, S., Humana Press, Toronto, 2003, Vol. 89, pp 307-324. 